
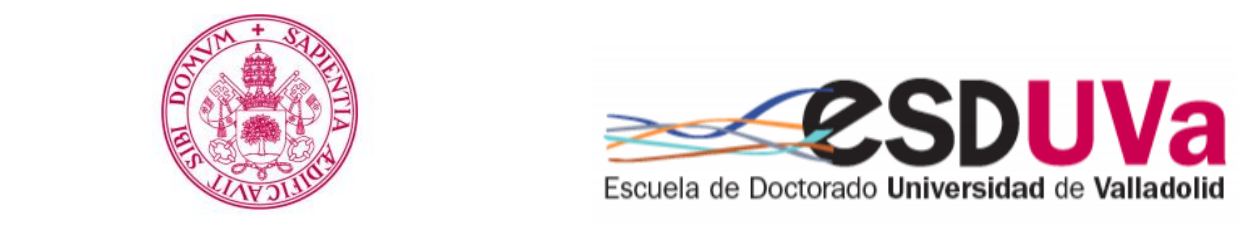

Universidad deValladolid

PROGRAMA DE DOCTORADO EN INGENIERÍA

TERMODINÁMICA DE FLUIDOS

TESIS DOCTORAL:

\title{
CARBON DIOXIDE HYDROGENATION BY MEANS OF PLASMONIC RESONANCE ACTIVATION
}

\author{
Presentada por Sergio Muñoz Palacios para \\ optar al grado de \\ Doctor por la Universidad de Valladolid
}

Dirigida por:

Alexander Navarrete Muñoz

Ángel Martín Martínez 



\title{
HIDROGENACIÓN DE DIÓXIDO DE CARBONO MEDIANTE ACTIVACIÓN POR RESONANCIA DE PLASMONES
}

\footnotetext{
Presentada por Sergio Muñoz Palacios para optar al grado de Doctor por la Universidad de Valladolid
}

\author{
Dirigida por:
}

Alexander Navarrete Muñoz Ángel Martín Martínez 

Universidad deValladolid

Memoria para optar al grado de Doctor, con Mención Doctor Internacional, presentada por el Ingeniero Químico:

Sergio Muñoz Palacios

Siendo el tutor en la Universidad de Valladolid:

Dr. Ángel Martín Martínez

Valladolid, Septiembre de 2018 



\title{
UNIVERSIDAD DE VALLADOLID \\ ESCUELA DE INGENIERÍAS INDUSTRIALES
}

\begin{abstract}
Secretaría
La presente tesis doctoral queda registrada en el folio número registro número del correspondiente libro de
\end{abstract}

Valladolid, a de de 2018

Fdo. El encargado del registro 



\author{
Alexander Navarrete Muñoz \\ Investigador \\ Karlsruhe Institute of Technology \\ Karlsruhe, Alemania \\ y
}

Ángel Martín Martínez

Profesor

Departamento de Ingeniería Química y Tecnología del Medio

Ambiente Universidad de Valladolid

Certifican que:

Sergio Muñoz Palacios ha realizado bajo su dirección el trabajo "Carbon dioxide hydrogenation by means of plasmonic resonance activation", en el Departamento de Ingeniería Química y Tecnología del Medio Ambiente de la Escuela de Ingenierías Industriales de la Universidad de Valladolid. Considerando que dicho trabajo reúne los requisitos para ser presentado como Tesis Doctoral expresan su conformidad con dicha presentación.

Valladolid, a de 2018 

Reunido el tribunal que ha juzgado la Tesis Doctoral titulada "Carbon dioxide hydrogenation by means of plasmonic resonance activation" presentada por Sergio Muñoz Palacios y en cumplimiento con lo establecido por el Real Decreto 99/2011 de 28 de enero de 2011 acuerda conceder por___ la calificación de

Valladolid, a de 2018 



\section{TABLE OF CONTENTS}

$\begin{array}{ll}\text { ABSTRACT } & 1\end{array}$

$\begin{array}{ll}\text { INTRODUCTION } & 7\end{array}$

$\begin{array}{lr}\text { OBJECTIVES } & 27\end{array}$

CHAPTER 1. A device for $\mathrm{CO}_{2}$ reduction using plasmonic catalyst activation 31

CHAPTER 2. Study of the influence of the reaction variables

CHAPTER 3. Enhanced light activation of the catalyst

CONCLUSIONS

99

$\begin{array}{ll}\text { RESUMEN (En castellano) } & 105\end{array}$

$\begin{array}{ll}\text { ACKNOWLEDGMENTS } & 131\end{array}$

$\begin{array}{ll}\text { ABOUT THE AUTHOR } & 137\end{array}$ 

ABSTRACT 

Climate change is the worst environmental problem that human race has faced and it is caused by the increase in greenhouse emissions. The combustion of fossil fuels with the aim of getting energy has resulted in a higher concentration of carbon dioxide in the atmosphere, with an increment of the global temperature. A warmer planet has a dramatic impact for the life of all organisms and future previsions are alarming.

Many actions have been proposed in order to cut down on carbon dioxide emissions. However, as fossil fuels are expected to be the main source of energy for the next years, a solution for the carbon dioxide produced must be found. The most promising alternative consists on transforming this carbon dioxide into products with high added value, which can make the process economically viable. Among the products obtained from carbon dioxide, methanol has attracted much attention because of its possible use as a fuel. Methanol could also work as energy storage if the $\mathrm{CO}_{2}$ conversion is carried out with solar energy. Performing this transformation with is still a challenge, mainly because of the low efficiency of the existing processes. New technologies are presently tested with the aim of enhancing the efficiency of the carbon dioxide hydrogenation in a scalable and sustainable manner.

In this thesis, a novel concept to perform the carbon dioxide hydrogenation by means of luminous energy has been proposed. A plasmonic microreactor device has been designed in order to integrate plasmon catalyst and reactor as one entity with a sole response to light. Copper nanoparticles deposited onto zinc oxide nanorods were initially chosen as catalyst due to their high selectivity and conversion in the production of methanol. At the same time, copper nanoparticles have shown surface plasmon resonance. This phenomenon increases the energy absorbed at given wavelengths for a specific size and shape of the nanoparticles. 
In order to perform the reaction in gas phase, a support was required for the catalyst. With the aim of ensuring that light reached correctly the nanoparticles to activate them, silica aerogels were chosen as a support due to their high transparency. They are mesoporous materials that provide high surface areas, which is also a property required in this work because it allows high loads of catalyst to perform the reaction.

The reaction was carried out in microreactors because they allow efficient mass and energy transference due to their large surface to volume ratio. They are also easily scalable and allow to work with small amount of reactants. The microreactors were made of glass with the purpose of maximising the absorption of light and as a consequence the efficiency of the process.

The proof-of-concept work was performed in Chapter I with the development of a new nanocomposite and its impregnation inside glass microreactors. With the aim of enhancing the light absorbed by the catalyst, a $\mathrm{Cu} / \mathrm{ZnO}$ catalyst was synthetized following a method proposed by Tan et al. (2013) that allowed the synthesis of discrete copper nanoparticles and its deposition onto zinc oxide nanorods. Light absorption of the synthetized catalyst was studied by UV-Vis spectrophotometry.

Mesoporous silica aerogels were produced following the sol-gel route. Tetramethyl orthosilicate was used as a precursor and the catalyst was introduced in a first step by creating a dispersion in methanol with sonication assistance. When all the reactants were mixed, the solution was liquid for a short time. This fact was used to impregnate the solution inside the microchannels using a syringe. After less than one minute, the gelation process took place and the hydrogel was formed directly inside the microchannels containing the catalyst inside its structure. After this, the hydrogels were aged for one week in methanol in order to remove all the water from the gel. Finally, the alcogels were 
dried using supercritical carbon dioxide to produce the aerogels. The result obtained were the silica aerogels with the catalyst loaded inside and showing great adherence to the walls of the glass microreactors. Silica aerogels were characterized by X-Ray Diffraction and BET analysis.

After the nanocomposite was correctly developed and characterized, an experimental setup was designed and built up. The installation allowed a precise control of carbon dioxide and hydrogen inlet flows, with a range of $0.1-1 \mathrm{ml} / \mathrm{min}$ of both gases. Pressure and temperature were also controlled and the system allowed to work between 1-50 bar and $20-180{ }^{\circ} \mathrm{C}$. Visual light was provided by 36 LEDs that were placed surrounding the microreactor to achieve the best light distribution throughout the reactor. A Micro Gas Chromatograph was used to measure the outlet gases and analyse the $\mathrm{CO}_{2}$ conversion.

When the experimental setup was ready, a proof of concept was made in order to test if it was possible to perform the reaction with the previously developed material. The power of white LEDs was applied and reactions changing flow and temperature were performed. The results obtained were stable in time during 300 minutes, showing that the concept proposed was possible and opening the possibility to improve the carbon dioxide transformation. The $\mathrm{CO}_{2}$ conversion rate achieves was around $381 \mathrm{mmol} / \mathrm{g}_{\mathrm{cat}} \cdot \mathrm{min}$.

In Chapter II, the influence of some reaction variables such as temperature, pressure, catalyst amount and reactants proportion was studied. First, reactions without connecting the LEDs were performed to prove that the reaction only took place under light activation. After that, a thorough experimental study of the influence of the reaction variables was performed. Changes in temperature and gases flow did not affect $\mathrm{CO}_{2}$ conversion rates, not being useful to improve the process. An increase in the amount of catalyst was negative for the goal of improving the $\mathrm{CO}_{2}$ conversion rate, achieving the best results for 
the smallest amount of catalyst. The key parameter to enhance the results has been proved to be the pressure. Increasing pressure up to 50 bar improved $\mathrm{CO}_{2}$ conversion rate from 381 to $389 \mathrm{mmol} / \mathrm{g}_{\text {cat }} \cdot \mathrm{min}$.

In Chapter III, the optimization of the process was made by the synthesis of a catalyst that absorbed a higher amount of energy from the light. In collaboration with researchers from Ikerbasque, a new method to synthesize copper nanoparticles deposited onto zinc oxide nanorods was proposed using hydrazine and ethylenglycol system to maximize the copper deposition and enhance the contact area between copper and zinc oxide. This improvement was measured by UV-Vis spectrophotometry to test the light absorbance of the new material. The bimetallic catalyst was loaded again in hydrophilic silica aerogels and impregnated in glass microreactors to perform the carbon dioxide hydrogenation. The pressure was studied as the key parameter to increase $\mathrm{CO}_{2}$ conversion rates with good results, achieving a higher rate of $1575 \mathrm{mmol} / \mathrm{g}_{\mathrm{cat}} \cdot \mathrm{min}$ at $50 \mathrm{bar}$.

As pressure was found to be the key parameter to improve the results, the last step was the modification of the experimental setup with the aim of working at higher pressures than 50 bar. A new flow controller for carbon dioxide was installed and the pressure range of the setup was increased up to 100 bar. With this new equipment, new experiments were performed in Chapter II and III to check if the results continued improving at higher pressures. The results obtained showed that carbon dioxide conversion rates were increased, particularly when supercritical conditions for carbon dioxide were reached. The best results were obtained for the new catalyst working at 100 bar with a $\mathrm{CO}_{2}$ conversion rate of $1932 \mathrm{mmol} / \mathrm{g}_{\mathrm{cat}} \cdot \mathrm{min}$, which means a five-fold increase compared with the first proof of concept. 


\section{INTRODUCTION}





\section{Environmental problem}

Global temperature of the planet has been increasing in the last years due to a phenomenon known as climate change. One of the main causes of climate change comes from greenhouse gases that are able to trap heat in the atmosphere ${ }^{1}$. When the sunlight reaches the Earth's land and oceans warming them, the surface radiates thermal infrared energy. This heat does not leave the planet directly, it is absorbed by greenhouse gases in the atmosphere and released gradually over time. This greenhouse effect is necessary for life in the planet, maintaining the temperature conditions avoiding freezing. However, the huge increase of the concentration of this gases in the atmosphere has broken the natural balance of the temperature in the planet keeping more heat than necessary. As a result, the global temperature has grown in the last years ${ }^{2}$ (Figure 1) and the tendency is to continue increasing in the next years.

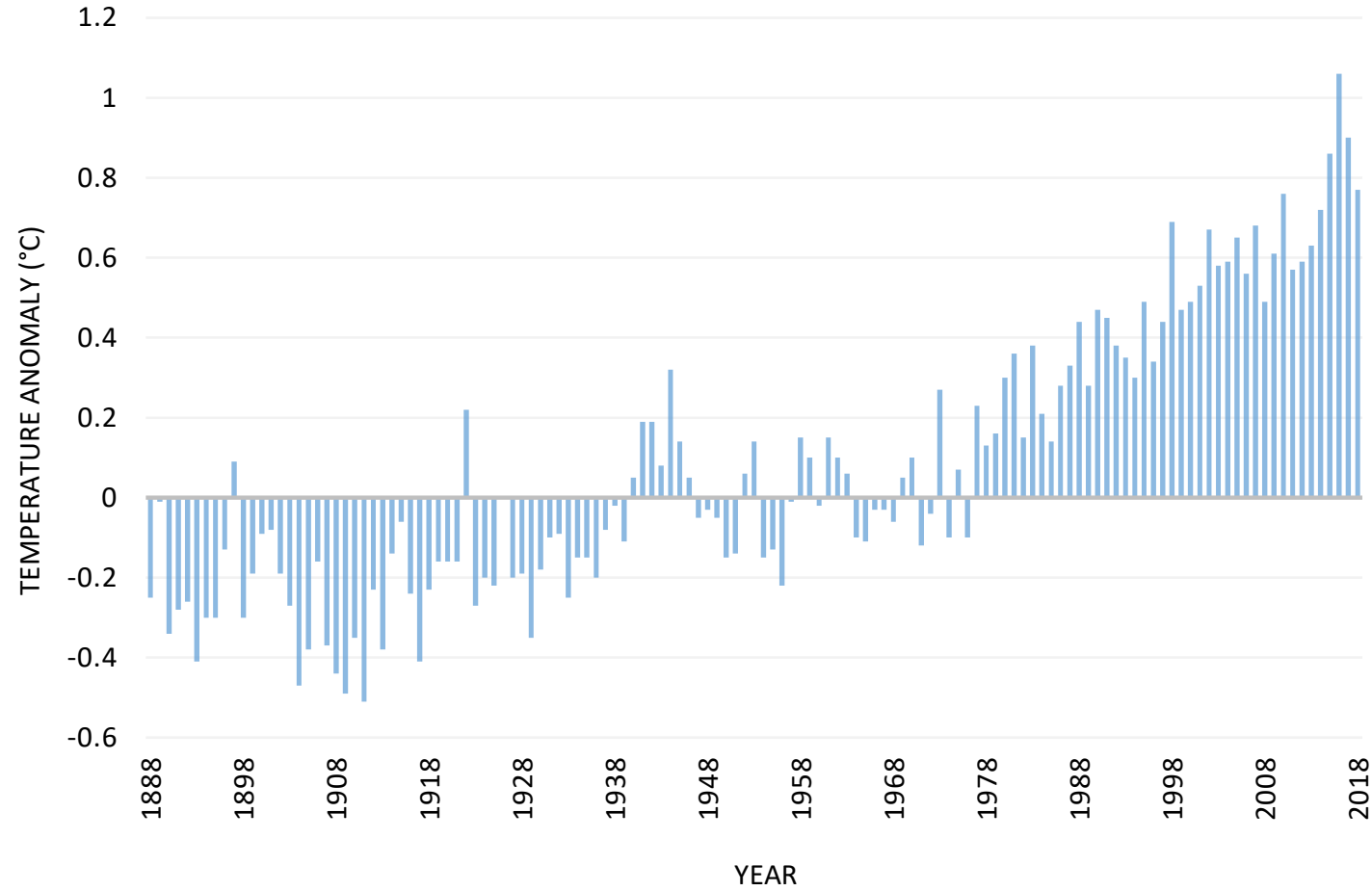

Figure 1. Global temperature anomalies respect to the $20^{\text {th }}$ century average (NOAA National Centers for Environmental information, Climate at a Glance: Global Time Series, 2018). 
Carbon dioxide, methane, nitrous oxide and fluorinated gases are considered as greenhouse gases. The importance of these gases in the greenhouse effect depends on how long they remain in the atmosphere, their concentration or abundance, and the strength of their impact ${ }^{3}$. Methane and nitrous oxide absorb more heat per molecule than carbon dioxide, although carbon dioxide remains much more time in the atmosphere and is more abundant. It is considered that carbon dioxide is the responsible of two-thirds of the increase in the heat retention, and the carbon dioxide absorption spectra corresponds with the upgoing thermal radiation that is not transmitted ${ }^{4}$ (Figure 2). This means that carbon dioxide emissions are the most important environmental problem that must be solved.

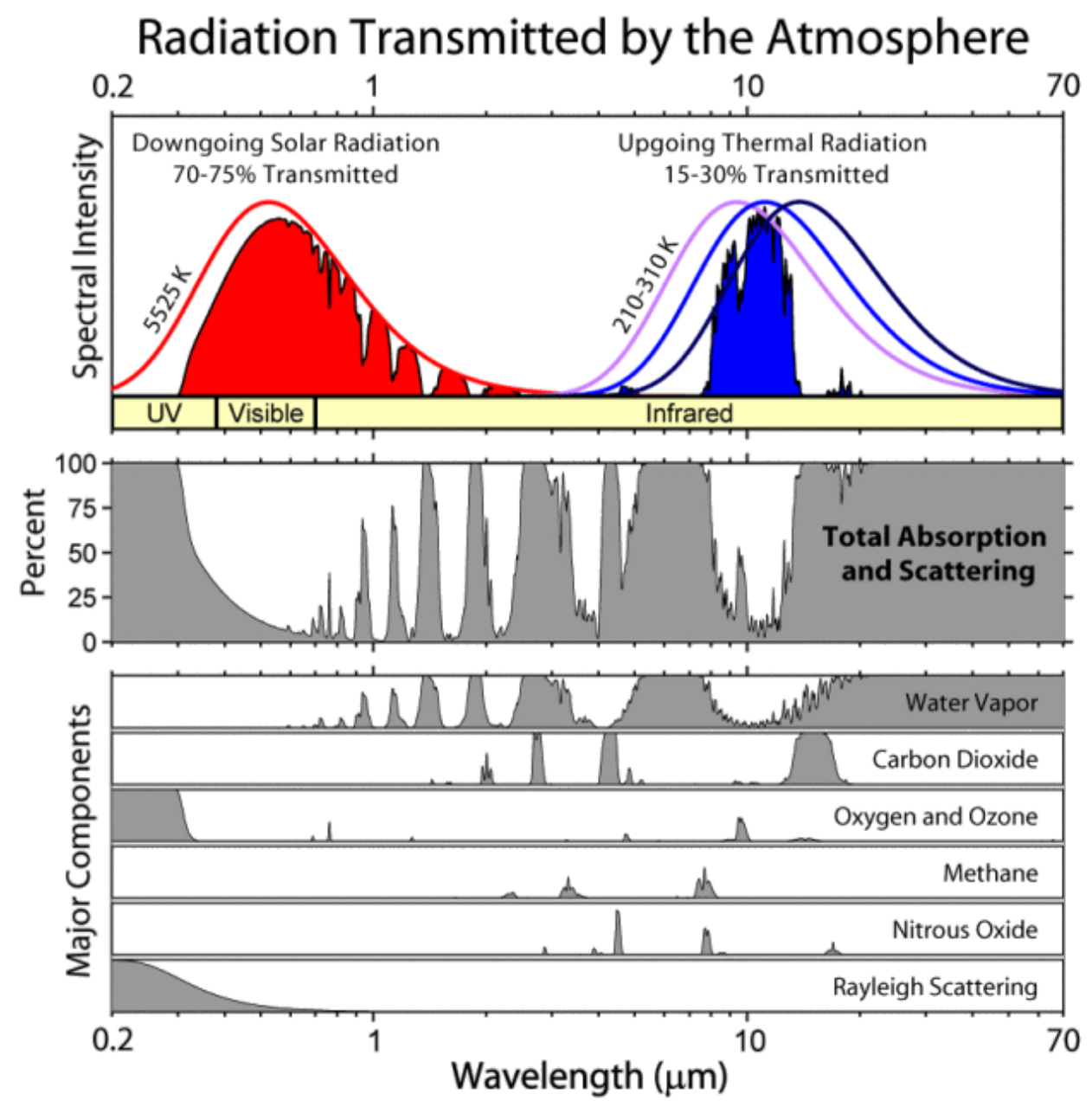

Figure 2. Radiation transmitted by the atmosphere (Smit et al., Introduction to carbon dioxide capture and sequestration, 2014). 
Carbon dioxide is a colourless and odourless molecule that appears in a gas state at ambient conditions. Carbon dioxide is a non-polar molecule, and it remains in the atmosphere because it is chemically unreactive at standard conditions ${ }^{5}$.

Carbon dioxide is generated by all aerobic organisms to produce energy by respiration, and it is a necessary compound for the growth of the plants. In this way, nature has acted as a regulator of carbon dioxide controlling its concentration in the atmosphere. However, the industrial revolution has led to an increase in the carbon dioxide emissions that nature cannot mitigate ${ }^{6}$. Nowadays, most of the emissions come from the combustion of fossil fuels to release energy that is commonly transformed into heat or electricity. On the other hand, carbon dioxide is used as a feedstock in some industrial processes, although this amount is low. As a result, carbon dioxide concentration has grown from $277 \mathrm{ppm}$ before industrial revolution to more than 402 nowadays (Figure 3), and this increase is expected to exceed $500 \mathrm{ppm}$ at the end of the century ${ }^{7}$.

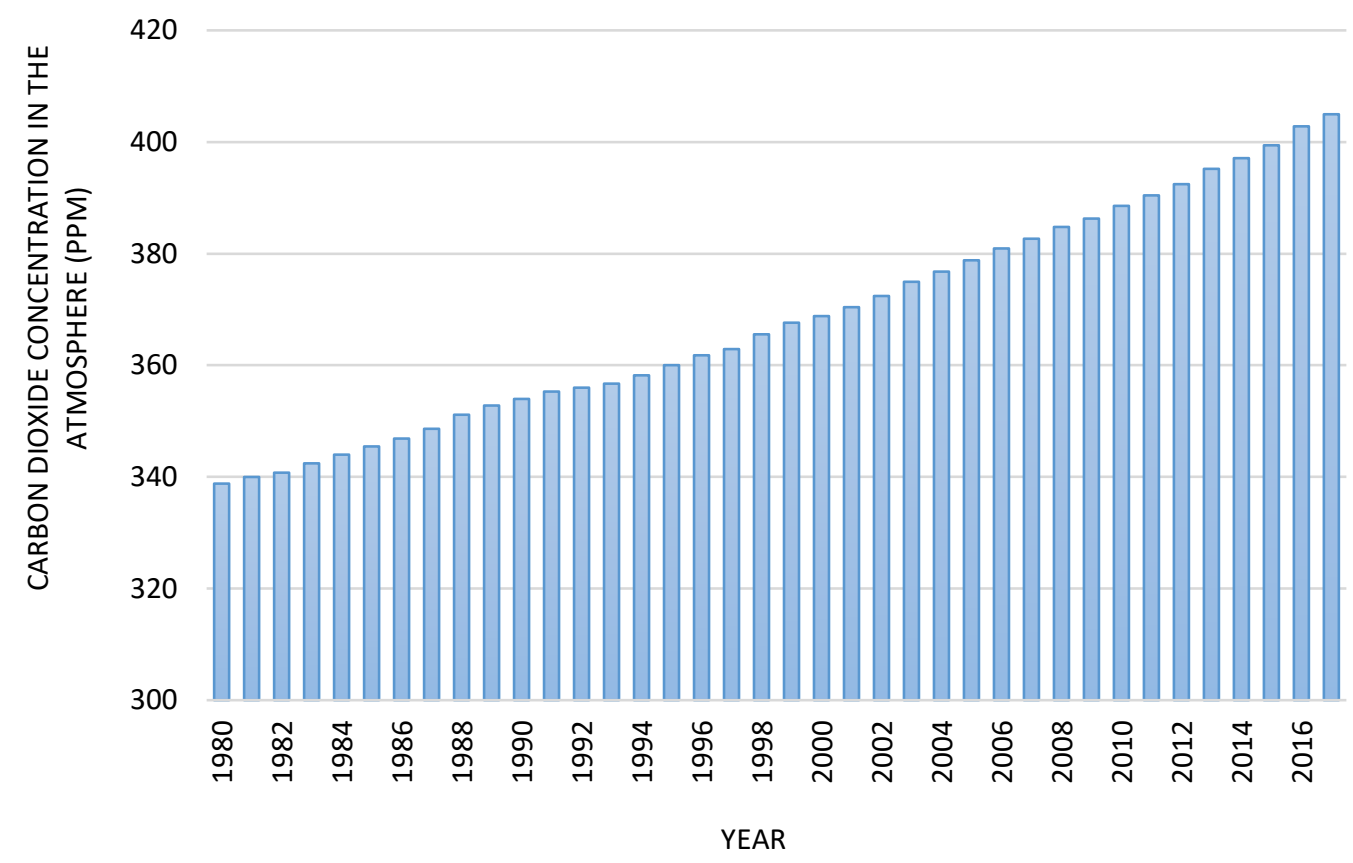

Figure 3. Evolution of carbon dioxide concentration in the atmosphere (Dlugokencky et al., NOAA/ESRL (www.esrl.noaa.gov/gmd/ccgg/trends/). 
The consequences of this increment in carbon dioxide emissions and the rise in global temperature are dramatic for the Earth. An important amount of this carbon dioxide has been absorbed by the oceans affecting their $\mathrm{pH}$. With higher carbon dioxide concentrations and higher temperature oceans are more acid than normal, affecting the organisms that live in them ${ }^{8}$. Also animals and plants that live in the Earth's surface are affected by this change that is expected to be the most important cause of species extinctions this century. Climate change is happenning so quickly that many species do not have enough time to adapt and they $\operatorname{die}^{9}$.

COP21 agreement in Paris was an important achievement in the fight against the climate change and is going to help in order to cut down on carbon dioxide emissions ${ }^{10}$. However, it is impossible to eliminate completely the carbon dioxide production from all the industrial and energy processes. For this reason, it is neccesary to find an alternative solution for the carbon dioxide produced.

\section{Carbon dioxide utilization}

Although fossil fuels are expected to continue being the main source of energy in the next years ${ }^{11}$, carbon dioxide emissions to the atmosphere could be reduced using new technologies. In this way, two possibilities have been proposed: the capture and storage or the use of carbon dioxide in different industrial processes (Figure 4). 


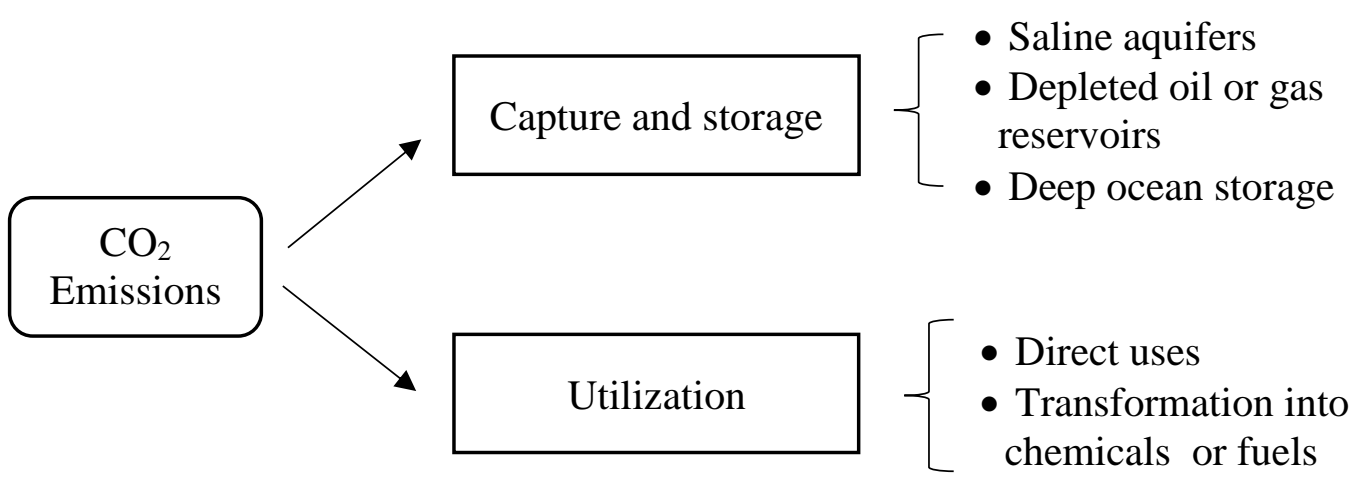

Figure 4. Possibilities to reduce carbon dioxide emissions to the atmosphere.

Many researchers have been focused on capture carbon dioxide efficiently and promising results have been obtained ${ }^{12,13}$. However, they are not still ready to manage huge amounts of carbon dioxide and the potential locations for its storage have not been decided nowadays because the safety of underground and ocean storage is still being studied.

On the other hand, carbon dioxide can also be used in the industry in two different ways: direct use or its conversion to chemicals. Among the direct uses, carbon dioxide has been commonly used in many industries such as soft drink, food, foaming or fire-extinguishers. It has been used as solvent in many processes in order to help in cleaning or separation. Carbon dioxide has been injected into depleted oil (enhanced oil recovery) and natural gas field (enhanced coal-bed methane) to increase the reservoir internal pressure which ultimately lead to the increase of the productivity ${ }^{14}$.

In the last few years, supercritical carbon dioxide has also attracted much attention due to its properties that allow its use in different ways. Supercritical Antisolvent (SAS) technology has been used for the encapsulation of different active compounds related with food, agricultural or pharmaceutical industries with different benefits compared with conventional encapsulation technologies ${ }^{15}$. The use of supercritical carbon dioxide as a 
medium for polymer synthesis and for polymer processing has shown some advantages. Particles from gas saturated solution (PGSS) technique is used to produce microparticles with different morphologies ${ }^{16}$. The production of new materials using supercritical carbon dioxide has allowed the development of new products such as aerogels ${ }^{17}$, which show remarkable properties that make them suitable for hydrogen storage ${ }^{18}$ or catalytic processes $^{19}$. However, the main use of supercritical carbon dioxide is found in the extraction of different compounds due to the use of lower temperatures that preserve the active compounds and the easier separation after the extraction. It has been used for the recovery of wine-must aroma compounds ${ }^{20}$, for the removal of 2, 4, 6 - tricholoroanisol from the cork stoppers of wine bottles ${ }^{21}$, or for the extraction of certain lipids ${ }^{22}$, among many examples.

Despite the multitude direct uses of carbon dioxide, the market of these processes is limited and its influence on the reduction of carbon dioxide is small. Because of it, carbon dioxide conversion to chemicals represents the best option due to the high potential market many products have, as it is shown in Table 1 . These products represent a good opportunity due to their global demand ${ }^{23}$.

Table 1. Some potential products from carbon dioxide as raw material. (Huang et al., Aerosol and Air Quality Research, 2014).

\begin{tabular}{|c|c|c|c|}
\hline Product & Reactants & $\begin{array}{c}\text { Potential of } \mathrm{CO}_{2} \\
\text { reduction (ton } \\
\mathrm{CO}_{2} / \text { ton of } \\
\text { product) }\end{array}$ & $\begin{array}{c}\text { Global } \\
\text { production }\end{array}$ \\
\hline Urea & $\mathrm{NH}_{3}$ and $\mathrm{CO}_{2}$ & 0.75 & $198.4 \mathrm{MT} / \mathrm{yr}$ \\
\hline Polycarbonate & $\mathrm{CO}_{2}$, Propylene oxide & 0.5 & $3.6 \mathrm{MT} / \mathrm{yr}$ \\
\hline Methanol & $\mathrm{CO}_{2}$ and $\mathrm{H}_{2}$ & 1.375 & $75 \mathrm{MT} / \mathrm{yr}$ \\
\hline Dimethyl carbonate & $\mathrm{CH}_{3} \mathrm{OH}$ and $\mathrm{CO}_{2}$ & 1.467 & $0.24 \mathrm{MT} / \mathrm{yr}$ \\
\hline Dimethyl ether & $\mathrm{CO}_{2}$ and $\mathrm{H}_{2}$ & 1.913 & $6.3 \mathrm{MT} / \mathrm{yr}$ \\
\hline
\end{tabular}


Among carbon dioxide possible transformations into chemicals, conversion into fuels have attracted most of the attention in the last few years ${ }^{24}$. The use of fossil fuels, that are the main source of energy nowadays, is limited in time because the reserves decrease every year ${ }^{25}$. The synthesis of energetic products from carbon dioxide would help to find an alternative source of energy for the future. The synthesis of fuels from carbon dioxide can be performed following several routes.

Carbon dioxide transformation using microalgae has been studied in the last years ${ }^{26}$. Microalgae are a polyphyletic group of unicellular photosynthetic eukaryotes that grow fast due to their simple structure. Microalgae have high potential as biodiesel feedstock because their oil content may exceed $70 \%(\mathrm{w} / \mathrm{wDW})$, as compared with $5 \%$ of the best agricultural oil crops ${ }^{27}$. They provide higher effectiveness of energy conversion because their metabolic functions demand less than other crops. The main problem is commonly to destroy the cell in order to extract the oil. Depending on the species of microalgae, they produce different kinds of hydrocarbons, lipids and other oils ${ }^{28}$. The optimization of their growth conditions can increase the oil concentration up to $80 \%$.

Electrochemical reduction of carbon dioxide is also a promising process to combine the utilization of carbon dioxide as feedstock and the storage of electric energy in a fuel ${ }^{29}$. Commonly, the electrochemical reduction transforms carbon dioxide into carbon monoxide, and is this second gas the precursor for the fuel synthesis ${ }^{30}$. The electrochemical reduction can also be performed to produce formic acid that is considered as a fuel too. The products synthesized depend on the applied conditions and electrode materials. 
However, the most common transformation of carbon dioxide into fuels is the hydrogenation. Hydrogen is a high energetic material that can be used to reduce carbon dioxide $^{31}$. The products obtained vary depending on the catalyst used and the pressure and temperatures conditions ${ }^{32}$ (Figure 5).

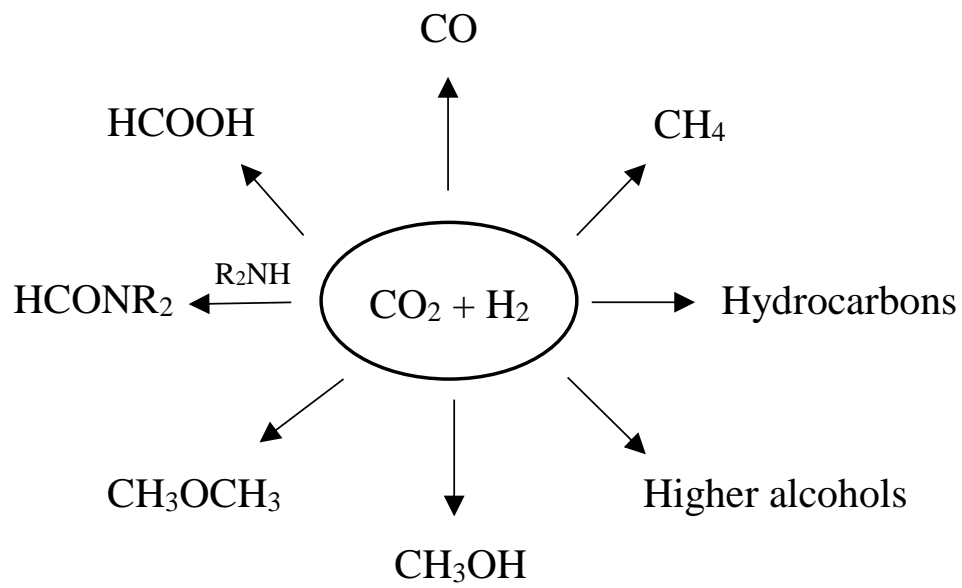

Figure 5. Different products obtained from carbon dioxide hydrogenation. (Wang et al., Chemical Society Reviews, 2011).

From a thermodynamic point of view, these reactions usually have a positive change of enthalpy and they are endothermic. The use of homogeneous and heterogeneous catalysts is widely extended to perform these reactions. Homogenous catalytic systems usually show higher catalytic activity than heterogeneous catalysts ${ }^{33}$. On the other hand, heterogeneous catalysts are better from the point of view of the reactor design, separation, handling, stability and reusability of the catalyst ${ }^{34}$. These advantages usually reduce the operation costs, which makes them the best option.

Among the different types of reactors, microreactors have shown many advantages that recommend their use in research scale. Their most important property is the high relation surface/volume provided ${ }^{35}$, which can be from 10000 to $50000 \mathrm{~m}^{2} / \mathrm{m}^{3}$. Conventional reactors used in laboratory provide around $1000 \mathrm{~m}^{2} / \mathrm{m}^{3}$, and industry reactors $100 \mathrm{~m}^{2} / \mathrm{m}^{3}$. 
This increment entails a better heat transfer efficiency, creating a more stable temperature profile along the reactor. In microreactors mass transport limitations are minimized, with a reduction of mixing times as a consequence. Other advantages are the possibility to work in continuous, the lower amount of reactants used and the improvement in the safety $^{36}$.

Methanol, formic acid or hydrocarbons are considered as potential fuels. We can find many studies concerning about the suitability of methanol for gasoline blends ${ }^{37}$, as well as concerning toxicology and environmental aspects of $\mathrm{MeOH}$ as a fuel. Methanol is a chemical commodity that is produced in the industry worlwide. It is produced performing a hydrogenation of carbon dioxide, where the catalysts used play an essential role in the selectivity of the reaction and the conversion achieved. Initially, the methanol synthesis from syngas was performed at $250-350$ bar and $350-450{ }^{\circ} \mathrm{C}$. In the 70 s the introduction of more active catalysts reduced these conditions down to $50-100$ bar and $200-300{ }^{\circ} \mathrm{C}$. The production of methanol from carbon dioxide can be performed in one single reaction. However, the conversion is increased when an intermediate step is included in order to produce first carbon monoxide which then reacts again with hydrogen to obtain methanol ${ }^{38}$.

$$
\begin{aligned}
& \mathrm{CO}_{2}+\mathrm{H}_{2} \Leftrightarrow \mathrm{CO}+\mathrm{H}_{2} \mathrm{O} ; \Delta H^{0}=+41.19 \mathrm{~kJ} / \mathrm{mol} \\
& \mathrm{CO}+2 \mathrm{H}_{2} \Leftrightarrow \mathrm{CH}_{3} \mathrm{OH} ; \Delta H^{0}=-90.70 \mathrm{~kJ} / \mathrm{mol}
\end{aligned}
$$

Many catalysts such as $\mathrm{Cu}, \mathrm{Ni}, \mathrm{Ru}, \mathrm{Pd}, \mathrm{Mo}$ or $\mathrm{CeO}_{2}$ have been studied in order to perform this reaction. Copper-based catalysts have been the most studied and they have shown the best results combined with other metals ${ }^{39}$. Coper has usually been mixed with different structures that acted as a support. The most extended combination has been $\mathrm{ZnO} / \mathrm{Cu}$ 
catalysts because the synergy created between both materials, achieved the highest selectivity to methanol ${ }^{40}$. Both are cheap and abundant materials, and their chemistry has been widely studied.

Current studies are focused on decreasing pressure and temperature conditions to carry out the reaction. The energy required for the reaction comes usually from burning fossil fuels, which limits the environmental application of this technology. Performing the carbon dioxide hydrogenation by means of renewable energies with good efficiencies is still a challenge and it is concentrating the research nowadays.

\section{Surface Plasmon Resonance}

Among renewable energies, many studies suggest that solar energy could be the most suitable choice to perform the reaction ${ }^{41}$. The use of solar energy to transform carbon dioxide is not new: plants show that this process can be carried out. In their case, carbon dioxide is transformed into glucose and oxygen using solar energy and water as a reactant (Figure 6).

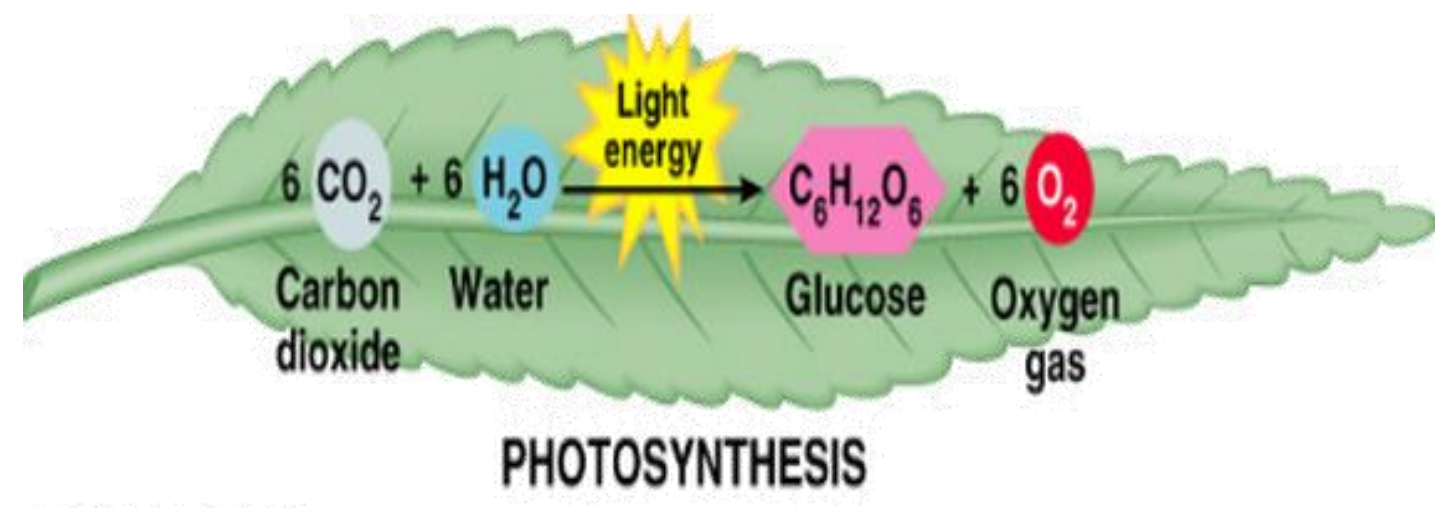

Figure 6. Photosynthesis reaction to obtain glucose and oxygen from carbon dioxide.

Artificial photosynthesis processes must be developed with the aim of copying this natural reaction. In 1972, Fujishima and Honda demonstrated the photoelectrochemical 
splitting of water using a $\mathrm{TiO}_{2}$ photoanode and a Pt cathode ${ }^{42}$. After this work, many studies have been carried out in the development of photocatalytic $\mathrm{CO}_{2}$ conversion systems ${ }^{43,44}$. The main problem of photocatalytic processes is the low efficiency due to the insufficient use of all the energy from the sun. Most of the investigations have focused on semiconductor materials such as $\mathrm{TiO}_{2}$ due to their chemical stability ${ }^{45}$. However, semiconductor materials absorb light in the ultraviolet band, which represents only about a $4 \%$ of the light spectrum. Because of it, many researchers work in different technologies with the aim of improving the efficiency of the photocatalytic processes.

The field of improvement consists on incorporating visible absorption of the light to this material. Some studies have been done working in the surface photosensitization ${ }^{46}$, although the most promising route is the combination with noble metals. It has been shown that noble metal nanoparticles such as gold or silver improve the photocatalytic activity of $\mathrm{TiO}_{2}$ in a higher scale than other materials ${ }^{47}$. This enhancement is due to a phenomenon called surface plasmon resonance that increases the energy absorbed in the visible band by these nanoparticles.

Surface plasmon resonance was first demonstrated by Otto in $1968^{48}$, although it was used before unintentionally by humans. Its application started in the 90 s by the company Biacore for healthcare, and nowadays it is extended to different fields such as spectroscopy ${ }^{49}$, sensing ${ }^{50}$ and photocatalysis ${ }^{51}$. It is known that the intensity of the light absorption and the wavelength where it takes place depend on the size and shape of the metallic nanoparticles ${ }^{52,53}$ (Figure 7). In the field of photocatalysis, this property opens the possibility to design different catalysts where the light absorption is tuneable. 

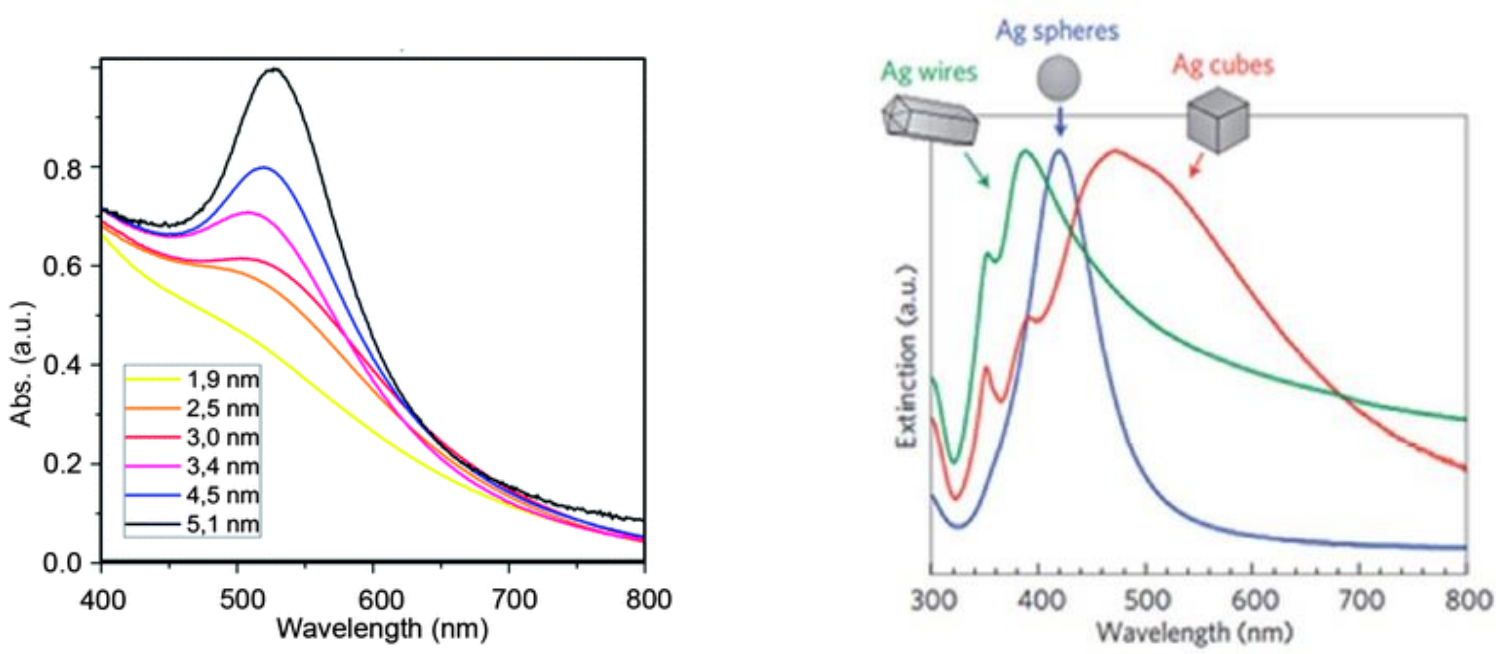

Figure 7. Light absorption of gold depending on the size of the nanoparticles (left) and light absorption of silver depending on the shape of the nanoparticles (right) (Nealon et al., Nanoscale, 2012; Valenti, et al., Journal of Materials Chemistry A, 2016).

Noble metal nanoparticles have free conduction band electrons that oscillate induced by the light radiation. When the oscillation frequency of light magnetic field is in accordance with that of free electrons, they start to oscillate. The surface plasmon polarization consists on magnetic waves that are propagated along the interface between materials with positive and negative permittivities, as it occurs in the intersection between a dielectric and a metal ${ }^{54}$. This effect only takes place when the size of the nanoparticles is much smaller than the wavelength of the light. Metals that have shown this effect are silver, gold, copper, aluminium, sodium and indium. The surface of the semiconductor or dielectric material must be free of other substances that can prevent the formation of the interface semiconductor - noble metal.

Surface plasmon resonance has been recently started to be used in the field of photocatalysis, mainly with gold and silver nanoparticles. However, this effect in copper nanoparticles has been less studied and there is an unexplored field to enhance reactions using them, such as carbon dioxide hydrogenation. The use of surface plasmon resonance 
with copper nanoparticles represents a possibility to reduce the temperature conditions required for the hydrogenation and a way to improve the efficiency of the light energy storage in methanol form.

\section{References}

1. Marland, G., Rotty, R.M., Greenhouse gases in the atmosphere: what do we know. Journal of the Air Pollution Control Association, 1985, 35 (10), 1033 - 1038.

2. NOAA National Centers for Environmental information, Climate at a Glance: Global Time Series, published July 2018, from https://www.ncdc.noaa.gov/cag/.

3. Montzka, S.A., Dlugokencky, E.J., Butler, J.H., Non- $\mathrm{CO}_{2}$ greenhouse gases and climate change. Nature, 2011, 476 (7358), 43 - 50.

4. Smit, B., et al., Introduction to carbon dioxide capture and sequestration (book). The Berkeley Lectures on Energy, 2014, 1.

5. Joshi, P. B., Carbon dioxide utilization: A comprehensive review. International Journal of Chemical Sciences, 2014, 12 (4), 12081220.

6. Le Quéré, C., et al., Global Carbon Budget 2017, Earth System Science Data, 2018, 10(1), 405-448.

7. Dlugokencky, E., Tans, P., NOAA/ESRL (www.esrl.noaa.gov/gmd/ccgg/trends/).

8. Guinotte, J.M., Fabry, V.J., Ocean acidification and its potential effects on marine ecosystems. Annals of the New York Academy of Sciences, 2008, 1134, 320 -342.

9. Garnier, J., Lewis, M.A., Expansion under climate change: The genetic consequences. Bulletin of Mathematical Biology, 2016, 78 (11), 2165 - 2185.

10. Christoff, P., The promissory note: COP 21 and the Paris Climate Agreement. Environmental Politics, 2016, 25 (5), 765 - 787.

11. York, R., Do alternative energy sources displace fossil fuels? Nature Climate Change, 2012, 2 (6), $441-443$.

12. D’Alessandro, D.M., Smit, B., Long, J.R., Carbon dioxide capture: Prospects for new materials. Angewandte Chemie - International Edition, 2010, 49 (35), 6058 - 6082. 
13. Leung, D.Y.C., Caramanna, G., Maroto-Valer, M.M., An overview of current status of carbon dioxide capture and storage technologies. Renewable and Sustainable Energy Reviews, 2014, 39, 426 - 443.

14. Norhasyima, R.S., Mahlia, T.M.I., Advances is $\mathrm{CO}_{2}$ utilization technology: A patent landscape review. Journal of $\mathrm{CO}_{2}$ Utilization, 2018, 26, 323 - 335.

15. Arango-Ruiz, A., et al., Encapsulation of curcumin using supercritical antisolvent (SAS) technology to improve its stability and solubility in water. Food Chemistry, 2018, 258, $156-163$.

16. Labuschagne, P. W., Naicker, B., Kalombo, L., Micronization, characterization and in-vitro dissolution of shellac from PGSS supercritical $\mathrm{CO}_{2}$ technique. International Journal of Pharmaceutics, 2016, 499, 205 - 216.

17. Fricke, J., Aerogels - highly tenuous solids with fascinating properties. Journal of Non-Crystalline Solids, 1988, 100 (1-3), 169 - 173.

18. Rueda, M. et al., Improvement of the kinetics of hydrogen release from ammonia borane confined in silica aerogel. Microporous and Mesoporous Materials, 2017, 237, $189-200$.

19. Wang, C.-T., Ro, S.-H., Nanocluster iron oxide-silica aerogel catalysts for methanol partial oxidation. Applied Catalysis A: General, 2005, 285 (1-2), 196 - 204.

20. Macedo, S., et al., Recovery of wine-must aroma compounds by supercritical $\mathrm{CO}_{2}$. Food Bioprocess Technology, 2008, 1, $74-81$.

21. Viguera, M. et al., The parameters that affect the supercritical extraction of 2,4,6trichloroanisol from cork. Journal of Supercritical Fluids, 2018.

22. Sahena F., et al., Application of supercritical $\mathrm{CO}_{2}$ in lipid extraction - A review. Journal of food engineering, 2009, 95, 240 - 253.

23. Huang, C.-H., Tan, C.-S., A review: $\mathrm{CO}_{2}$ Utilization. Aerosol and Air Quality Research, 2014, 14 (2), 480 - 499.

24. Aresta, M., Dibenedetto, A., Angelini, A., The changing paradigm of $\mathrm{CO}_{2}$ utilization. Journal of $\mathrm{CO}_{2}$ Utilization, 2013, 3-4, 65 - 73. 
25. Vernon, C., Thompson, E., Cornell, S., Carbon dioxide emission scenarios: limitations of the fossil fuel resource. Procedia Environmental Sciences, 2011, 6, 206 -215 .

26. Adeyeni, O.M., Azimov, U., Burluka, A., Algae biofuel: Current status and future applications. Renewable and Sustainable Energy Reviews, 2018, 90, 316 - 335.

27. Malcata, F.X., Microalgae and biofuels: A promising partnership?. Trends in Biotechnology, 2011, 29 (11), 542 - 549.

28. Kleinová, A., et al., Biofuels from algae. Procedia Engineering, 2012, 42, 231 - 238.

29. Hegner, R., Rosa, L.F.M., Harnisch, F., Electrochemical $\mathrm{CO}_{2}$ reduction to formate at indium electrodes with high efficiency and selectivity in $\mathrm{pH}$ neutral electrolytes. Applied Catalysis B: Environmental, 2018, 238, 546 - 556.

30. Costentin, C., Robert, M., Savéant, J.-M., Catalysis of the electrochemical reduction of carbon dioxide. Chemical Society Reviews, 2013, 42(6), 2423 - 2436.

31. Federsel, C., Jackstell, R., Beller, M., State-of-the-art catalysts for hydrogenation of carbon dioxide. Angewandte Chemie - International Edition, 2010, 49 (36), 6254 6257.

32. Wang, W., et al., Recent advances in catalytic hydrogenation pf carbon dioxide. Chemical Society Reviews, 2011, 40 (7), 3703 - 3727.

33. Wesselbaum, S., et al., Hydrogenation of carbon dioxide to methanol by using a homogeneous ruthenium-phosphine catalyst. Angewandte Chemie - International Edition, 2012, 51 (30), 7499 - 7502.

34. Dang, S., et al., A review of research progress on heterogeneous catalysts for methanol synthesis from carbon dioxide hydrogenation. Catalysis Today, 2018.

35. Salmi, T. O., Mikkola, J.-P., Warna, J. P., Chemical reaction engineering and reactor technology (book). Chemical Industries, 2011, 125.

36. Illg, T., Löb, P., Hessel, V., Flow chemistry using milli- and microstructured reactors. From conventional to novel process windows. Bioorganic and Medicinal Chemistry, 2010, 18 (11), 3707 - 3719. 
37. Yanju, W., et al., Effects of methanol/gasoline blends on a spark ignition engine performance and emissions. Energy and Fuels, 2008, 22 (2), 1254 - 1259.

38. Joo, O.-S., et al., Carbon dioxide hydrogenation to form methanol via a reverse-watergas-shift traction (the CAMERE process). Industrial and Engineering Chemistry Research, 1999, 38 (5), 1808 - 1812.

39. Natesakhawat, S. et al., Active sites and structure-activity relationships of copperbased catalysts for carbon dioxide hydrogenation to methanol. ACS Catalysis, 2012, 2 (8), $1667-1676$.

40. Burch, R., Chappell, R.J., Golunski, S.E., Synergy between copper and zinc oxide during methanol synthesis. Transfer of activating species. Journal of the Chemistry Society, Faraday Transactions 1: Physical Chemistry in Condensed Phases, 1989, 85 (10), 3569 -3578.

41. Aresta, M., Dibenedetto, A., Angelini, A., The use of solar energy can enhance the conversion of carbon dioxide into energy-rich products: Stepping towards artificial photosynthesis. Philosophical Transactions of the Royal Society A: Mathematical, Physical and Engineering Sciences, 2013, 371 (1996), 0111.

42. Fujishima, A., Honda, K., Electrochemical photolysis of water at a semiconductor electrode. Nature, 1972, 238, 37 - 38.

43. Yaron, P. Application of $\mathrm{TiO}_{2}$ photocatalysis for air treatment: patent's overview. Applied Catalysis B: Environmental, 2010, 99, 448 - 460.

44. Li, X., et al., Photocatalytic reduction of $\mathrm{CO}_{2}$ over noble metal-loaded and nitrogendoped mesoporous $\mathrm{TiO}_{2}$. Applied Catalysis A, 2012, 429-430, 31 - 38 .

45. Schneider, J., et al., Understanding $\mathrm{TiO}_{2}$ photocatalysis: Mechanisms and materials (Review). Chemical Reviews, 2014, 114 (19), 9919 - 9986.

46. Islam, A., Sugihara, H., Arakawa, H., Molecular design of ruthenium (II) polypyridyl photosensitizers for efficient nanocrystalline TiO2solar cells. Journal of Photochemistry and Photobiology A: Chemistry, 2003, 158 (2-3), 131 - 138. 
47. Liu, E. et al., Photocatalytic reduction of $\mathrm{CO} 2$ into methanol over $\mathrm{Ag} / \mathrm{TiO}_{2}$ nanocomposites enhanced by surface plasmon resonance. Plasmonics, 2014, 9, 61 70.

48. Maier, S.A., Plasmonics: Fundamentals and applications (Book), 2007, 1 - 223.

49. Willets, K.A., Van Duyne, R.P., Localized Surface plasmon resonance: spectroscopy and sensing. Annual Review of Physical Chemistry, 2007, 58, 267 - 297.

50. Wei, W., et al., Graphene/Au - enhanced plastic clad silica fiber optic surface plasmon resonance sensor. Plasmonics, 2018, 13 (2), 483 - 491.

51. Wu, T., et al., Surface plasmon resonance-induced visible light photocatalytic reduction of graphene oxide: Using Ag nanoparticles as a plasmonic photocatalyst. Nanoscale, 2011, 3 (5), 2142 - 2144.

52. Nealon, G.L., et al., Magnetism in gold nanoparticles. Nanoscale, 2012, 4 (17), 5244 -5258 .

53. Valenti, M., et al., Plasmonic nanoparticle-semiconductor composites for efficient solar water splitting. Journal of Materials Chemistry A, 2016, 4 (46), 17891 - 17912.

54. Saryche, A.K., Shets, G., Shalaev, V.M., Magnetic plasmon resonance. Physical Review E- Statistical, Nonlinear, and Soft Matter Physics, 2006, 73 (3), 036609. 

OBJECTIVES 

Many processes have been proposed in order to transform carbon dioxide into different products and help to mitigate climate change by decreasing carbon dioxide emissions. Among them, transformation into fuels offers an added value to the process, opening the possibility to make the transformation economically viable. Carbon dioxide hydrogenation produces methanol which is considered as a fuel with a high global demand.

In this work, light energy is proposed to be the only source of energy used to perform the reaction avoiding the use of fossil fuels to obtain the energy required for the reaction and the subsequent carbon dioxide production. Different catalysts have been studied in the field of photocatalysis, although the efficiencies of the processes are still low. Some technologies have tried to improve the light absorption of the catalysts, and surface plasmon resonance has been shown to be a useful alternative to increase the energy absorbed in the visible band.

The general aim of this work is to perform the hydrogenation of carbon dioxide by means of light energy. In order to achieve this general goal, several specific objectives must be developed:

- Synthesis of catalysts and supports that enhance the conversion of $\mathrm{CO}_{2}$ by means of light energy. This objective involves the development of a catalytic system composed by noble metal nanoparticles able to show the surface plasmon resonance effect, and a transparent support with high surface area that allows light to reach the nanoparticles inside and activate the catalyst.

- Design and construction of an experimental setup to perform the reaction, providing a precise control of the operational parameters (from inlet gases flow to temperature and 
pressure), and a method to analyze the gas outlet in line. Special emphasize will be given to the reactor, developing a procedure to impregnate glass microreactors homogeneously with the synthesized catalysts, as well as to conceive a light-emitting diode assembly able to illuminate the entire reactor, providing light in the most homogeneous way possible.

- Performance of a proof of concept with the aim of demonstrating that the idea is technically viable and carbon dioxide hydrogenation by means of light energy can be carried out with good results. After that, the optimization of the process will be investigated by improving the light absorbed by the catalyst, or by the study of the influence of the reaction variables in the carbon dioxide transformation. 


\section{CHAPTER 1}

\section{A device for $\mathrm{CO}_{2}$ reduction using plasmonic catalyst activation}





\section{Introduction}

\section{1. $\mathrm{CO}_{2}$ as a renewable energy vector}

One of the most industrially promising heterogeneous catalytic processes is carbon dioxide hydrogenation. In the process of catalytic hydrogenation, hydrogen obtained from carbon neutral energy sources (e.g. wind or solar) is reacted with $\mathrm{CO}_{2}$ to obtain products such as fuels ${ }^{1}$. Thus, this process will then serve a double purpose: first, as a chemical storage of the surplus energy generated by the fluctuating renewable energies; and second, to reduce the emissions of $\mathrm{CO}_{2}$.

Successful introduction of the $\mathrm{CO}_{2}$-use technologies require of plausible and profitable processes that use efficiently renewable energy. The most abundant and evenly distributed of such energies is the one provided by sun. If stored in the form of "solar commodities" such as methanol or olefins new opportunities for use of $\mathrm{CO}_{2}$ could be opened ${ }^{2}$. The production of methanol from $\mathrm{CO}_{2}$ and hydrogen involves the following reactions:

$$
\begin{aligned}
& \mathrm{CO}_{2}+\mathrm{H}_{2} \Leftrightarrow \mathrm{CO}+\mathrm{H}_{2} \mathrm{O} ; \Delta H^{0}=+41.19 \mathrm{~kJ} / \mathrm{mol} \\
& \mathrm{CO}+2 \mathrm{H}_{2} \Leftrightarrow \mathrm{CH}_{3} \mathrm{OH} ; \Delta H^{0}=-90.70 \mathrm{~kJ} / \mathrm{mol} \\
& \mathrm{CO}_{2}+3 \mathrm{H}_{2} \Leftrightarrow \mathrm{CH}_{3} \mathrm{OH}+\mathrm{H}_{2} \mathrm{O} ; \Delta H^{0}=-49.51 \mathrm{~kJ} / \mathrm{mol}
\end{aligned}
$$

In order to capture that energy in chemical bonds there are several useful methods for reactions. From the chemical point of view, they can be grouped into photocatalytic, thermal and electrical routes. In electrical routes, the solar energy is first converted into 
electricity and then, the resultant electrical energy is used in the chemical transformations of $\mathrm{CO}_{2}{ }^{3-7}$; the thermal routes concentrate the solar radiation and convey that energy directly into the reactor ${ }^{8-10}$. Photocatalytic $\mathrm{CO}_{2}$ conversion involves either the water splitting connected to a $\mathrm{CO}_{2}$ reduction reaction, or a process combining both in one "single pot"11-13.

\subsection{Selective use of visual light with plasmon catalysts}

Surface Plasmon Resonance (SPR) phenomenon is commonly found in metallic (or carbon) nanostructures and allows to increase the range of the solar spectrum used on a given photoinduced process ${ }^{14}$. This effect is the result of the response of the conduction electrons to the oscillations of the electric field of the light radiation. An increased energy absorption by the electrons is possible at selected wavelengths under the proper particle size and shape of the nanoparticles for a given surrounding media (fluid or catalyst). This phenomenon produces high light concentration up to the point that a reduction in the amount of semiconductor of three orders of magnitude for the same amount of light has been possible ${ }^{15}$. On the other hand, increased light capture with SPR for photothermal conversions are leading to breakthroughs in energy systems such solar collectors ${ }^{16}$.

This work explores the reduction of $\mathrm{CO}_{2}$ to $\mathrm{CO}$ as a first step in a solar-based process to produce methanol. Thus, it is based on the Reverse Water Gas Shift (RWGS) reaction as described by the equation (1). Recent approaches have used gold and semiconductor composites for plasmonic enhancement of the reduction ${ }^{17,18}$.

Yet, this process is commonly activated in industry using $\mathrm{Cu} / \mathrm{ZnO}$ based catalysts ${ }^{19}$. Here, plasmonic catalytic composites in mesoporous silica structures (Aerogels) have 
been developed. For this, the plasmon-tuneable $\mathrm{Cu} / \mathrm{ZnO}$ catalyst reported by Tan et al. $(2013)^{20}$ has been used.

\subsection{A plasmonic microreactor as a light harvesting device}

The efficiency of the chemical reactions is not ruled only by the catalytic material but also for the reactor configuration and their mass and energy transport characteristics. Many times promising catalytic materials fail to reach industrial success owing to the disconnection between the catalytic structure and the reactor-level phenomena ${ }^{21,22}$.

In this work, it is proposed a novel concept for visual energy harvesting: a plasmonic microreactor device. It integrates plasmon catalyst, and reactor as one entity with a sole response to light (Figure 1.1).

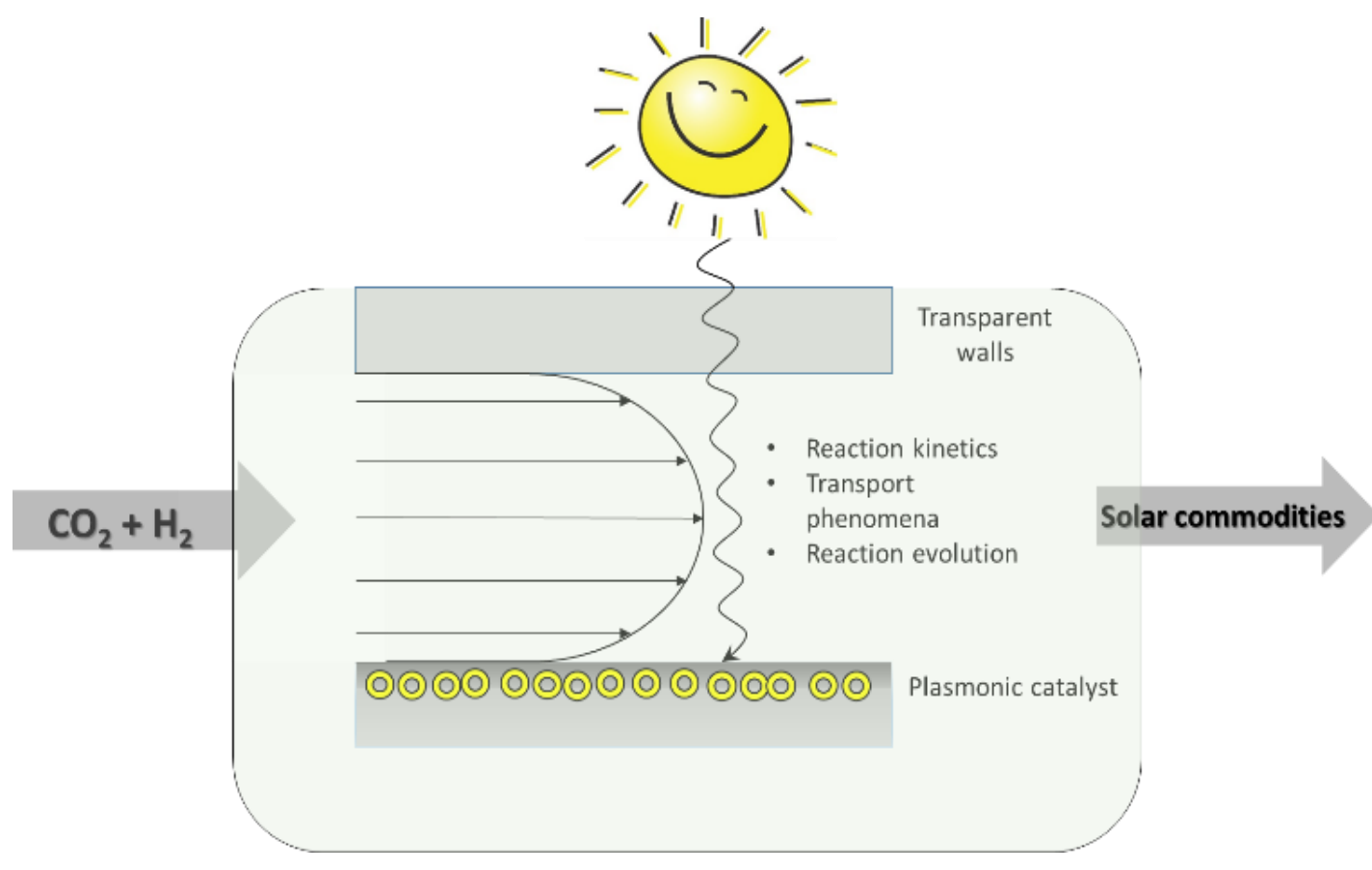

Figure 1.1. Concept of the plasmonic microreactor device.

Microreactors allow efficient energy and mass transport while are easily scalable (numbering up). Thus, the combination of efficient microstructured devices and direct 
plasmonic absorption of solar energy by the catalyst would represent a major breakthrough in the $\mathrm{CO}_{2}$-use field.

During this work, a plasmon-tuneable composite is integrated with a microchannel based reaction system under visual LED illumination for the RWGS reaction. This has involved the synthesis of the new composite; the development of an impregnation method to create a catalyst-reactor entity; finally, the assembly of a reaction system to test the reaction.

\section{Methods}

\subsection{Plasmo-catalytic composites synthesis}

The chemicals used during this stage are detailed: Zinc acetate dihydrate $(>98 \%)$, oleylamine (70\%), tetramethyl orthosilicate (98\%), ammonia (28-30\%), triethylenglicol (99\%) were purchased from Sigma-Aldrich. Ethylenglicol (99.5\%) (Merck). Copper acetate monohydrate (99.9\%) was purchased from Alfa Aesar. Methanol $(99.8 \%)$ (Panreac). All chemicals were used without further purification.

\subsection{Synthesis of $\mathrm{Cu} / \mathrm{ZnO}$ bimetallic catalyst}

This bimetallic $(\mathrm{Cu}: \mathrm{ZnO}, 1: 2)$ catalyst was synthesised following the procedure proposed by Tan et al $(2013)^{20}$.

Briefly, first $\mathrm{ZnO}$ nanorods were prepared. Zinc acetate $(3 \mathrm{mmol})$ was added to $1.3 \mathrm{mmol}$ of oleylamine in a two necked flask. The oleylamine has not a high purity (70\%), requiring a step where the reactants were degassed at $80{ }^{\circ} \mathrm{C}$ for $45 \mathrm{~min}$ in vacuum atmosphere. Then, the temperature was increased to $220{ }^{\circ} \mathrm{C}$ under nitrogen purging. During the heating process, the solution turns white upon reaching $180^{\circ} \mathrm{C}$. After $15 \mathrm{~min}$ of heating, the mixture was cooled to atmospheric temperature, washed with ethanol and 
centrifuged in order to isolate the precipitate. It was washed with $6 \mathrm{ml}$ of ethanol three times to ensure complete removal of the reactants or byproducts.

$\mathrm{ZnO}$ nanorods prepared above were then redispersed in $20 \mathrm{ml}$ of triethylenglicol by sonication for two hours, followed by stirring under room conditions overnight. Ethylenglicol (2ml) was added to the $\mathrm{ZnO}$ dispersion, and the mixture was degassed at room temperature for $5 \mathrm{~min}$ before heating to $190{ }^{\circ} \mathrm{C}$. Simultaneously, a second solution of copper acetate monohydrate was prepared dissolving in ethylenglicol. This mixture required sonication in order to dissolve well the copper acetate in the liquid. This mixture was added to the $\mathrm{ZnO}$ mixture in a dropwise manner during $10 \mathrm{~min}$. After this, $5 \mathrm{~min}$ more at $190{ }^{\circ} \mathrm{C}$ were allowed before the composite was washed with isopropanol, centrifuged during 15 minutes at 4500rpm (centrifuge Kubota 5100, Japan) and isolated from the mixture.

\subsection{Synthesis of mesoporous silica composites}

Light transmission to the catalytic structures is essential while enough surface area has to be provided in order to have enough metal loads to capture light. Transparent aerogels are mesoporous materials combining high surface areas and good light transmission ${ }^{23}$.

Aerogels were synthesised following the sol-gel route. The precursor for the silica hydrogel selected was the tetramethyl orthosilicate (TMOS). The molar ratio TMOS: $\mathrm{CH}_{3} \mathrm{OH}: \mathrm{H}_{2} \mathrm{O}: \mathrm{NH}_{4}$, was $1: 2.3: 3.84: 0.012$.

First, methanol was used to disperse the nanoparticles formed in the catalyst synthesis. Sonication (15 min) was applied to ensure a good dispersion of the nanoparticles in the liquid phase. Methanol with the particles and TMOS were mixed together. While this solution was stirred, a second solution of ammonium hydroxide and water was prepared 
and stirred. After a few minutes of stirring, both solutions were mixed, and the gelation process began. In this moment, the gelation process of the silica hydrogel has started, but it is still liquid for a few minutes. This time lapse, before gelation, must be used to impregnate the solution inside the microchannels of the microreactors.

\subsection{Integration of composites and microreactor}

In order to have a single integrated device it is necessary to integrate light transmission and composite activation in the same structure. Here, we have developed a method to integrate transparent aerogels in glass microchannels. The method used to make the impregnation of the sol-gel that showed best results was the suction of the liquid with a syringe, which was previously adapted to the microreactor on its top (Figure 1.2). With this method, placing the microreactor in vertical position, it was very easy to fill the microchannel placing the tip in the liquid. After a short time, the gelation process finished and the hydrogel formed had a good adherence inside the microchannels.

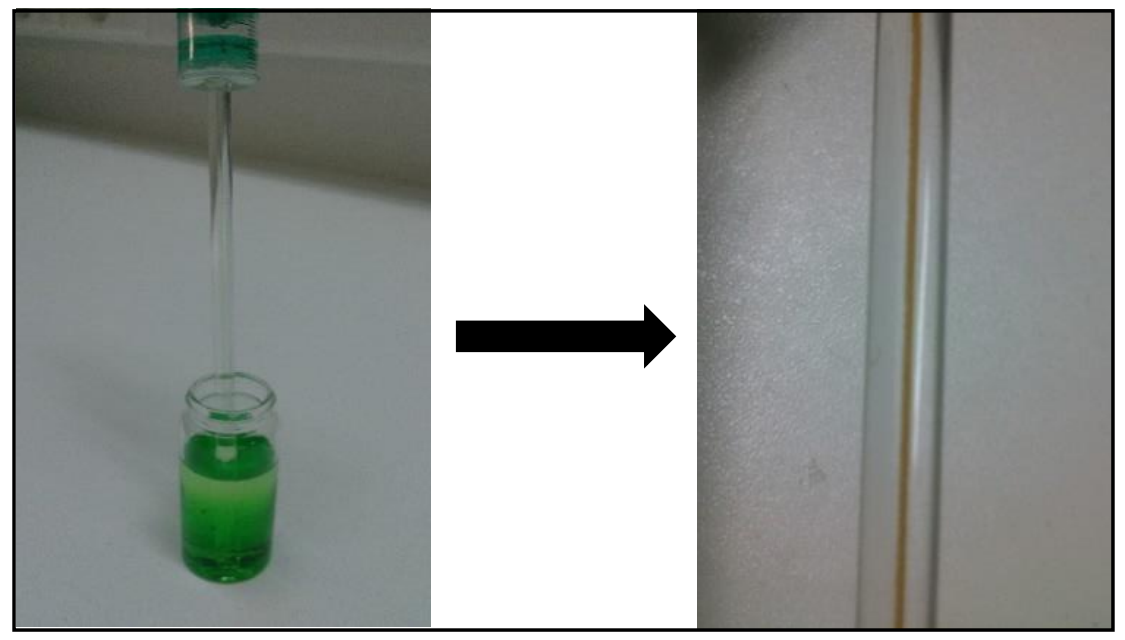

Figure 1.2. Syringe filling microchannels.

It is worth to mention that one of the most important parameters during this step is the amount of ammonia, as it acts as the catalyst for the gelation process. It is necessary to 
use an amount of ammonia low enough that allows to have enough time to impregnate the hydrogel inside the microreactor, because it must be still a fluid. On the other hand, the amount of ammonia cannot be very low, because if the gelation process is too slow, the nanoparticles start to precipitate and they will not be inside the silica net. Finding an equilibrium between this two factors is the key to achieve a good impregnation of the nanoparticles supported in the silica gels inside the microreactors.

In order to ensure a good adherence of the aerogel to the walls of the microchannels, it is necessary to perform a pre-treatment to the glass microreactors $(15.0 \mathrm{~cm})$ to clean the walls of the microchannels. For this cleaning process, the most common option is to use a piranha solution, which reacts violently with most organic materials. The solution used was a mixture of sulfuric acid and hydrogen peroxide that can be prepared in different proportions, the most usual 4:1 in concentrated sulfuric acid. From 15 to 30 minutes the material is submerged in the solution, then removed, washed with plenty Milli-Q water and dried carefully.

The empty glass microreactors were put inside a glass pot, and the sulfuric acid was first added. Then, the hydrogen peroxide was also added with extreme care because the reaction is very exothermic, the temperature is suddenly increased and some vapours can be formed. After 20 minutes, the slides were removed from the piranha solution, washed with Milli-Q water and dried carefully.

After introduction of the nanoparticles in the sol-gel and its introduction into the microreactors, these were put in a vessel with methanol for aging. This vessel was carefully closed to avoid methanol evaporation, and it was heated to $50{ }^{\circ} \mathrm{C}$ in an oven. With this procedure the water contained in the silica net was replaced with methanol, 
resulting into alcogels. After 24 hours of heating, the alcogels were dried using supercritical carbon dioxide. The microreactors were put in a high pressure vessel, and this vessel was filled completely with methanol. Carbon dioxide was introduced slowly in the vessel to allow a good diffusion into the methanol. The pressure was raised to 100 bar and the temperature to $40{ }^{\circ} \mathrm{C}$, above the critical point of carbon dioxide. Three cycles of 45 minutes were performed, renewing the carbon dioxide between each cycle to complete the drying process 24 . After this, silica aerogels were correctly obtained, keeping the adherence to the walls of the microchannels.

\subsection{Proof-of-concept setup}

Once $\mathrm{Cu} / \mathrm{ZnO}$ based plasmonic composites were integrated into the glass microchannels, a test of these devices was made. In order to test the reactor concept, a reaction system has been built that included visual LED illumination and control of temperature the reaction while a precise control of flow and pressure is provided. A scheme of the experimental plant is presented in Figure 1.3.

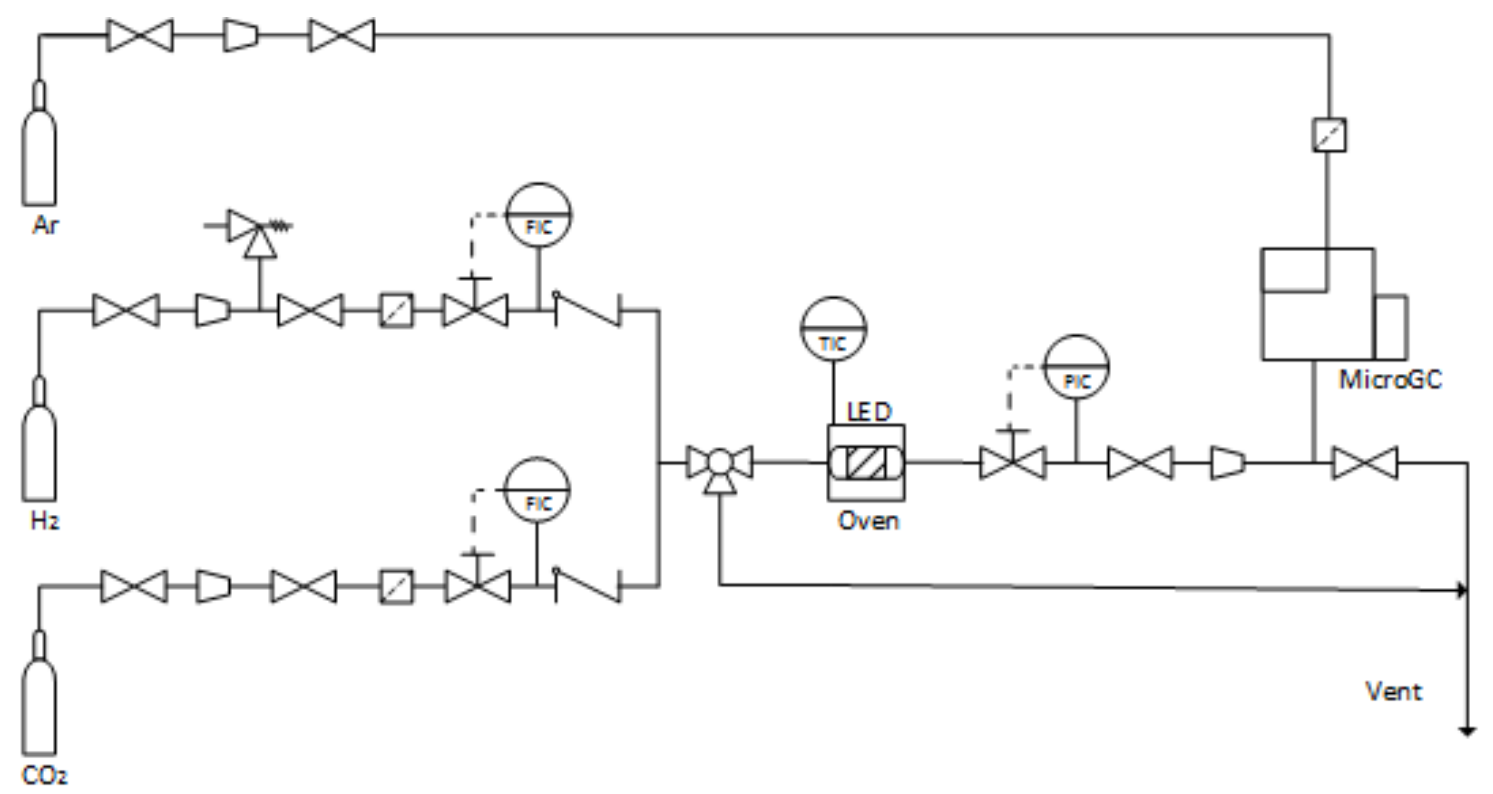

Figure 1.3. Schematic flow diagram of the plant. 
Hydrogen and carbon dioxide were introduced in the system, and their flows were controlled with two different flow mass meter/controllers (EL-Flow F-200, Bronkhorst) with ranges from 0.02 to $1 \mathrm{ml} / \mathrm{min}$.

Before the reaction was initiated, hydrogen and carbon dioxide were mixed in a 3:1 proportion, and sent to the vent while both flows were stabilized.

When the flows were correctly controlled, the mixture of the gases went to the second part of the setup. In this part the gases were heated, together with the glass microreactor, in a gas chromatography oven (Agilent 7890). The microreactor consisted on a $0.5 \mathrm{~mm}$ ID glass capillary with an external diameter of $5 \mathrm{~mm}$ (Schott Duran, USA).

A second vent was used to take out the gases while the pressure was increasing to 20 bar. Pressure was controlled by a pressure meter/controller (EL-Press series, Bronkhorst). When pressure and flows were stable at 20 bar, the valve for extraction was closed, and the oven and LEDs were turned on.

Visual light stimulation was provided by 36 LEDs (Superbright, inspired LED) surrounding the microreactor, as shown in Figure 1.4. In total, they provided the equivalent to a nominal power of $9780 \mathrm{~W} / \mathrm{m}^{2}$ of white light.
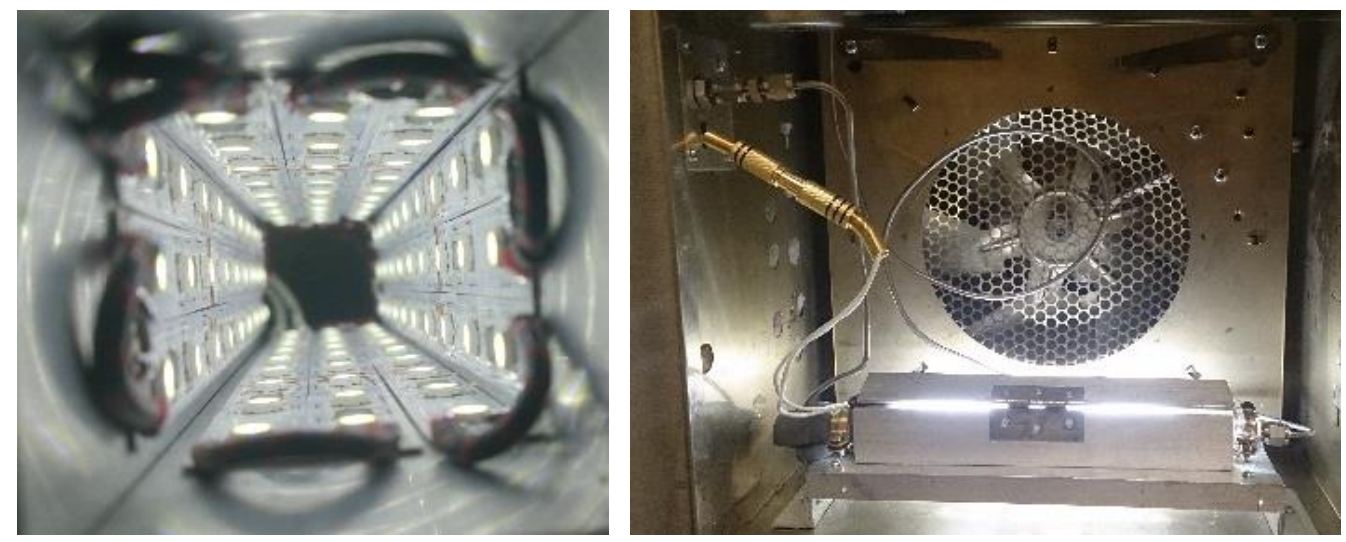

Figure 1.4. LED light configuration: detail of the inner LED distribution (Left); microreactor in the oven surrounded by the LEDs (Right). 
The reaction began and the products of the reaction were measured in a Micro Gas Chromatograph (CP-4900, Varian) equipped with two columns: a poraplot 10m and a $5 \mathrm{~A}$ molsieve. Before the micro GC, the pressure of the gas stream was reduced to less than 5 bar.

\subsection{Composites characterization}

Scans of the bimetallic catalysts to check absorbance of visual light were carried out in a UV-Vis spectrometer (UV 2550, Shimadzu). XRD analysis were carried out in a Bruker Discover D8 diffractometer. The porosity measurements were carried out in a Surface Area and Porosity Analyser (ASAP 2020, Micromeritics).

\section{Results and discussion}

\subsection{Composites Characterization}

After the synthesis UV-Vis scans were made in order to check the absorption of visual light from both the $\mathrm{ZnO}$ nanorods and the bimetallic $\mathrm{Cu} / \mathrm{ZnO}$ catalyst (Figure 1.5 ).
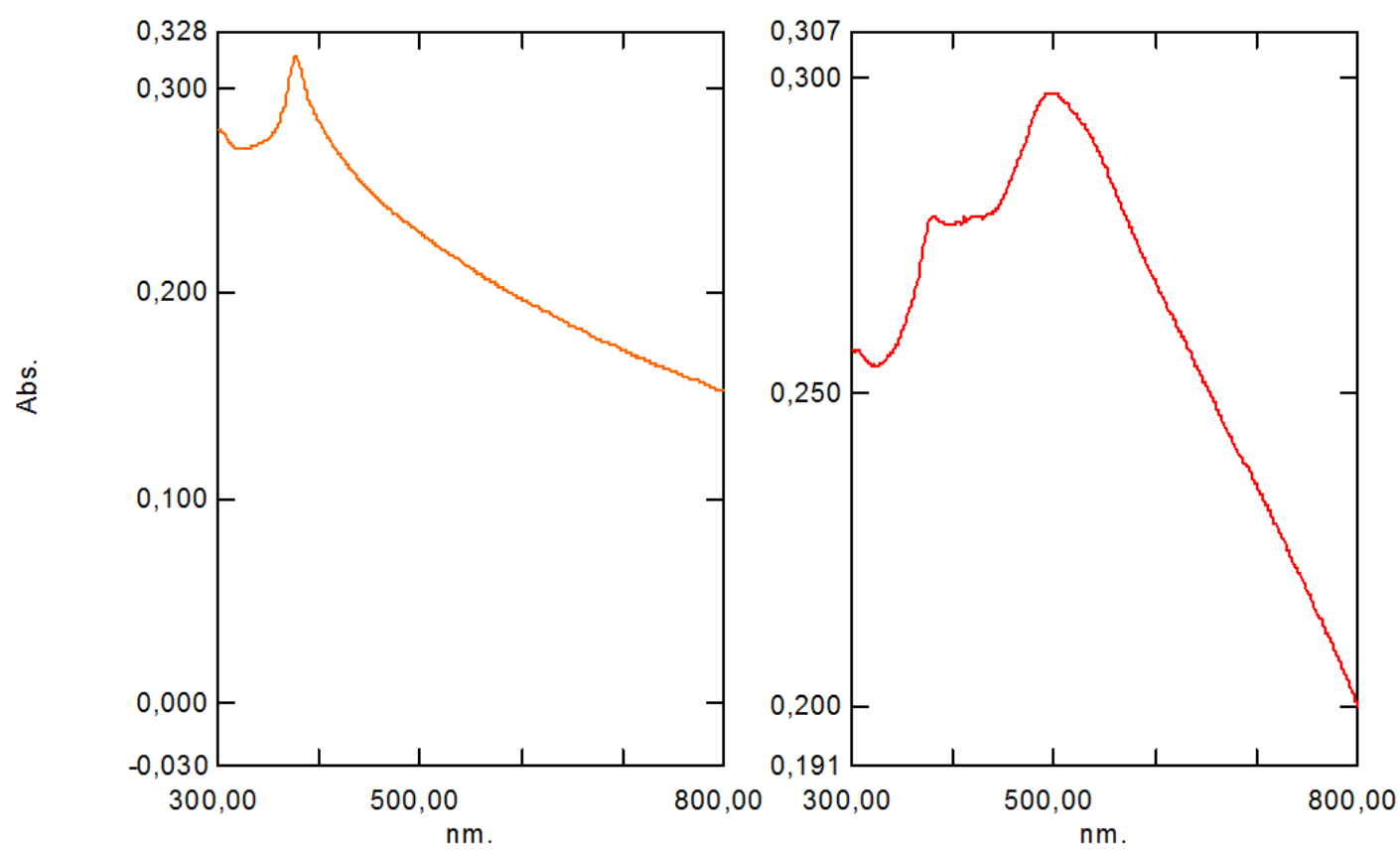

Figure 1.5. Absorption spectra of $\mathrm{ZnO}$ (left) and $\mathrm{Cu} / \mathrm{ZnO}$ (right). 
It can be seen that the bimetallic catalyst have a peak at $498 \mathrm{~nm}$. This correspond to the absorption of the range close to the green colour ${ }^{25}$. The transparent aerogels change and acquire colour once the composite is formed (Figure 6). It can be seen that the bimetallic catalyst have a peak at $498 \mathrm{~nm}$. This correspond to the absorption of the range close to the green colour $^{25}$. The transparent aerogels changed and acquired colour once the composite was formed (Figure 1.6).
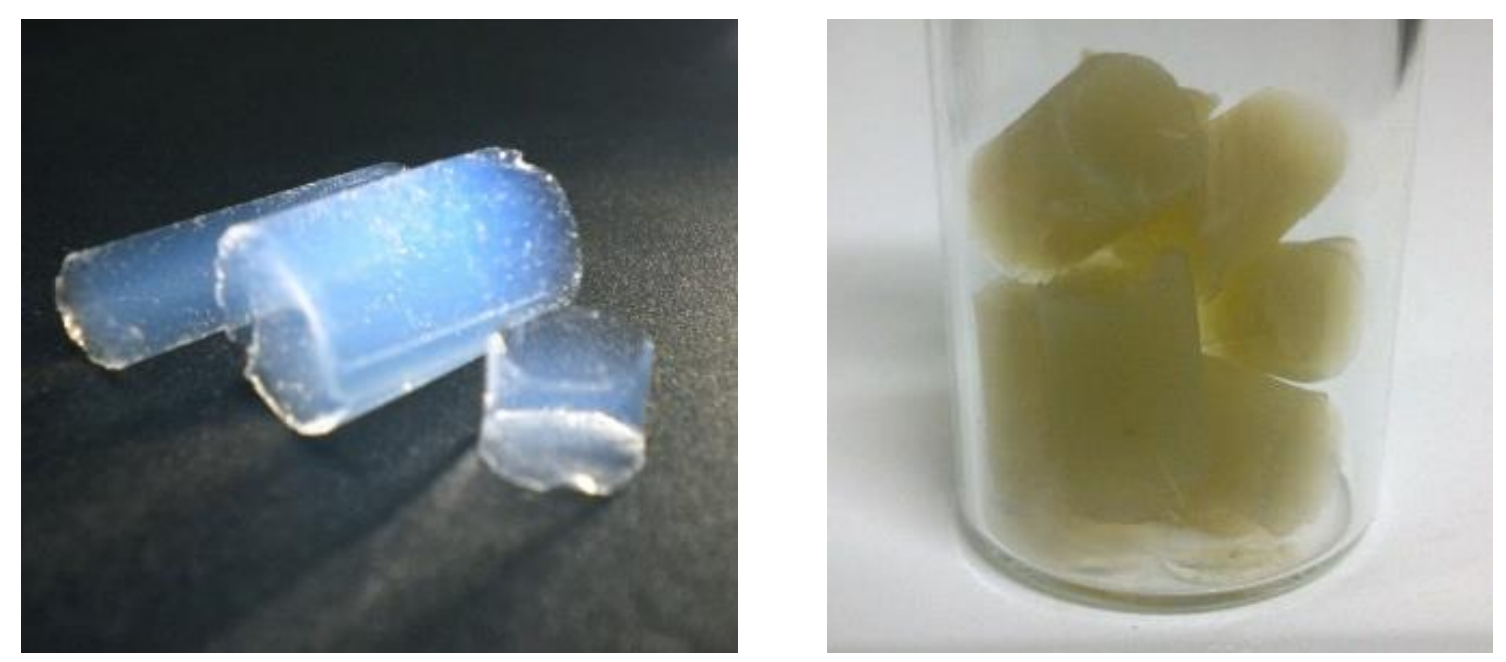

Figure 1.6. Silica aerogel before (left) and after (right) catalyst impregnation.

The XRD shows the presence of the $\mathrm{ZnO}$ and metallic copper in the silica amorphous structure. The $\mathrm{ZnO}$ planes $100(2 \theta=31,7 \mathrm{o}), 002(2 \theta=34.4 \mathrm{o}), 101$ $(2 \theta=36,10)$ and $110(2 \theta=56,40)$ can be identified in Figure 1.7. Copper cannot be seen owing to its lower proportion in the structure. 


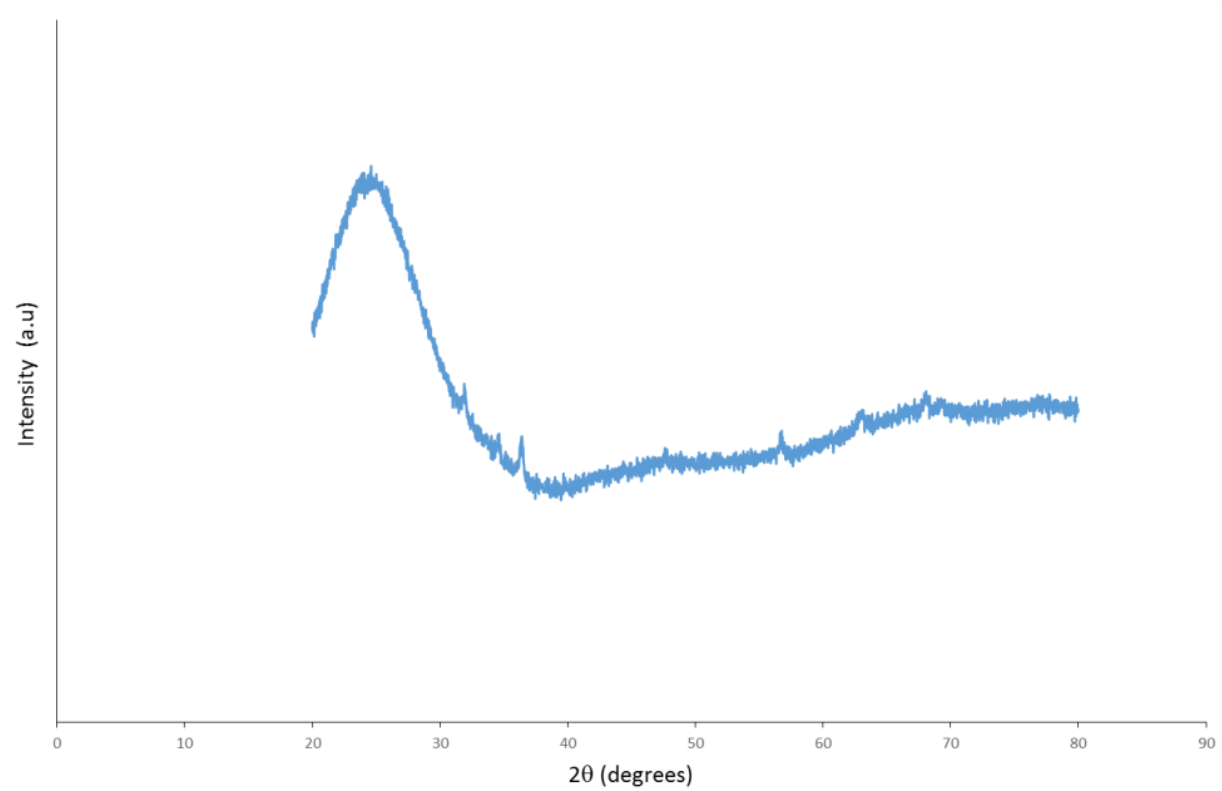

Figure 1.7. XRD pattern of the plasmonic composite.

BET surface area and pore volume of the samples were calculated from $\mathrm{N}_{2}$ isotherm. The adsorption-desorption curve show a type IV isotherm curve typical for mesoporous silica aerogels $^{26}$ (Figure 1.8). The BET surface area is $945.8 \mathrm{~m}^{2} / \mathrm{g}$ which indicates that the inclusion of the bimetallic catalyst does not have a significant influence on the textural properties of the aerogel. The BJH pore volume is equal to $2.29 \mathrm{~cm} 3 / \mathrm{g}$ reinforcing that the structure is not affected.

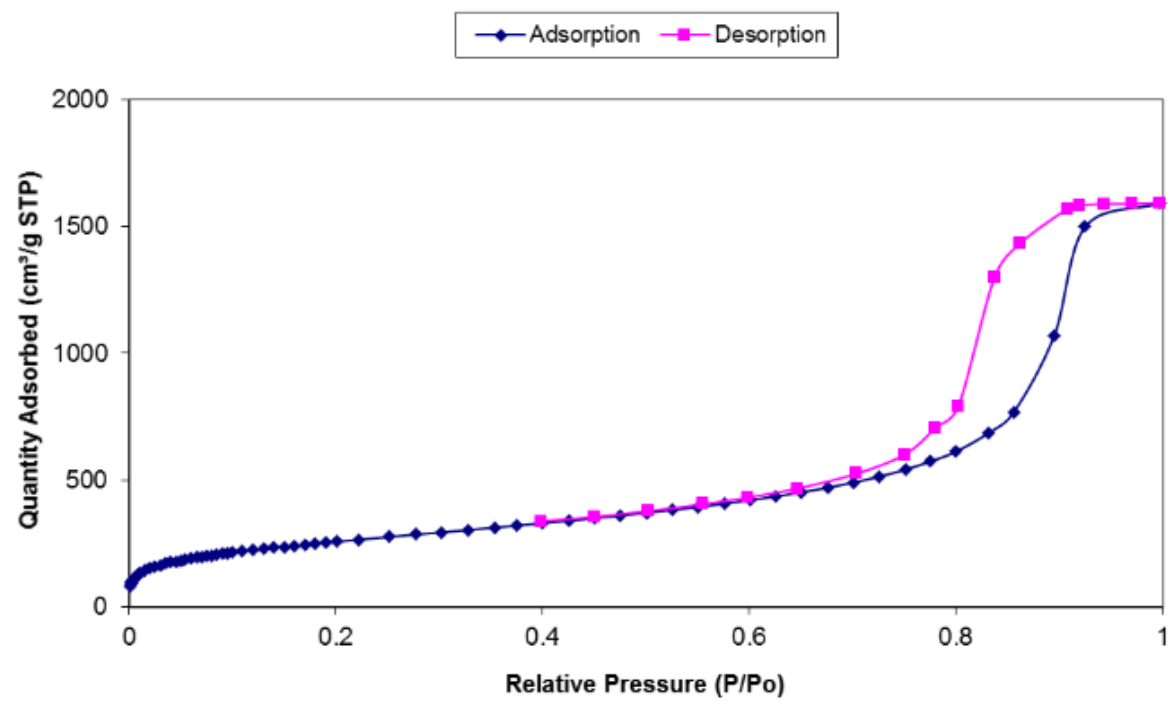

Figure 1.8. Adsorption-desorption isotherms of the composites. 


\subsection{Reaction test of the concept}

The full power of the LED was applied and the evolution of the compounds were followed. In order to test the influence of the main variables of the process, changes in flow and temperature were made during the reaction (Figure 1.9).

It could be observed that the reaction was stable at $50{ }^{\circ} \mathrm{C}$ during more than 100 minutes. Then the temperature was increased at $70{ }^{\circ} \mathrm{C}$ and tested during the same time span. Finally, the flow was reduced to half of the initial condition. No significant changes were observed during almost 300 minutes. Which indicates the suitability of this system to test several catalyst loads and thermodynamic conditions.

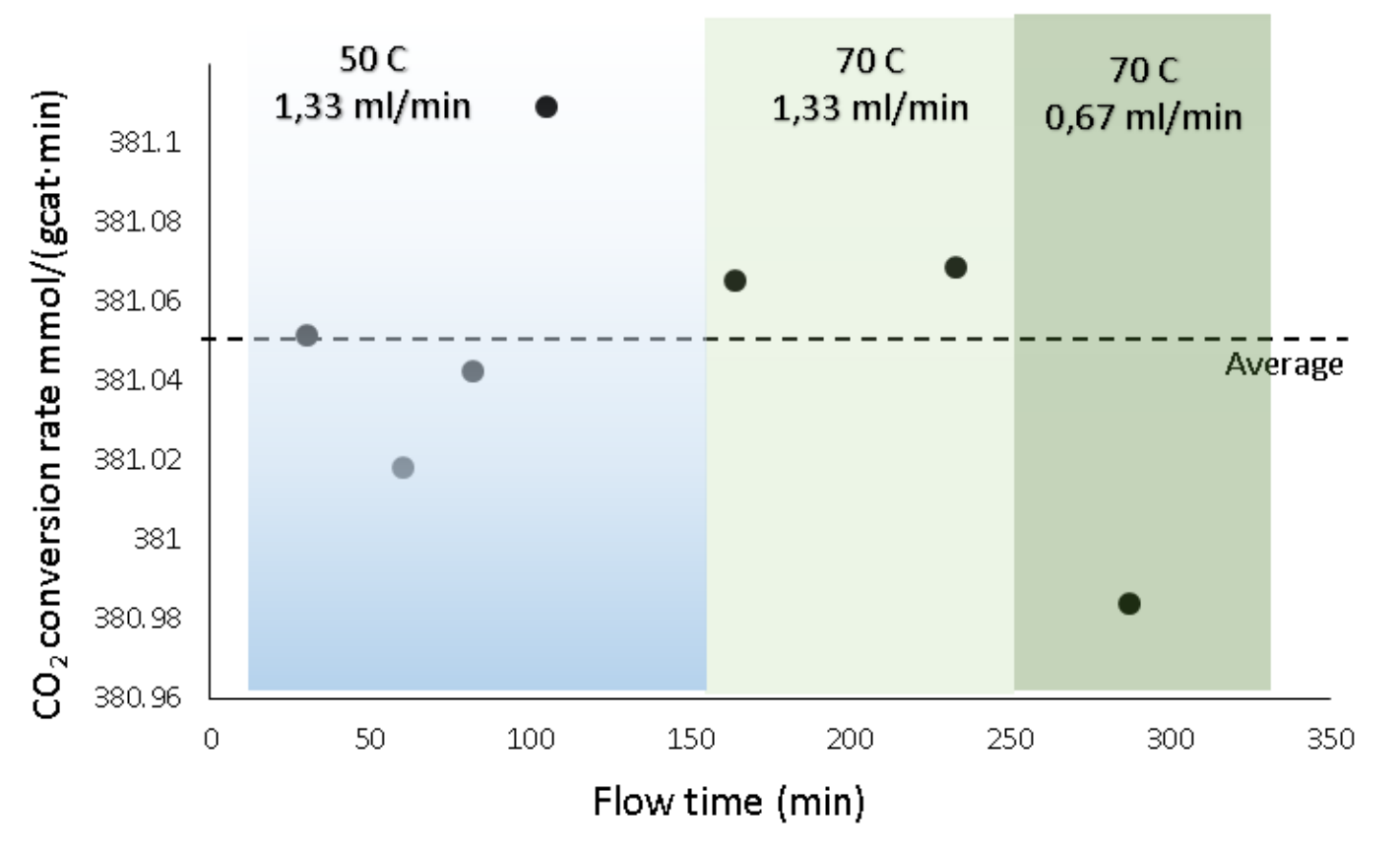

Figure 1.9. Evolution of the reaction.

It is important to note that the average conversion rate is similar to the one obtained in other works at temperatures around $200{ }^{\circ} \mathrm{C}^{17}$. Thus, the integrated plasmonic reactor concept proposed here opens new avenues to couple low temperature solar collectors and 
chemistry as a mean to introduce renewable energy in the economy. Particularly, for the conversion of $\mathrm{CO}_{2}$.

\section{Conclusions}

A novel plasmonic composite was developed that can absorb light from the visible spectrum. Its characterization evidenced a high surface area and a proper integration with the metallic components of the catalyst.

It was then possible to introduce this composite into glass microchannels in order to obtain a single entity that acts as both a light-harvesting device and as a reactor. This is possible owing to the development of a simple yet effective impregnation method that allows the synthesis of the aerogels "in situ".

The microreactor obtained was tested for RWGS in a system that allowed not only to control the reaction variables such pressure, temperature and flow. But also, delivers visual light in an elegant way.

The $\mathrm{CO}_{2}$ conversion rates were in accordance to other works testing plasmonic catalysts at higher temperatures. This can be owed to the increased light energy delivery, the high surface area of the material and to the integrated and efficient way to deliver the radiant energy possible in this reactor. This is then a novel opportunity to gain understanding on the field of $\mathrm{CO}_{2}$ use applying solar energy. 


\section{References}

1. Centi, G., Quadrelli, E. A., Perathoner, S., Catalysis for $\mathrm{CO}_{2}$ conversion: A key technology for rapid introduction of renewable energy in the value chain of chemical industries. Energy \& Environmental Science, 2013, 6, 1711-1731.

2. Centi, G., Perathoner, S., Green Carbon Dioxide: Advances in $\mathrm{CO}_{2}$ Utilization (book), eds. G. Centi and S. Perathoner, 2014, vol. John Wiley \& Sons.

3. Ogura, K., Yano, H., Tanaka, T., Selective formation of ethylene from $\mathrm{CO}_{2}$ by catalytic electrolysis at a three-phase interface. Catalysis Today, 2004, 98, 515-521.

4. Angamuthu R., et al., Electrocatalytic $\mathrm{CO}_{2}$ conversion to oxalate by a copper complex. Science, 2010, 327, 313-315.

5. Li, H., et al., Integrated electromicrobial conversion of $\mathrm{CO}_{2}$ to higher alcohols. Science, 2012, 335, 1596.

6. Rosen, B. A., et al., Ionic liquid-mediated selective conversion of $\mathrm{CO}_{2}$ to $\mathrm{CO}$ at low overpotentials. Science, 2011, 334, 643-644.

7. Barton, E. E., Rampulla, D. M., Bocarsly, A. B., Selective solar-driven reduction of $\mathrm{CO}_{2}$ to methanol using a catalyzed p-GaP based photoelectrochemical cell. Journal of the American Chemical Society, 2008, 130, 6342-6344.

8. Smestad, G. P., Steinfeld, A., Review: Photochemical and thermochemical production of solar fuels from $\mathrm{H}_{2} \mathrm{O}$ and $\mathrm{CO}_{2}$ using metal oxide catalysts. Industrial \& Engineering Chemistry Research, 2012, 51, 11828-11840.

9. Ermanoski, I., Miller, J.E., Allendorf, M.D., Efficiency maximization in solarThermochemical fuel production: Challenging the concept of isothermal water splitting. Physical Chemistry Chemical Physics, 2014, 16, 8418-8427.

10. Forster, M., Investigations to convert $\mathrm{CO}_{2}, \mathrm{NaCl}$ and $\mathrm{H}_{2} \mathrm{O}$ into $\mathrm{Na}_{2} \mathrm{CO}_{3}$ and $\mathrm{HCl}$ by thermal solar energy with high solar efficiency. Journal of CO2 Utilization, 2014, 7, 1118.

11. Dhakshinamoorthy, A., et al., Photocatalytic $\mathrm{CO}_{2}$ reduction by $\mathrm{TiO}_{2}$ and related titanium containing solids. Energy \& Environmental Science, 2012, 5, 9217-9233. 
12. Tran, P. D., et al., Recent advances in hybrid photocatalysts for solar fuel production. Energy \& Environmental Science, 2012, 5, 5902-5918.

13. Neațu, Ș., Maciá-Agulló, J., Garcia, H., Solar light photocatalytic $\mathrm{CO}_{2}$ reduction: General considerations and selected bench-mark photocatalysts. International Journal of Molecular Sciences, 2014, 15, 5246.

14. Linic, S., Christopher, P., and Ingram, D.B., Plasmonic-metal nanostructures for efficient conversion of solar to chemical energy. Nature Materials, 2011, 10, 911-921.

15. Hägglund, C., Apell, S. P., Kasemo, B., Maximized optical absorption in ultrathin films and its application to plasmon-based two-dimensional photovoltaics. Nano Letters, 2010, 10, 3135-3141.

16. Garcia, M. A., Surface plasmons in metallic nanoparticles: Fundamentals and applications. Journal of Physics D: Applied Physics, 2011, 44, 283001.

17. Upadhye, A. A., et al., Plasmon-enhanced reverse water gas shift reaction over oxide supported Au catalysts. Catalysis Science \& Technology, 2015, 5, 2590-2601.

18. Wang, C., et al., Visible light plasmonic heating of $\mathrm{Au}-\mathrm{ZnO}$ for the catalytic reduction of $\mathrm{CO}_{2}$. Nanoscale, 2013, 5, 6968-6974.

19. Behrens, M., et al., The active site of methanol synthesis over $\mathrm{Cu} / \mathrm{ZnO} / \mathrm{Al}_{2} \mathrm{O}_{3}$ industrial catalysts. Science, 2012, 336, 893-897.

20. Tan, Z. Y., et al., Nanostructured $\mathrm{Cu} / \mathrm{ZnO}$ coupled composites: Toward tunable $\mathrm{Cu}$ nanoparticle sizes and plasmon absorption. The Journal of Physical Chemistry C, 2013, 117, 10780-10787.

21. Gascon, J., et al., Structuring catalyst and reactor - An inviting avenue to process intensification. Catalysis Science \& Technology, 2015, 5, 807-817.

22. Louis, B., et al., Rational Design of Microporous and Mesoporous Solids for Catalysis: From the Molecule to the Reactor. ChemCatChem, 2011, 3, 1263-1272.

23. Pajonk, G. M., Transparent silica aerogels. Journal of Non-Crystalline Solids, 1998, 225, 307-314. 
24. Sanz-Moral, L. M., et al., View cell investigation of silica aerogels during supercritical drying: Analysis of size variation and mass transfer mechanisms. The Journal of Supercritical Fluids, 2014, 92, 24-30.

25. NASA, What Wavelength Goes With a Color?, http://science-edu.larc.nasa.gov/EDDOCS/Wavelengths_for_Colors.html.

26. Al-Oweini, R., El-Rassy, H., Surface characterization by nitrogen adsorption of silica aerogels synthesized from various $\mathrm{Si}(\mathrm{OR})_{4}$ and $\mathrm{R}^{\prime \prime} \mathrm{Si}\left(\mathrm{OR}^{\prime}\right)_{3}$ precursors. Applied Surface Science, 2010, 257, 276-281. 



\section{CHAPTER 2}

\section{Study of the influence of the reaction variables}





\section{Introduction}

Carbon dioxide conversion into useful products is attracting much attention in the last years as a way to reduce greenhouse effect and its dramatic consequences for the planet ${ }^{1,2}$. Among the options to perform this $\mathrm{CO}_{2}$ conversion, photocatalytic processes using solar energy are presented as an interesting way to transform $\mathrm{CO}_{2}$ due to the use of a renewable energy. $\mathrm{CO}_{2}$ can be transformed into methanol which is a chemical commodity and can store the energy from the $\operatorname{sun}^{3,4}$. Transforming $\mathrm{CO}_{2}$ into methanol using solar energy generates therefore two benefits at the same time: the reduction of $\mathrm{CO}_{2}$ emissions and the storage of energy from renewable sources.

Photocatalytic $\mathrm{CO}_{2}$ transformation usually shows low conversions because the efficiency of the process is limited ${ }^{5}$. One of the reasons is that most of the catalysts just absorb a little amount of the light energy in the visible or ultraviolet band. Surface Plasmon Resonance (SPR) is a phenomenon found in some metallic nanostructures that results in a higher light energy absorbance that can be controlled with the shape and size of the nanoparticles. Commonly, gold and silver nanoparticles have been studied to enhance SPR effect ${ }^{6,7}$, although other metals such as copper also produce this effect ${ }^{8}$. Similarly, copper has been widely used for carbon dioxide hydrogenation in industry combined with the use of zinc oxide in order to produce methanol with high selectivity ${ }^{9}$. For this reason, a combination of both materials $\mathrm{Cu} / \mathrm{ZnO}$ could be also used to perform carbon dioxide hydrogenation by means of solar energy using SPR as a way to enhance the efficiency of the process and to maximize the $\mathrm{CO}_{2}$ transformation.

SPR effect depends on copper nanoparticles size, whose variation can modify the wavelength where visual light is absorbed ${ }^{10}$. Carbon dioxide hydrogenation is performed in the contact area between zinc oxide and copper nanoparticles ${ }^{11}$, giving a crucial 
importance to maximize this contact area with the synthesis method chosen. For this reason, it is needed to synthesize discrete copper nanoparticles whose final size can be controlled and to deposit them onto zinc oxide nanoparticles avoiding agglomeration.

Carbon dioxide and hydrogen can produce methanol directly in a one-step reaction. However, the conversion is increased when the transformation is carried out in two steps ${ }^{12}$. First, carbon dioxide is transformed in carbon monoxide (endothermic) and after this CO again with hydrogen produce methanol (exothermic).

In this work, glass microreactors are selected to perform the carbon dioxide hydrogenation because they provide great homogeneity in the light distribution through the reactor ${ }^{13}$. Glass microreactors avoid light absorption interferences, allowing to study the influence of the material properties and reaction conditions in $\mathrm{CO}_{2}$ conversion.

In order to fix the catalyst inside the microreactors a support is required. This support must provide high surface areas to load the bimetallic catalyst, ensuring that light is not absorbed by the support and can reach the catalyst to activate it. Silica aerogels are micromesoporous materials with high surface areas $\left(400-1500 \mathrm{~m}^{2} / \mathrm{g}\right)$ and high visible transparency ${ }^{14}$, properties that place them as the best option to be used as a support in this work.

Therefore, a bimetallic catalyst $\mathrm{ZnO} / \mathrm{Cu}$ supported in silica aerogels can be activated with light and be used to perform carbon dioxide hydrogenation in glass microreactors. In a previous work, the viability of the idea was tested with good results ${ }^{15}$, opening the possibility to improve the process optimizing the reaction parameters. With the purpose of increasing $\mathrm{CO}_{2}$ conversion rate, a complete study of the influence of some reaction 
variables such as temperature, pressure, catalyst amount and reactants proportion is going to be performed.

\section{Experimental methods}

\subsection{Reagents}

The chemicals used during this stage were: Zinc acetate dihydrate ( $>98 \%)$, oleylamine $(70 \%)$, tetramethyl orthosilicate (98\%), ammonia (30\%), triethylenglicol $(99 \%)$ were purchased from Sigma-Aldrich. Ethylenglicol (99.5\%) (Merck). Copper acetate monohydrate (99.9\%) was purchased from Alfa Aesar. Methanol (99.8\%) was purchased from Panreac.

\subsection{Synthesis of plasmonic catalyst}

Following the method proposed by Tan et al $(2013)^{16}$, zinc oxide nanorods can be developed firstly and then copper nanoparticles are deposited onto in a second step controlling the final size of the nanoparticles and the wavelength where visual light is absorbed.

Oleylamine / Zinc acetate ratio is the most important parameter that defines the final shape of zinc oxide nanoparticles. In order to produce nanorods, $3 \mathrm{mmol}$ of zinc acetate were mixed with $1.3 \mathrm{ml}$ of oleylamine in a three necked flask. After degassing the mixture at $80^{\circ} \mathrm{C}$ for $45 \mathrm{~min}$ in vacuum atmosphere, a nitrogen stream was introduced to the system and the temperature was increased to $220{ }^{\circ} \mathrm{C}$ for $15 \mathrm{~min}$. After this, the final product obtained was a white paste stuck to the bottom of the flask. $10 \mathrm{ml}$ of ethanol were used with stirring to remove the solid product, and then it was centrifuged (centrifuge Kubota 5100, Japan) at $5000 \mathrm{rpm}$ in order to isolate the precipitate. It was washed again twice 
with $5 \mathrm{ml}$ of ethanol to ensure a perfect removal of the reactants. $\mathrm{ZnO}$ nanorods prepared were redispersed in $20 \mathrm{ml}$ of triethylenglicol for two hours by sonication, and then stirred under room conditions overnight.

After that, a dual glycol system was prepared to deposit copper oxide nanoparticles onto the $\mathrm{ZnO}$ nanorods. $1.5 \mathrm{mmol}$ of copper acetate was added in a second pot to $4 \mathrm{ml}$ of ethylenglicol, using sonication for $1 \mathrm{~h}$ to create a homogeneous solution. $2 \mathrm{ml}$ of ethylenglicol were also added to the zinc oxide vessel, and the solution was transferred to a three necked flask again to be degassed at ambient temperature for $10 \mathrm{~min}$. Then, the copper acetate solution was placed in an addition funnel connected to the three necks flask with the copper oxide, which was heated at $190^{\circ} \mathrm{C}$ under nitrogen purging. To avoid agglomeration, copper acetate solution was added slowly drop by drop during $10 \mathrm{~min}$. After this, the solution was cooled for being then washed and centrifuged three times with isopropanol at $5000 \mathrm{rpm}$.

\subsection{Synthesis and impregnation of silica aerogels}

The silica gels were synthetized following the method used by Sanz-Moral et al. (2014) ${ }^{17}$. The precursors used were tetramethyl orthosilicate (TMOS), methanol, water and ammonia in a $1: 2.3: 3.84: 0.012$ molar ratio. The amount of ammonia has been shown as the controlling parameter for the gelation time. Depending on the catalyst load, which also affects the gelation time, molar ratio TMOS: ammonia was varied from $1: 0.012$ to $1: 0.12$ in order to achieve the right gelation time.

Silica aerogels also represent a benefit for subsequent impregnation in the microreactors. Aerogels were produced through the sol-gel route, mixing all the precursors in a liquid state under stirring to generate the hydrogel. Among these precursors it is found methanol 
that was used before to suspend the catalyst nanoparticles by sonication. After that, methanol was mixed with the other precursors generating the silica net with $\mathrm{Cu} / \mathrm{ZnO}$ catalyst inside. This silica structure was in a liquid form for a few seconds, which allowed the impregnation in glass microreactors by using just a syringe. Then, the gelation process took place directly inside the microreactors obtaining a hydrogel well attached to the walls of the microchannels and avoiding problems of introducing a solid catalyst in a narrow microchannel. Gelation time turns into the key factor for the catalyst impregnation inside the microreactors. Gelation must be slow enough to allow injection with the syringe, although if it is too slow precipitation of the catalyst will start and the final structure will not be homogeneous.

First, methanol with the catalyst nanoparticles was mixed with TMOS in a small glass and stirred for a few minutes. At the same time, a second glass with water and ammonia was also stirred and covered to avoid ammonia evaporation. Then, both solutions were mixed and the syringe was used to fill the microreactor. After a few seconds, the liquid turned into the hydrogel with the catalyst inside showing good adhesion and homogeneity along the entire length of the glass microreactor $(15 \mathrm{~cm})$.

\subsection{Aerogels supercritical drying}

Before carrying out the drying with supercritical $\mathrm{CO}_{2}$, an intermediate step was required for aging the hydrogels ${ }^{18}$. In this stage, the microreactors were placed in a vessel filled with methanol and closed for one week. The aim was to exchange the water in the aerogel for methanol producing alcogels that were dried later with supercritical $\mathrm{CO}_{2}$. In order to ensure no water remained in the structure, methanol was renewed twice during the week. 
After that, the alcogels were ready to be dried with supercritical $\mathrm{CO}_{2}$. The experimental plant for aerogels drying (Figure 2.1) had an oven to heat the system at $45{ }^{\circ} \mathrm{C}$, and $\mathrm{CO}_{2}$ was pumped at 110 bar above the supercritical point ${ }^{17}$. Inside the oven there was a high pressure vessel that was filled with methanol before microreactors were placed inside.

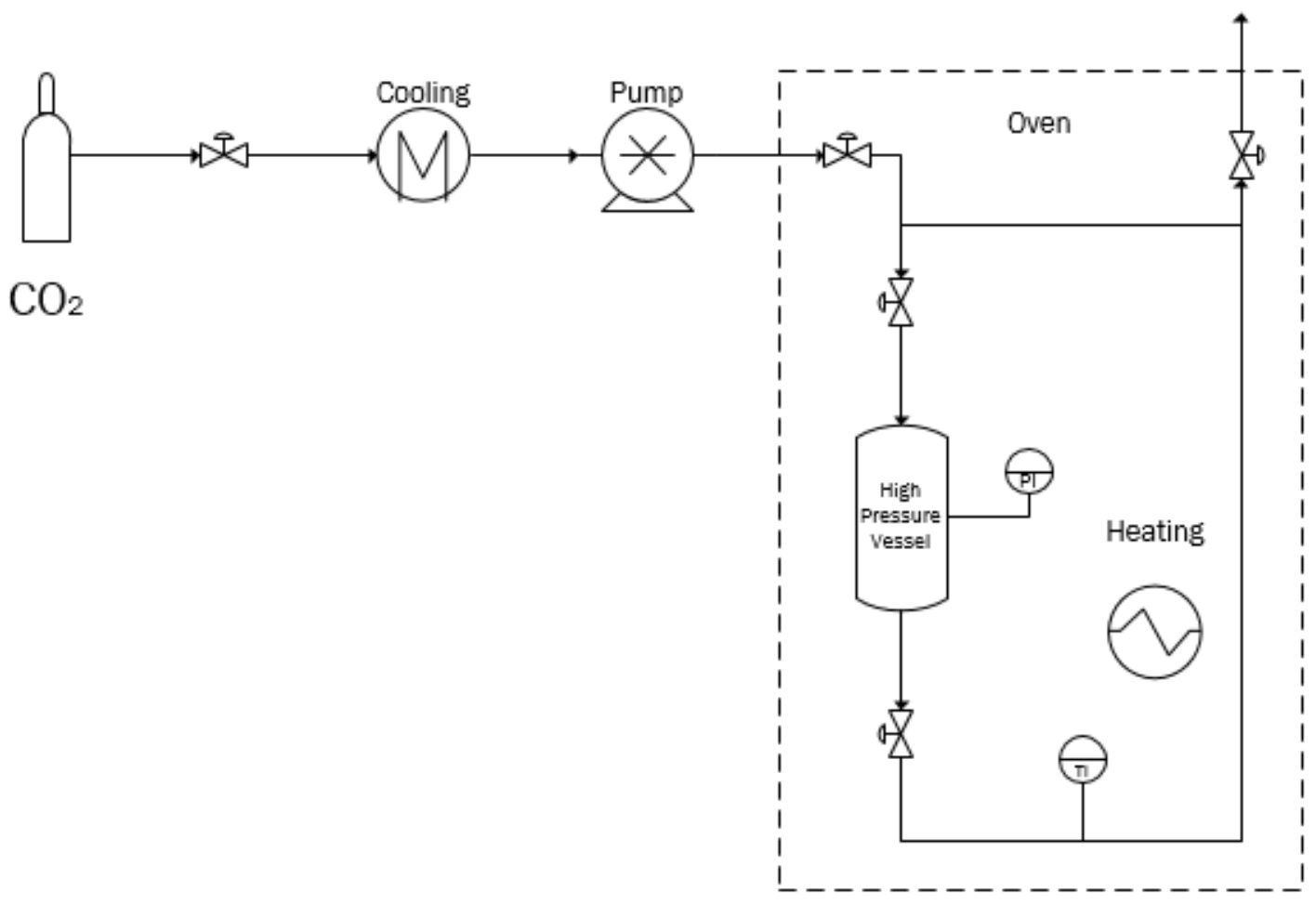

Figure 2.1. Silica aerogels drying plant.

When the high pressure vessel was closed, the upper valve was slightly opened to introduce the supercritical carbon dioxide and to increase slowly the pressure (if there is a sudden change of pressure in the vessel the aerogels could be broken). After pressure in the vessel reached 110 bar, the lower valve was also opened in order that carbon dioxide started to circulate through the complete system for $45 \mathrm{~min}$. As the system operates in batch and methanol is thus accumulated in the $\mathrm{CO}_{2}$ phase, four drying cycles were performed, renewing $\mathrm{CO}_{2}$ between each cycle to ensure a complete drying of methanol. 
The final products were the aerogels correctly formed and with great adherence to the microchannel walls.

\subsection{Experimental reaction plant}

After microreactors were prepared to perform the reaction, they were carried to the experimental setup where carbon dioxide hydrogenation was performed. This plant (Figure 2.2) was used in previous work to test the reactor concept with good results ${ }^{15}$.

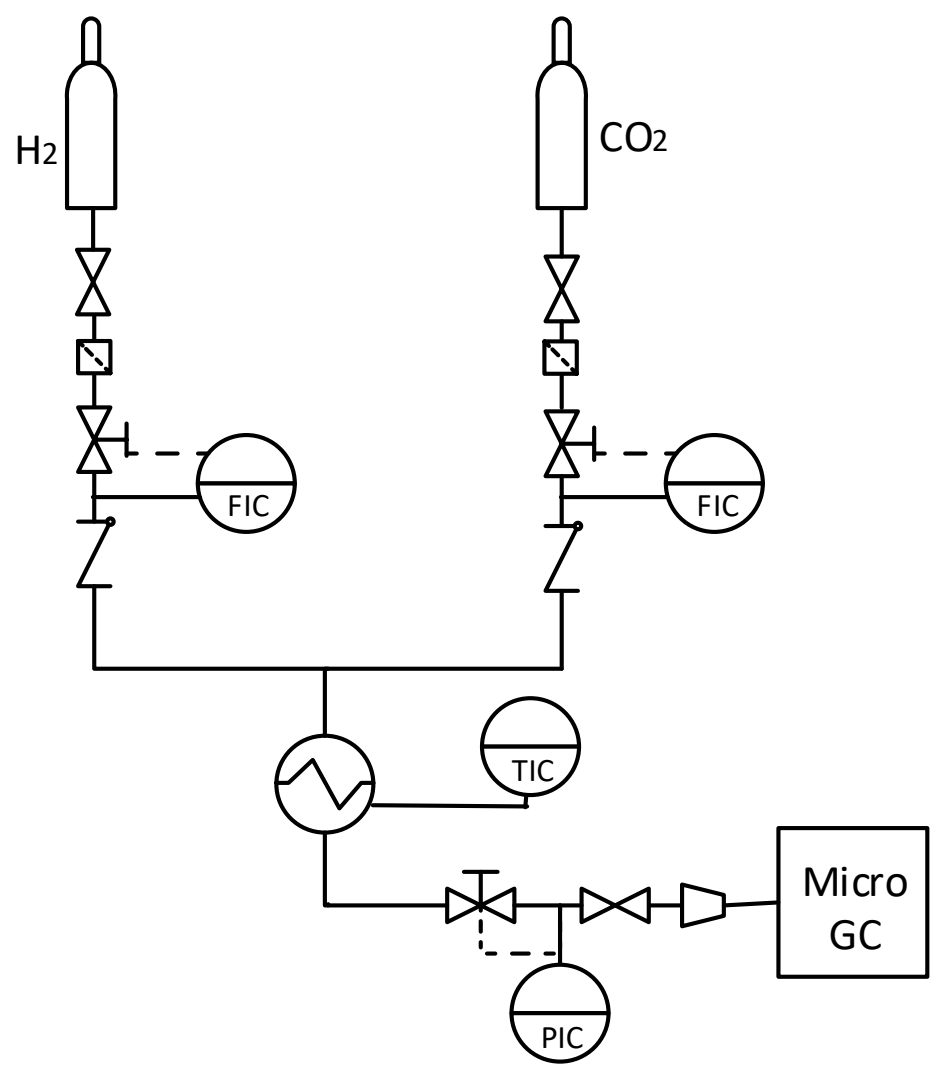

Figure 2.2. Carbon dioxide hydrogenation experimental plant.

The experimental setup has been designed to be able to control the reaction parameters that can have influence in the carbon dioxide transformation, such as pressure, temperature and gas inlet flows. The plant had two flow mass meter/controllers (EL-Flow F-200, Bronkhorst) for $\mathrm{H}_{2}$ and $\mathrm{CO}_{2}$ with ranges up to $1 \mathrm{ml} / \mathrm{min}$. Temperature was controlled by placing the microreactors inside a gas chromatography oven (Agilent 7890) 
and pressure was controlled by a pressure meter/controller (EL-Press series, Bronkhorst) located at the exit of the oven.

The microreactor consisted on a $0.5 \mathrm{~mm}$ ID glass capillary with an external diameter of $5 \mathrm{~mm}$ (Schott Duran, USA). The microreactor was surrounded by a set of LEDs (Superbright, inspired LED) that provided white light in the most homogeneous way to illuminate correctly the entire reactor. The gas outlet stream was measured with a Micro Gas Chromatograph (CP-4900, Varian) equipped with two columns: a poraplot $10 \mathrm{~m}$ and a $5 \mathrm{~A}$ molsieve.

\subsection{Catalyst characterization}

Light absorbance tests for the $\mathrm{ZnO} / \mathrm{Cu}$ catalyst were performed using a $\mathrm{UV}$-Vis Spectrophotometer (Shimadzu UV 2550). Transmission Electron Microscopy was carried out with a JEOL JEM-2100F UHR for catalyst nanoparticles, and with a JEOL JEMFS2200 HRP for silica nanocomposites. The chemical structure of the aerogel was studied by Fourier Transform Infrared Spectroscopy (FTIR model TENSOR from Bruker). Accelerated Surface Area and Porosimetry Systems (ASAP 2020 and 2420 from Micromeritics) were used to calculate the specific surface area and to determine the nitrogen isothermal adsorption - desorption curve.

\section{Results and discussion}

\subsection{Catalyst characterization}

Transmission Electron Microscopy was used to check the correct formation of $\mathrm{ZnO}$ nanorods, and to prove that copper nanoparticles were deposited onto nanorods surface (Figure 2.3) before loading the catalyst in the aerogel. 

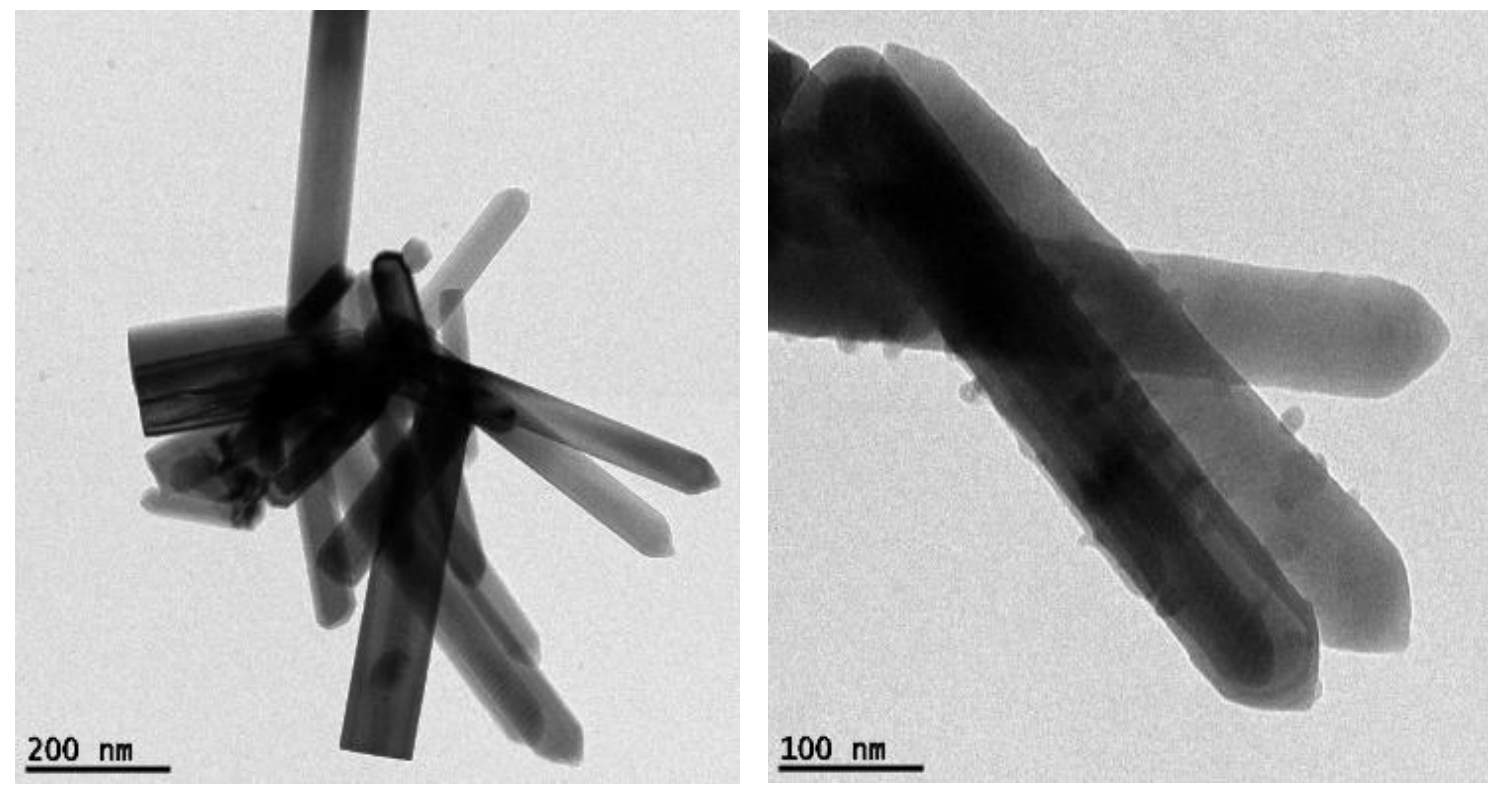

Figure 2.3. TEM images of $\mathrm{ZnO}$ nanorods (left) and copper nanoparticles deposited onto $\mathrm{ZnO}$ nanorods (right).

It can be seen that $\mathrm{ZnO}$ nanorods are correctly created and discrete copper nanoparticles are formed on the $\mathrm{ZnO}$ surface without agglomeration as it was expected. Moreover, the impregnation of the catalyst inside the silica net was also studied in order to ensure catalyst was properly loaded (Figure 2.4).

By using dark field technique selecting the reflections of each element it is shown the distribution of silica, zinc and copper in the structure. Silica is the main component and appears throughout the structure, while zinc oxide nanoparticles are found all together inside the silica structure. For copper nanoparticles, it can be seen that most of them are located in the zinc oxide area, what means that they are correctly deposited onto $\mathrm{ZnO}$ nanorods. However, an important amount of copper nanoparticles are found far away from zinc oxide nanorods due to they were not correctly deposited, not reaching the full efficiency of the process. 

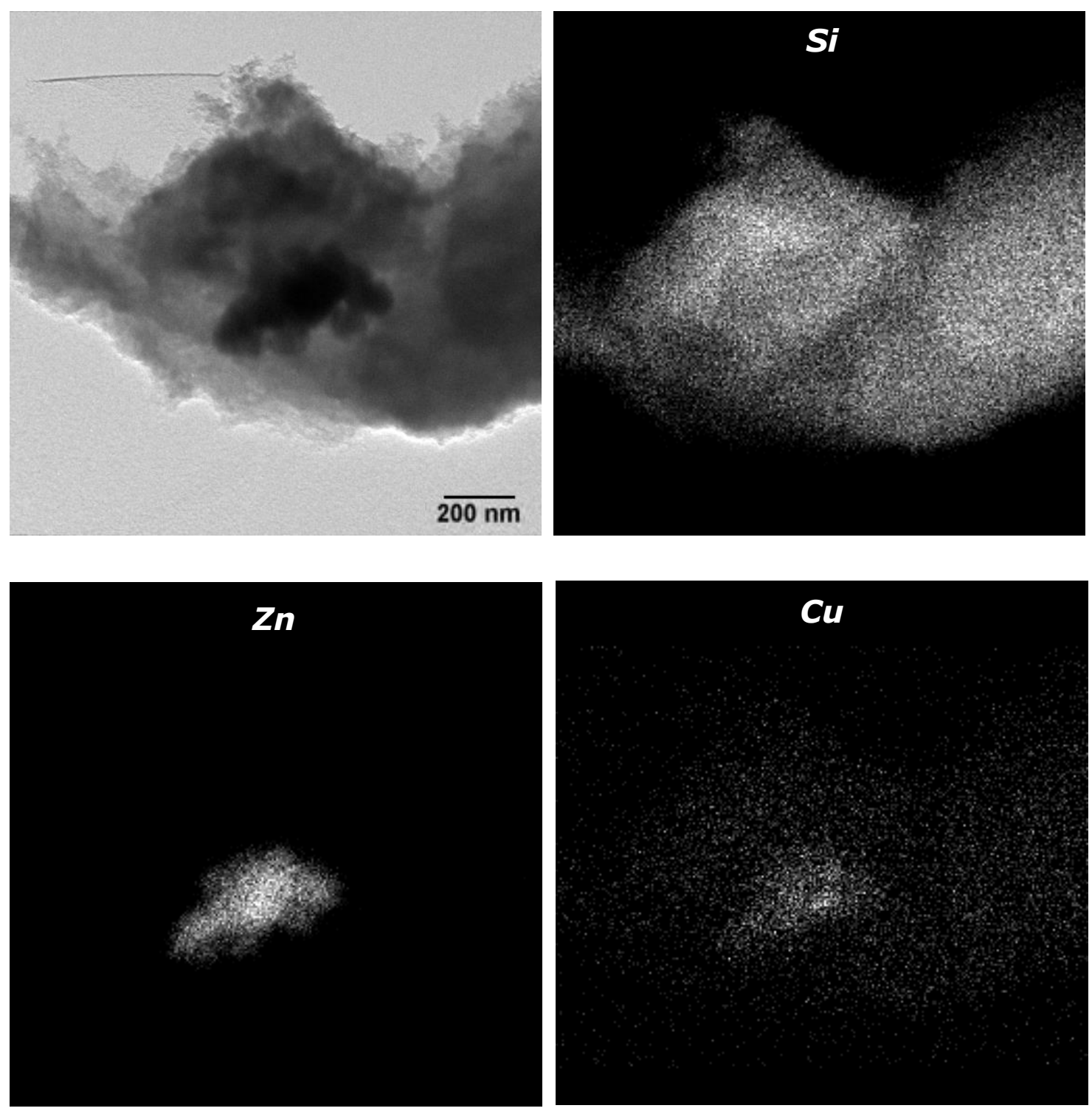

Figure 2.4. TEM image of a silica aerogel with catalyst and dark field to identify silica, zinc and copper distribution.

Light absorption of this bimetallic catalyst was tested by UV-Vis Spectrophotometry (Figure 2.5) in order to prove both materials were absorbing light in visible band (copper) and ultraviolet band (zinc oxide). 


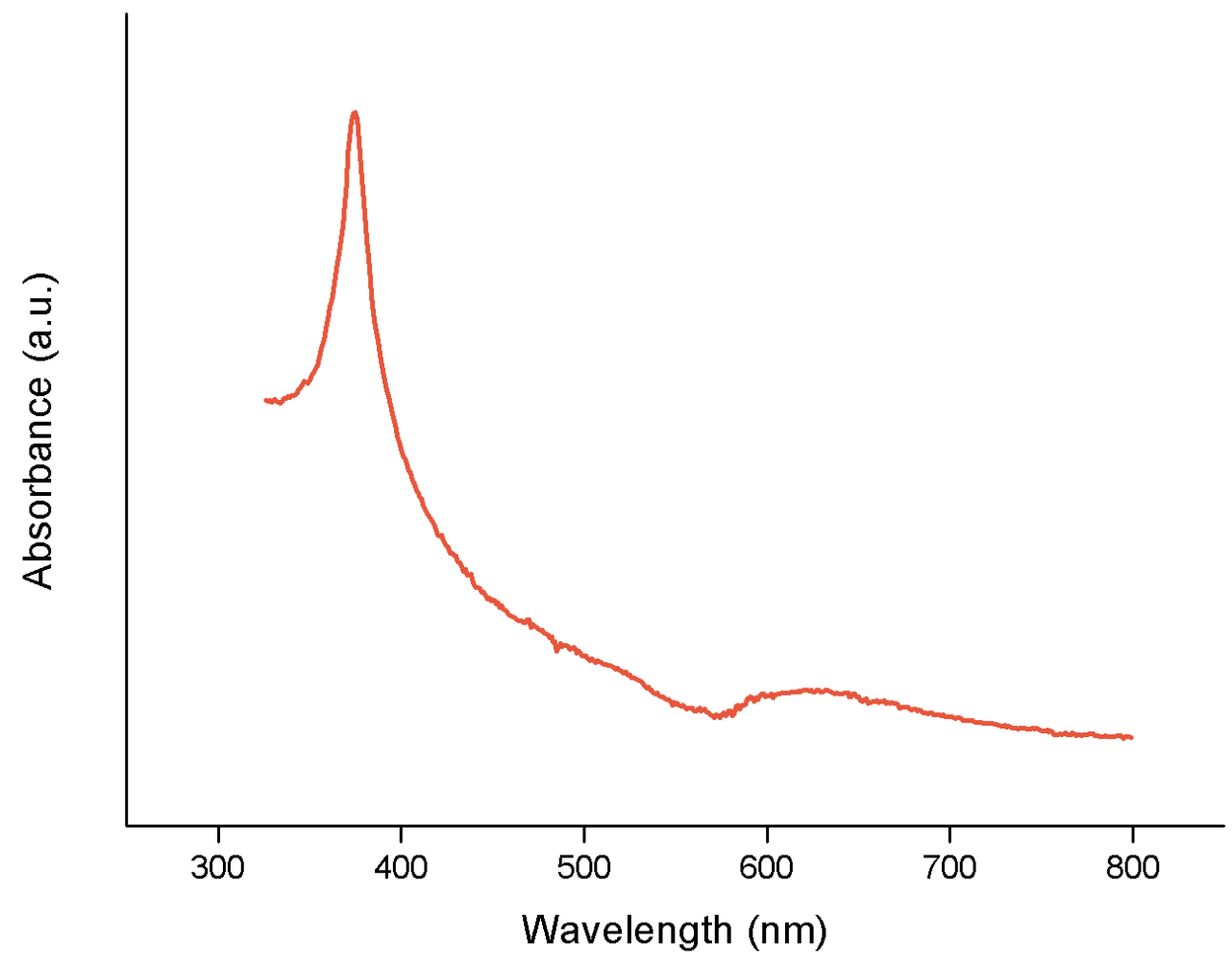

Figure 2.5. UV-Vis absorption spectra of $\mathrm{ZnO} / \mathrm{Cu}$ catalyst.

$\mathrm{ZnO}$ nanorods exhibit a peak at $370 \mathrm{~nm}$, and $\mathrm{Cu}$ nanoparticles induce a peak around 600 $\mathrm{nm}$, which corresponds to the absorption of the range between orange and red colour ${ }^{19}$. The not-perfect definition of a peak can be related with a not constant size of nanoparticles, moving in a narrow range of sizes but not enough to define a clear peak.

FTIR analysis was used to study the influence of catalyst loading in the structure of the aerogel. With this purpose, silica aerogel without catalyst was first analysed, in order to obtain the IR spectra of the silica material and identify all its chemical bonds. After that, two different amount of catalyst loads ( 7 and $10 \%$ in weight) were analysed to study if their addition affected the silica structure or the nanoparticles were located inside the porous structure without creating new bonds (Figure 2.6). 


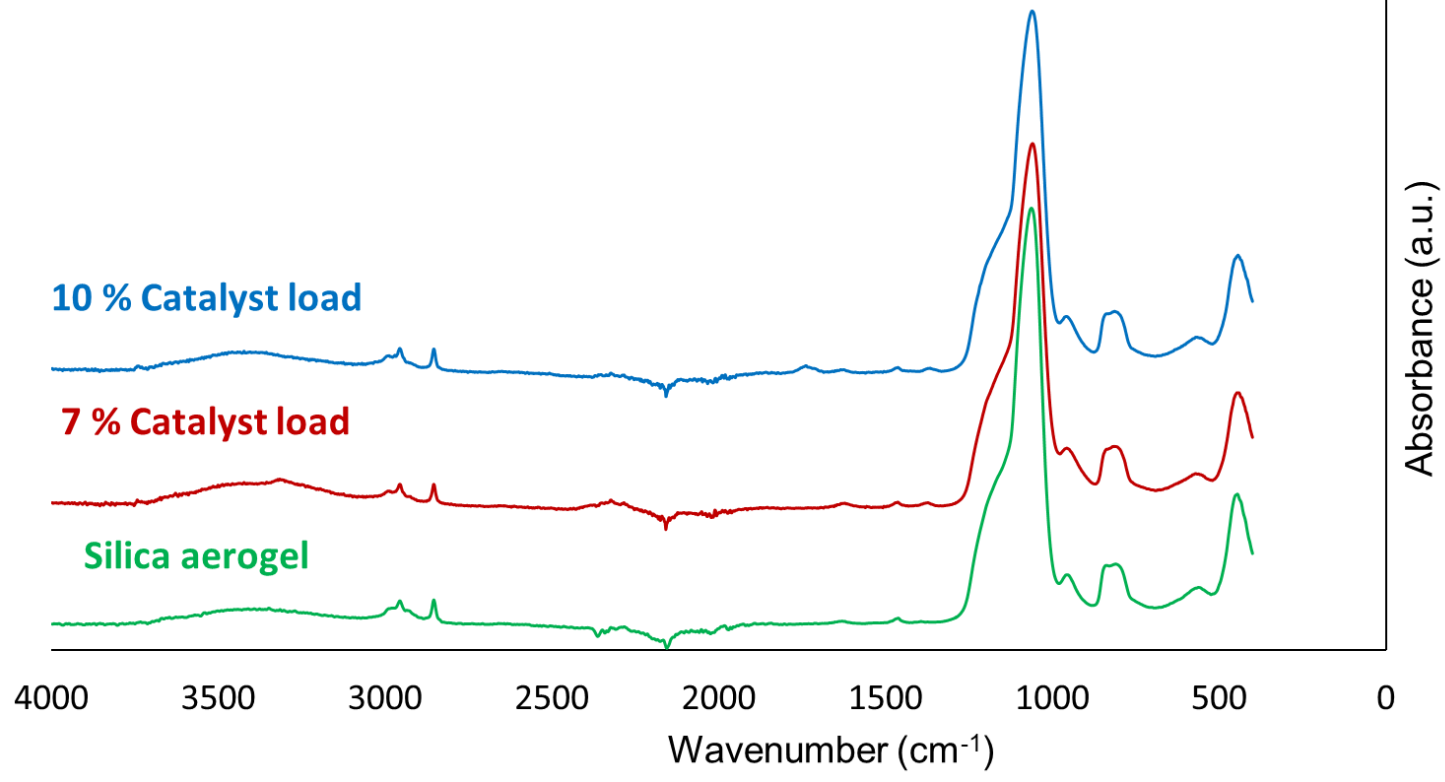

Figure 2.6. FTIR spectra of silica aerogel without and with catalyst load.

In the silica aerogel spectra the main peaks of the silica structure can be observed. The most intense and broad peak can be found at $1050 \mathrm{~cm}^{-1}$ with a shoulder at around 1200 $\mathrm{cm}^{-1}$ due to $\mathrm{Si}-\mathrm{O}-\mathrm{Si}$ asymmetric stretching vibrations ${ }^{20}$. The symmetric stretching vibrations of Si-O-Si can also be observed at $800 \mathrm{~cm}^{-1}$. When catalyst is impregnated in the aerogel, no significant peaks are added to the spectra, and the silica structure peaks are still correctly formed, concluding that catalyst loads do not affect the chemical structure of the aerogel.

Same samples were analysed to determine the surface area and pore volume depending on catalyst load. Both properties were calculated from $\mathrm{N}_{2}$ isotherm adsorption desorption curve, that showed for all the samples a type IV isotherm curve that is usual for mesoporous silica aerogels ${ }^{21}$ (Figure 2.7). Almost no differences were found when $7 \%$ and $10 \%$ catalyst were loaded in the aerogel. 


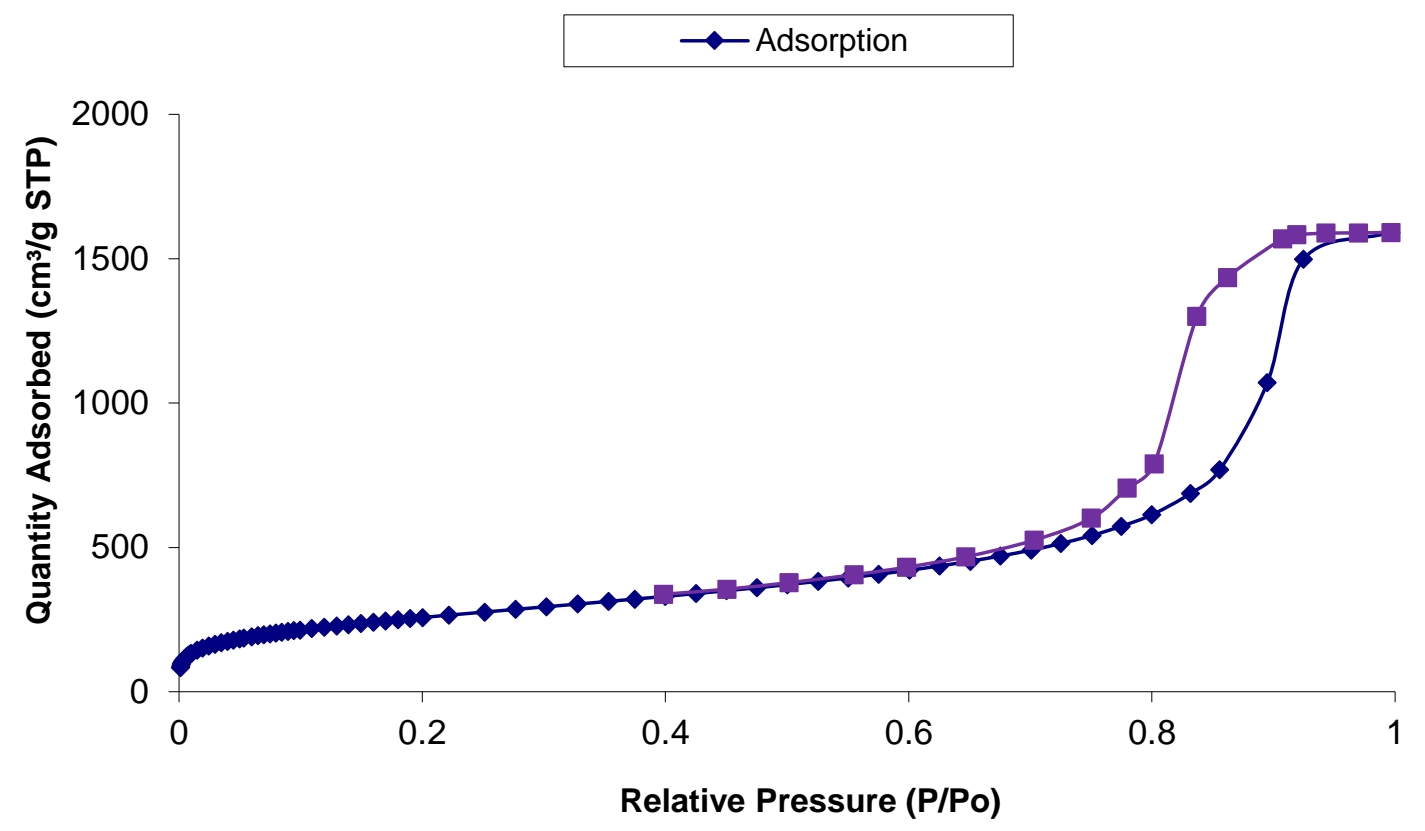

Figure 2.7. Isotherm adsorption - desorption curve for silica aerogels.

The BET surface area was $845.3 \mathrm{~m}^{2} / \mathrm{g}$ for silica aerogels, and it was slightly reduced to 843.4 and 842.7 for 7 and $10 \%$ catalyst load, respectively. This indicates that the presence of catalyst does not have influence on the textural properties of the silica aerogel. However, the impact of the inclusion of catalyst in the porous structure can be seen in the pore volume. For silica aerogels the BJH pore volume calculated was $2.91 \mathrm{~cm}^{3} / \mathrm{g}$, being reduced to 2.46 and $2.29 \mathrm{~cm}^{3} / \mathrm{g}$ for 7 and $10 \%$ catalyst load, respectively. Loading more catalyst leads to lower pore volume.

\subsection{Carbon dioxide hydrogenation}

After the proof of concept previously done working at 20 bar and 50 and $70{ }^{\circ} \mathrm{C}^{15}$, a complete study of the influence of different parameters has been done. The variables whose influence have been studied are the preheating temperature of gases, pressure, gas inlet mass flows and amount of catalyst. 


\subsubsection{Influence of temperature}

The first parameter studied was the temperature for gases preheating. Carbon dioxide hydrogenation is going to be activated my means of plasmonic catalytic activation, although gases temperature can have influence in the process.

In order to analyse this variable several experiments were performed. First of all, an initial experience working without connecting the LEDs was carried out in order to analyse if the reaction could be performed only with temperature. Working always at 20 bar, $10 \%$ catalyst loaded and flows of $1 \mathrm{ml} / \mathrm{min}$ for hydrogen and $0.33 \mathrm{ml} / \mathrm{min}$ for carbon dioxide, experiences at 50,100 and $150{ }^{\circ} \mathrm{C}$ were done and the conclusion was the same in all the cases: no conversion of carbon dioxide was produced.

After this, the same experiences were performed turning on the lights. In this case, carbon dioxide started to be transformed (Figure 2.8).

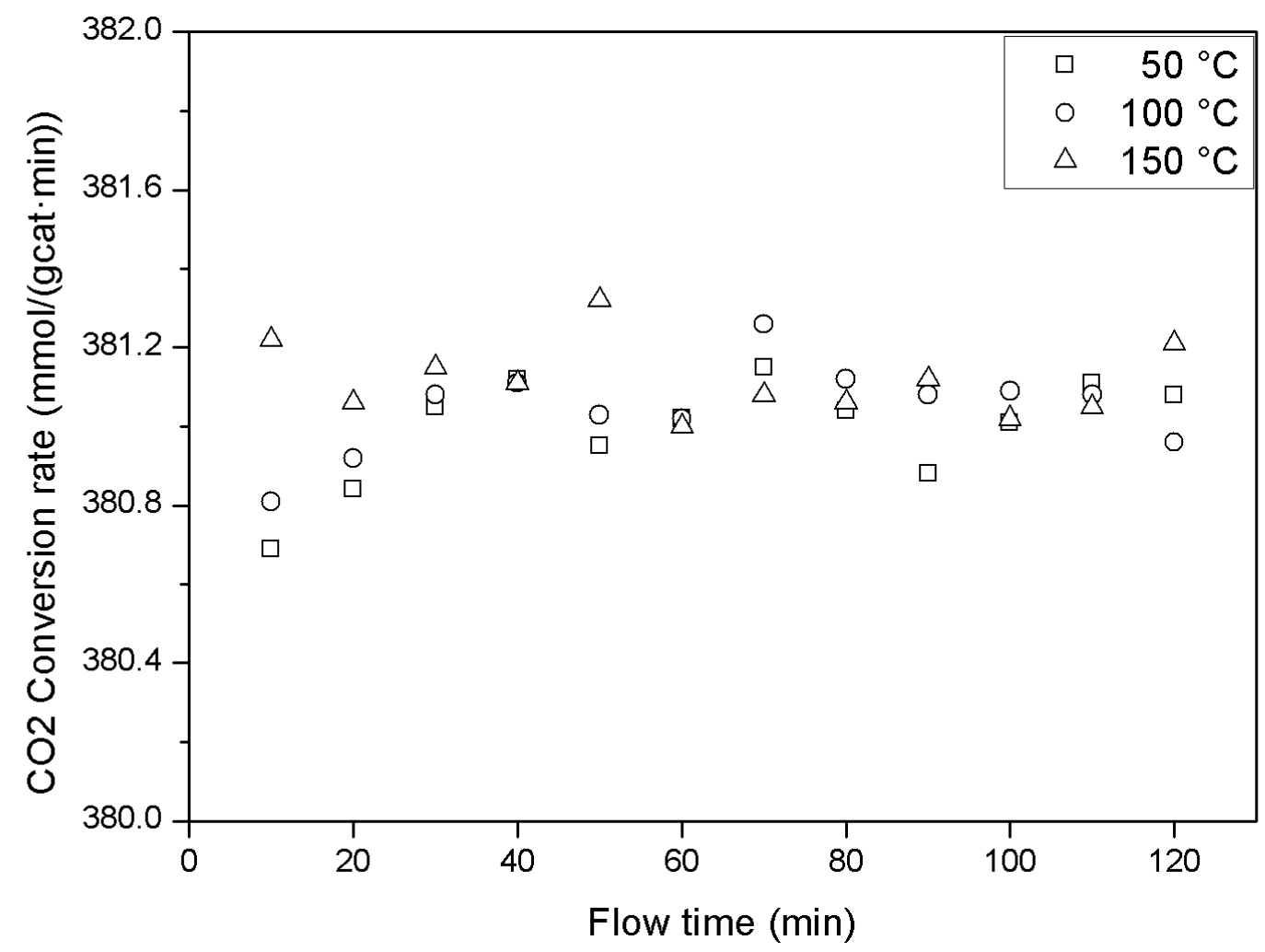

Figure 2.8. Influence of preheating temperature in the reaction. 
It can be observed that preheating of gases has almost no influence in the $\mathrm{CO}_{2}$ conversion rate and the results are constant. However, the gases flow control system does not allow to avoid preheating. Flow controllers cannot stabilize perfectly flows when the gases are cold, and they work much better with a small heating. For this reason, it was decided to work always at $50^{\circ} \mathrm{C}$ for the next experiments.

\subsubsection{Influence of catalyst amount}

Next variable to be studied was the amount of catalyst. Variation of the amount inside the aerogel was easy, because the catalyst was directly diluted in the methanol needed as a precursor for the silica aerogel. However, $13 \%$ catalyst loaded in the aerogel was the maximum amount loaded, due to gelation problems for higher loads. The gelation process must be slow enough to have time to impregnate the aerogel inside the microreactors when it is still liquid, but if this time is too long the catalyst starts to precipitate and as a result the catalyst is not well distributed throughout the silica net. Higher catalyst loads increase the gelation time, allowing catalyst precipitation when the catalyst load is above $13 \%$.

Because of this, experiments with 7,10 and $13 \%$ catalyst deposited were performed, working always at $20 \mathrm{bar}, 50{ }^{\circ} \mathrm{C}$ and flows of $1 \mathrm{ml} / \mathrm{min}$ for hydrogen and $0.33 \mathrm{ml} / \mathrm{min}$ for carbon dioxide (Figure 2.9). 


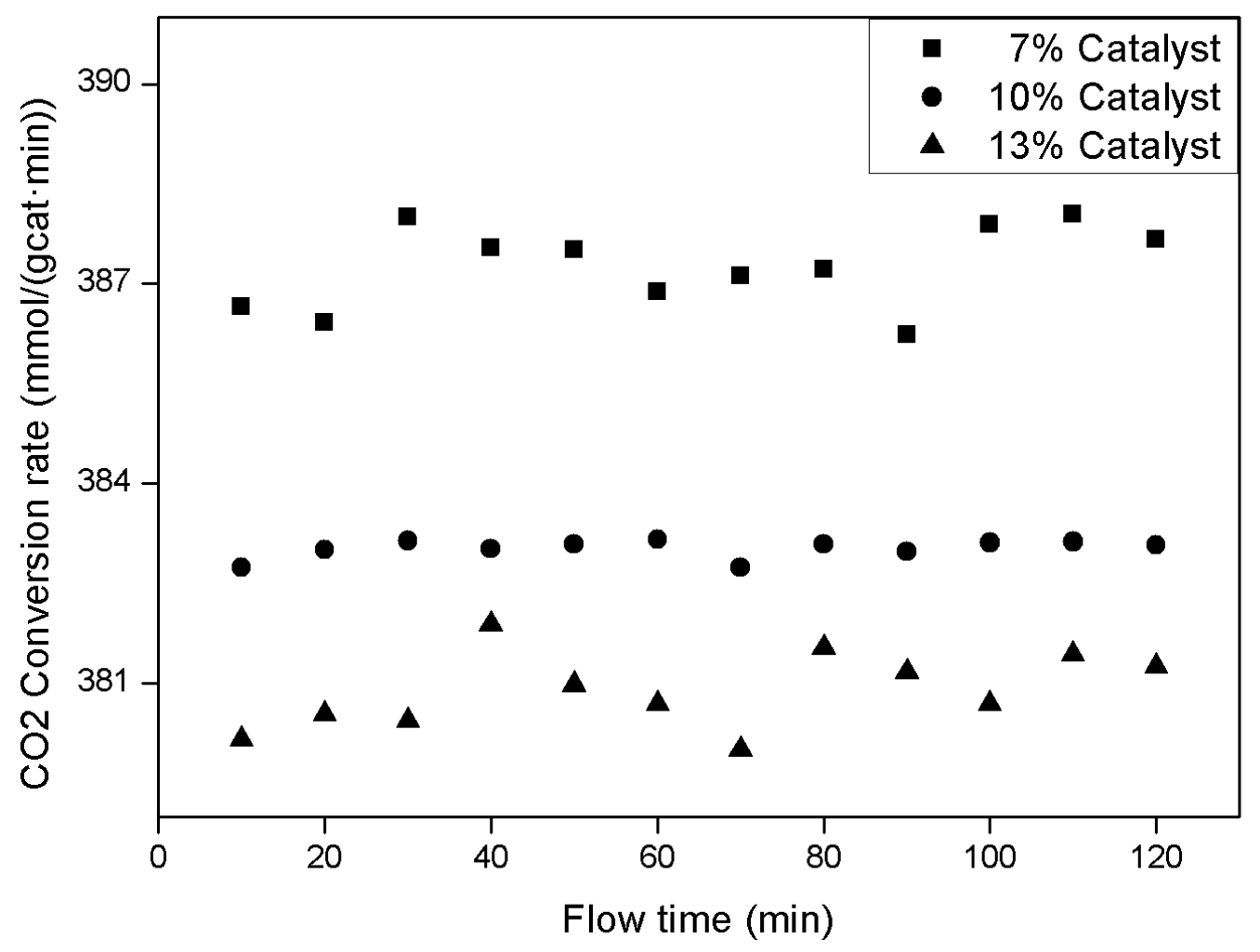

Figure 2.9. Influence of catalyst load in the reaction.

It is shown that $\mathrm{CO}_{2}$ conversion rates are higher when it decreases the amount of catalyst. Using more catalyst does not help to improve the process, attaining the opposite effect. Although metallic nanoparticles have not precipitated, they can be agglomerated inside the silica net. Agglomeration process explains the reduction in the area used for carbon dioxide hydrogenation, and this leads to a decrease in the $\mathrm{CO}_{2}$ conversion rate. In the same way, loading more catalyst reduces the light available generating a less transparent material and decreasing the volume of catalyst that is activated by light.

\subsubsection{Influence of reactants proportion}

Hydrogen and carbon dioxide flow can also have influence in the conversion rate of $\mathrm{CO}_{2}$. They have been mixed in a 3:1 proportion in order to test temperature and catalyst amount influence in the process, and it has been studied if adding more hydrogen could benefit 
the reaction (Figure 2.10). Pressure, temperature and catalyst load were $20 \mathrm{bar}, 50^{\circ} \mathrm{C}$ and $10 \%$ for all the experiences.

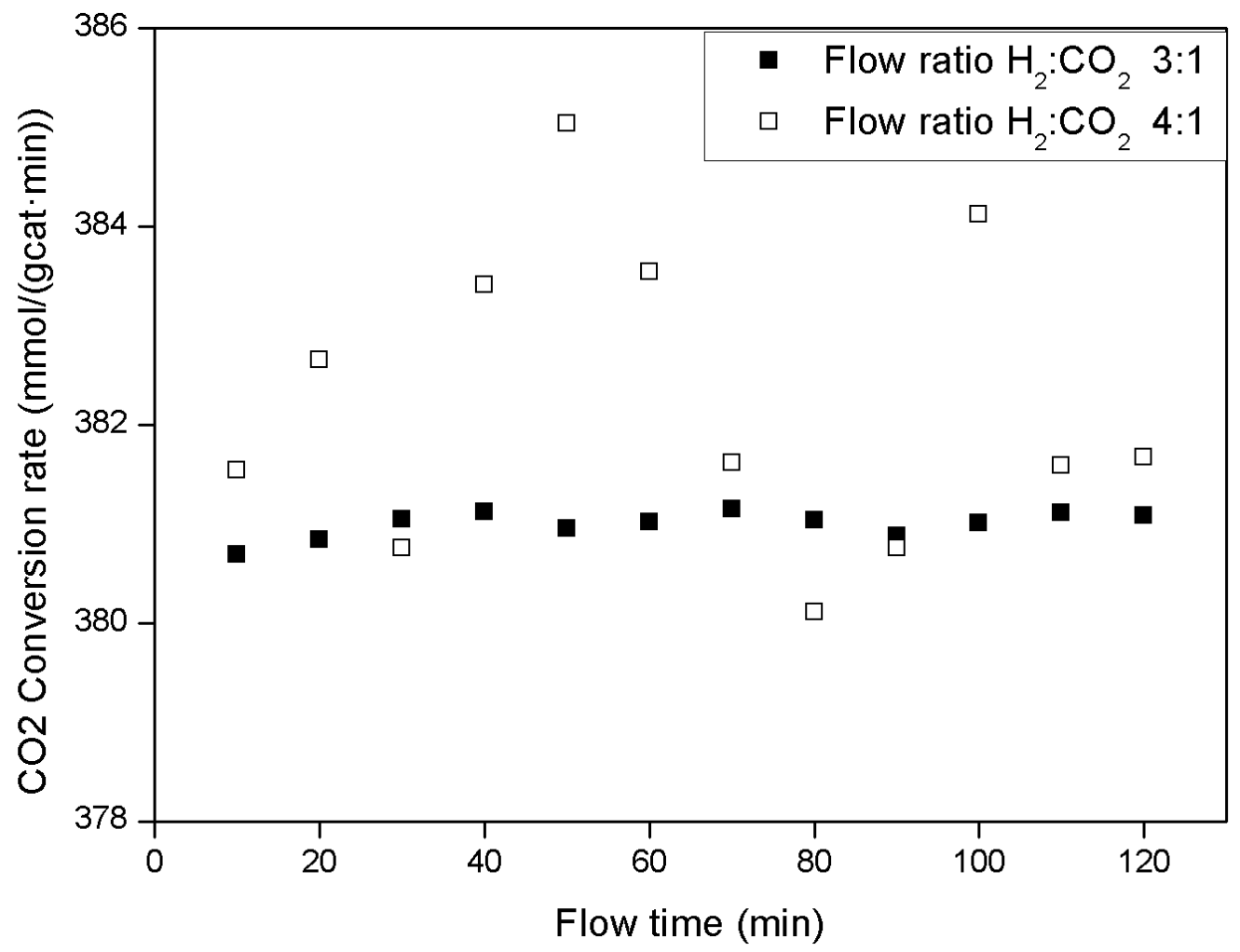

Figure 2.10. Influence of gases flow.

It can be seen that increasing hydrogen proportion is not translated into a clear improvement for the process, not making sense doing it because of the repercussion in the cost it would have for almost the same $\mathrm{CO}_{2}$ conversion rate. To achieve $4: 1$ hydrogen to carbon dioxide proportion, $\mathrm{H}_{2}$ flow remained constant at $1 \mathrm{~mol} / \mathrm{min}$, and $\mathrm{CO}_{2}$ flow was adjusted to $0.25 \mathrm{ml} / \mathrm{min}$. As the method to calculate $\mathrm{CO}_{2}$ conversion is calibration by areas, reducing the $\mathrm{CO}_{2}$ flow leads to greater sensitivity of the micro gas chromatograph, causing the results to oscillate more than in the $3: 1$ proportion. 


\subsubsection{Influence of pressure}

Finally, the last reaction variable whose influence has been studied was the pressure. Carbon dioxide hydrogenation is performed in the intersection between zinc oxide and copper nanoparticles ${ }^{11}$, where at the same time carbon dioxide molecule is attacked and hydrogen molecule is retained enough time to produce the reaction ${ }^{22}$. Increasing pressure of the system could help to this phenomenon and to improve the process because it shifts the equilibrium in order to increase the products concentration. Experiences working with 1 and $0.33 \mathrm{ml} / \mathrm{min}$ as hydrogen and carbon dioxide flows respectively, at $50{ }^{\circ} \mathrm{C}$ and $10 \%$ catalyst loaded in the aerogel, were performed. The pressure was varied between 20 and 50 bar to study its influence in the reaction (Figure 2.11).

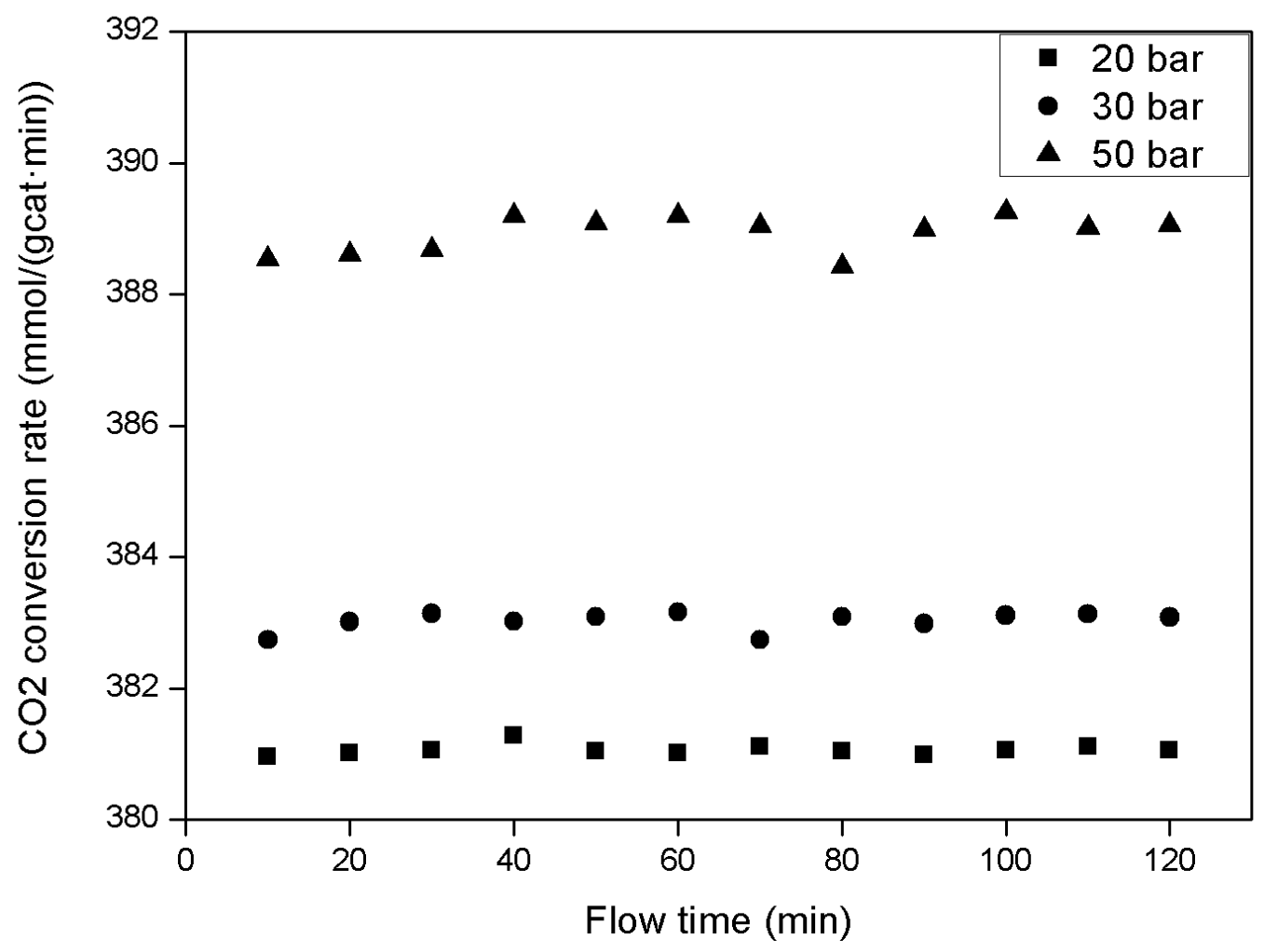

Figure 2.11. Influence of pressure in the reaction.

It can be observed that increasing pressure benefits the $\mathrm{CO}_{2}$ conversion rate, and this benefit is bigger for the highest pressure. It is shown that the increase between 30 and 50 
bar is much higher than between 20 and 30 bar, which can indicate that this increment can continue improving for higher pressures.

High pressure conditions have been reported to be beneficial to improve the reaction due to Le Châtelier's principle, achieving higher $\mathrm{CO}_{2}$ conversion ${ }^{23}$. With the aim of working at higher pressures, a new carbon dioxide flow controller (Cori-Flow, Bronkhorst) was bought to enable work with $\mathrm{CO}_{2}$ also in supercritical conditions when pressure and temperature are above 73 bar and $31{ }^{\circ} \mathrm{C}$. The introduction of this new flow controller allowed to increase the pressure up to 100 bar, and to study the reaction in these new conditions keeping all the other variables constant as in previous experiments (Figure 2.12).

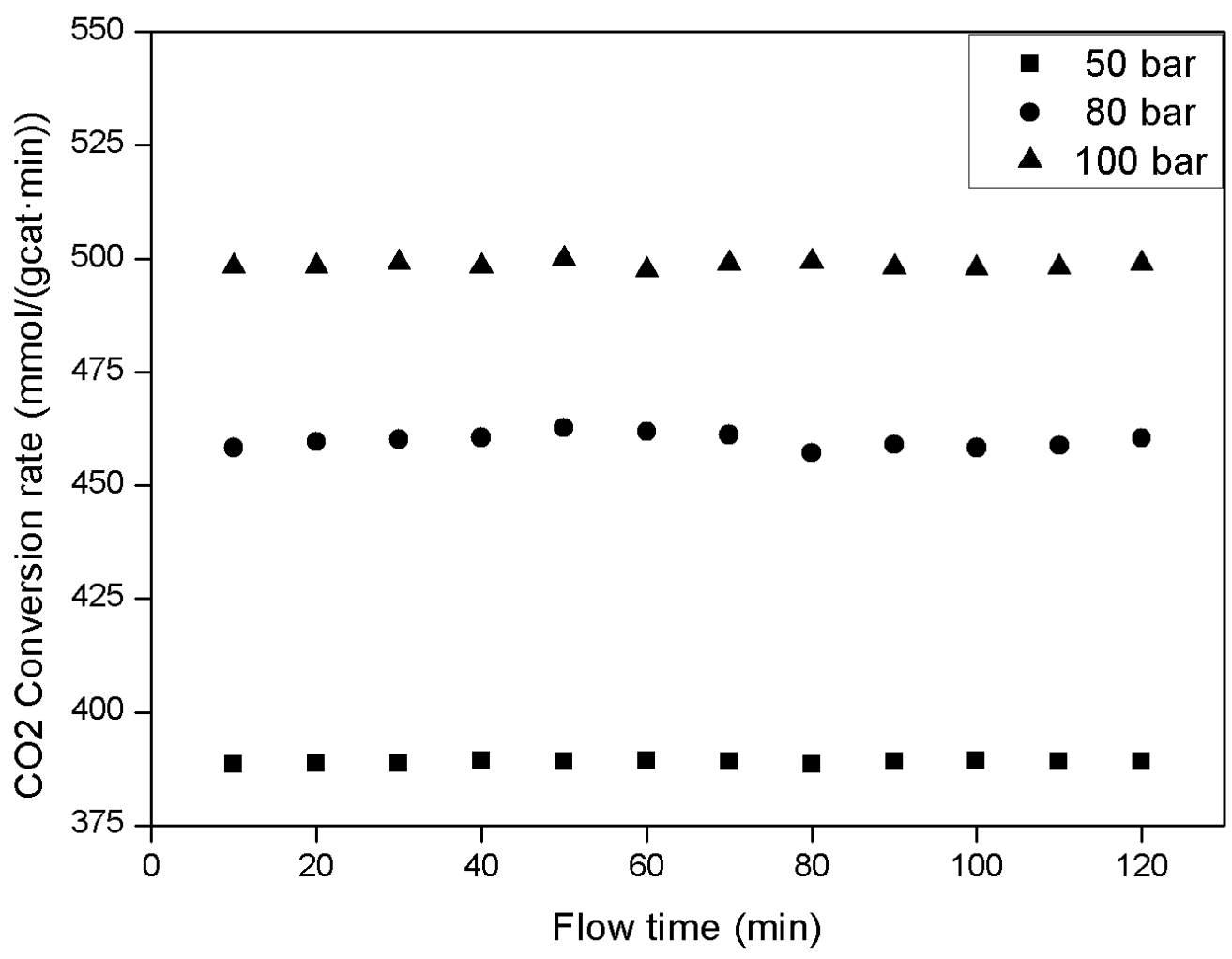

Figure 2.12. $\mathrm{CO}_{2}$ hydrogenation at high pressures.

These results continue showing an improvement in the $\mathrm{CO}_{2}$ conversion rate, particularly important after working in supercritical conditions for carbon dioxide. This large benefit 
continues to be achieved until reaching 100 bar, which is the maximum pressure the experimental setup allows to work.

\section{Conclusions}

Carbon dioxide hydrogenation has been performed using a plasmonic catalyst composed of copper and zinc oxide supported in transparent silica aerogels. This nanocomposite has been impregnated in 0.5 ID glass microreactors with good adherence to be used to perform the reaction in gas phase.

The experimental setup built allowed precise control of the pressure, temperature and gases flow to study their influence in the reaction. The amount of catalyst loaded in the aerogel was also studied as a variable to improve the process.

Changes in temperature and gases flow did not affect $\mathrm{CO}_{2}$ conversion rates, not being useful to improve the process. An increase in the amount of catalyst was negative for the goal of improving the $\mathrm{CO}_{2}$ conversion rate, achieving better results for the smallest amount of catalyst.

The key parameter to enhance the results has been proved to be the pressure. Increasing pressure up to 50 bar improved $\mathrm{CO}_{2}$ conversion rate considerably, even though overpassing the critical point multiplied the benefit for the $\mathrm{CO}_{2}$ conversion rate. While other parameters provided a slight improvement, pressure improved up to $31 \%$ the $\mathrm{CO}_{2}$ conversion rate obtained.

\section{References}

1. Parmesan, C., Yohe, G., A globally coherent fingerprint of climate change impacts across natural systems. Nature, 2003, 421, 37-42. 
2. Cox, P. M., et al., Acceleration of global warming due to carbon-cycle feedbacks in a coupled climate model. Nature, 2000, 408, 184 -187.

3. Centi, G., Quadrelli, E. A., Perathoner, S., Catalysis for $\mathrm{CO}_{2}$ conversion: A key technology for rapid introduction of renewable energy in the value chain of chemical industries. Energy \& Environmental Science, 2013, 6, 1711-1731.

4. Centi, G., Perathoner, S., Opportunities and prospects in the chemical recycling of carbon dioxide to fuels. Catalysis Today, 2009, 148, 191-205.

5. Qu, Y., Duan, X., Progress, challenge and perspective of heterogeneous photocatalysts. Chemical Society Reviews, 2013, 42, 2568-2580

6. Linic, S., Christopher, P., Ingram, D.B., Plasmonic-metal nanostructures for efficient conversion of solar to chemical energy. Nature Materials, 2011 10, 911-921.

7. Lee, K.-S., El-Sayed, M. A., Gold and silver nanoparticles in sensing and imaging: Sensitivity of plasmon response to size, shape, and metal composition. Journal of Physical Chemistry B, 2006, 110, 19220-19225.

8. Khanna, P. K., et al., Synthesis and characterization of copper nanoparticles. Materials Letters, 2007, 61, 4711-4714.

9. Studt, F., et al., The Mechanism of $\mathrm{CO}$ and $\mathrm{CO}_{2}$ Hydrogenation to Methanol over $\mathrm{Cu}-$ Based Catalysts. ChemCatChem, 2015, 7, 1105-1111.

10. Darugar, Q., et al., Size-dependent ultrafast electronic energy relaxation and enhanced fluorescence of copper nanoparticles. Journal of Physical Chemistry B, 2006, 110, 143149.

11. Tisseraud, $\mathrm{C}$., et al., The $\mathrm{Cu}-\mathrm{ZnO}$ synergy in methanol synthesis from $\mathrm{CO}_{2}$, Part 2: Origin of the methanol and $\mathrm{CO}$ selectivities explained by experimental studies and a sphere contact quantification model in randomly packed binary mixtures on $\mathrm{Cu}-\mathrm{ZnO}$ coprecipitate catalysts. Journal of Catalysis, 2015, 330, 533-544.

12. Anicic, B., Trop, P., Goricanec, D., Comparison between two methods of methanol production from carbon dioxide. Energy, 2014, 77, 279-289. 
13. Das, S., Srivastava, V.C., Microfluidic-based photocatalytic microreactor for environmental application: A review of fabrication substrates and techniques, and operating parameters. Photochemical and Photobiological Sciences, 2016, 15, 714-730.

14. Shlyakhtina, A. V., Oh, Y.-J., Transparent $\mathrm{SiO}_{2}$ aerogels prepared by ambient pressure drying with ternary azeotropes as components of pore fluid. Journal of NonCrystalline Solids, 2008, 354, 1633-1642.

15. Navarrete, et al., Novel windows for "solar commodities": A device for $\mathrm{CO}_{2}$ reduction using plasmonic catalyst activation. Faraday Discussions, 2015, 183, 249-259.

16. Tan, Z. Y., et al., Nanostructured $\mathrm{Cu} / \mathrm{ZnO}$ coupled composites: Toward tunable $\mathrm{Cu}$ nanoparticle sizes and plasmon absorption. The Journal of Physical Chemistry C, 2013, 117, 10780-10787.

17. Sanz-Moral, L. M., et al., View cell investigation of silica aerogels during supercritical drying: Analysis of size variation and mass transfer mechanisms. The Journal of Supercritical Fluids, 2014, 92, 24-30.

18. Smitha, S., et al., Effect of aging time and concentration of aging solution on the porosity characteristics of subcritically dried silica aerogels. Microporous and Mesoporous Materials, 2006, 91, 286-292.

19. NASA, What Wavelength Goes With a Color?, http://science-edu.larc.nasa.gov/EDDOCS/Wavelengths_for_Colors.html)

20. Al-Oweini, R., El-Rassy, H., Synthesis and characterization by FTIR spectroscopy of silica aerogels prepared using several $\mathrm{Si}(\mathrm{OR})_{4}$ and $\mathrm{R}^{\prime \prime} \mathrm{Si}\left(\mathrm{OR}^{\prime}\right)_{3}$ precursors. Journal of Molecular Structure, 2009, 919, 140-145.

21. Al-Oweini, R., El-Rassy, H., Surface characterization by nitrogen adsorption of silica aerogels synthesized from various $\mathrm{Si}(\mathrm{OR})_{4}$ and $\mathrm{R}^{\prime \prime} \mathrm{Si}\left(\mathrm{OR}^{\prime}\right)_{3}$ precursors. Applied Surface Science, 2010, 257, 276-281.

22. Martínez-Suárez, L., et al., Reaction Network of Methanol Synthesis over $\mathrm{Cu} / \mathrm{ZnO}$ Nanocatalysts ACS Catalysis, 2015, 5, 4201-4218.

23. Gaikwad, R., Bansode, A., Urakawa, A., High-pressure advantages in stoichiometric hydrogenation of carbon dioxide to methanol. Journal of Catalysis, 2016, 343, 127-13 


\section{CHAPTER 3}

Enhanced light activation of the catalyst 



\section{Introduction}

The industrial revolution has brought many benefits for the humanity, although it has had many adverse consequences for the planet. Carbon dioxide concentration in the atmosphere has grown from $277 \mathrm{ppm}$ before industrial revolution to more than 402 ppm nowadays ${ }^{1}$, and this increase is expected to exceed $500 \mathrm{ppm}$ at the end of the century. Carbon dioxide is one of the main responsible of climate change and the increase of its emissions has had dramatic consequences for the planet, such as ocean acidification, global warming and polar ice sheets melting with rise of sea level ${ }^{2}$.

In order to reduce carbon dioxide concentration in the atmosphere there are three possible ways: the direct reduction of $\mathrm{CO}_{2}$ emissions; its capture and storage; or the utilization of the $\mathrm{CO}_{2}{ }^{3}$. Among these possibilities, $\mathrm{CO}_{2}$ utilization can give added value to the process by transforming $\mathrm{CO}_{2}$ into useful products that make the process economically viable. $\mathrm{CO}_{2}$ can be transformed into methane, dimethyl ether, methanol or formic acid, among others ${ }^{4}$. Global methanol demand has reached 70 million metric tons, which opens the possibility to transform $\mathrm{CO}_{2}$ into a highly demanded product. Methanol has applications in the chemical industry, and it is also a valuable fuel ${ }^{5}$. Methanol has been considered in the last few years as a good opportunity for energy storage, showing advantages compared with hydrogen storage due to its better handling and less risk because it is liquid at ambient conditions. If this transformation to methanol is performed using solar energy, methanol can be considered as a solar commodity ${ }^{6}$, opening the possibility to avoid problems connected to the energy intermittence associated with renewable energies. 
The transformation of carbon dioxide in order to produce methanol is commonly performed at industry by means of hydrogenation. Carbon dioxide hydrogenation is a reaction intensively studied for a long time ${ }^{7}$, mainly with the goal of methanol production. In the study of the reaction, heterogeneous catalysts have had a great importance in order to increase the selectivity and conversion of the process, and to decrease pressure and temperature conditions to cut down on the energy consumption in the reaction ${ }^{8}$. However, performing carbon dioxide hydrogenation with renewable energies is still a challenge as more efficient processes are required.

Carbon dioxide hydrogenation has been commonly performed using copper based catalysts. Copper has special properties that increase its reactivity, including the formation of multiple oxidation states ${ }^{9}$. Furthermore, copper nanoparticles exhibit surface plasmon resonance (SPR) properties $^{10}$, such as other metals like silver or gold. These SPR properties allow to increase the light absorbed by copper nanoparticles at a wavelength around $580-600 \mathrm{~nm}$ in the visual range of the spectrum. SPR phenomenon can be used to enhance the efficiency of the photocatalytic process and to improve the carbon dioxide hydrogenation using solar energy.

Copper is usually combined with zinc oxide to create a synergy that benefits the reaction. This bimetallic catalyst has been deeply studied and it has been demonstrated that active sites for the hydrogenation appear in the intersection of both materials ${ }^{11}$. For this reason, developing a synthesis method that allows to deposit discrete nanoparticles onto zinc oxide has a great importance to maximize the contact area between copper and zinc oxide creating the maximum number of active sites possible. 
Following the method proposed by Tan et al (2013) ${ }^{12}$ zinc oxide nanorods have been synthesized in a previous work $^{13}$, depositing in a second step copper nanoparticles on the surface of the nanorods. However, this amount of copper has been shown to be small compared with the copper nanoparticles that are not correctly deposited, opening the possibility to improve the efficiency of the process by increasing the amount of copper deposited onto $\mathrm{ZnO}$ nanorods. A new experimental method is going to be developed in this work in order to ensure the aim proposed.

After the synthesis of the bimetallic catalyst, it is also important the selection of the support to use the solid catalyst in a gas phase reaction. Photocatalytic reactions require a support that absorb the minimum light possible in order to ensure the catalyst is activated by light ${ }^{14}$. High surface areas are also needed to load enough catalyst on the support to perform the reaction.

Silica aerogels are mesoporous transparent materials that provide elevated surface areas, and they also ensure inertness avoiding unwanted reactions. These properties make them suitable for heterogeneous catalytic processes ${ }^{15}$.

Before performing the reaction by means of solar energy, light- emitting diodes (LEDs) are used as source of light energy to activate the catalyst. The reactor configuration must provide the best light distribution in order to enhance the process efficiency. Microreactors have large surface to volume ratios, property that improves the light uniformity through the entire reactor ${ }^{16}$. The use of glass microreactors diminishes light interferences and provides high stress resistance for 
high pressure operation as well as chemical resistance. Therefore, glass reactors were chosen to perform the reactions.

With all this information, the objective of this work is the development of a novel synthesis method to produce copper nanoparticles deposited onto $\mathrm{ZnO}$ nanorods that absorb a higher amount of visual light. In order to achieve this goal, it is necessary a more efficient reduction of copper and a higher amount of copper nanoparticles deposited onto the nanorods. When the synthesis method has been correctly developed and the light absorbance has been measured, the catalyst will be impregnated inside glass microreactors and carbon dioxide hydrogenation will be performed with the aim of maximizing $\mathrm{CO}_{2}$ conversion rate.

\section{Experimental methods}

\subsection{Reagents}

The chemicals used during this stage were: Zinc acetate dihydrate (>98\%), oleylamine (70\%), tetramethyl orthosilicate (98\%), ammonia (28-30\%) and hydrazine were purchased from Sigma-Aldrich. Ethylene glycol (99.5\%) (Merck). Methanol (99.8\%) was purchased from Panreac. Copper chloride dehydrate was purchased from Fluka.

\subsection{Synthesis of $\mathrm{ZnO} / \mathrm{Cu}$ catalyst}

First, $\mathrm{ZnO}$ were synthesized following the method proposed by Zhang et al $(2007)^{17}$. In this method (Figure 3.1), oleylamine is used as the capping and the reducing agent at the same time. To produce $\mathrm{ZnO}$ in nanorods form, $3 \mathrm{mmol}$ of zinc acetate were mixed with $1.3 \mathrm{ml}$ of oleylamine in a three necked flask. Both 
reagents were first degassed to remove impurities from oleylamine, heating the mixture at $80^{\circ} \mathrm{C}$ for 45 min under vacuum atmosphere. After that, the system was heated up to $220^{\circ} \mathrm{C}$ for $15 \mathrm{~min}$, and subsequently cooled quickly to stop the reaction. The final product was removed from the three necked flask with the help of $10 \mathrm{ml}$ of ethanol and magnetic stirring. With the aim of isolating the $\mathrm{ZnO}$ nanorods produced, they were centrifuged at $5000 \mathrm{rpm}$ and washed twice with 5 $\mathrm{ml}$ of ethanol. A little amount of hexane was also added to the ethanol in order to help with the removal of the oleylamine that could remain in the sample.

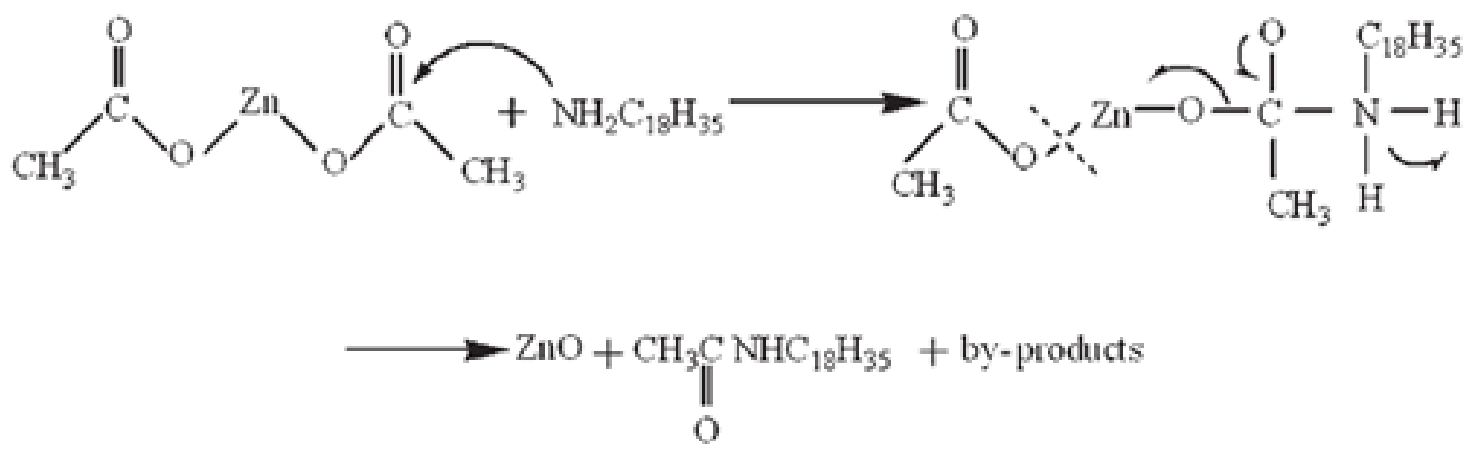

Figure 3.1. Mechanism of $\mathrm{ZnO}$ synthesis (Tan et al., The Journal of Physical Chemistry C, 2013).

$\mathrm{ZnO}$ nanorods prepared above were then redispersed in $20 \mathrm{ml}$ of ethylene glycol, by sonication for one hour followed by stirring under room conditions overnight. In a different vessel, a second solution of copper chloride was prepared by adding $4 \mathrm{ml}$ of ethylene glycol and sonicating for one hour. Both solutions were mixed under stirring at low temperature $\left(50^{\circ} \mathrm{C}\right)$ for $5 \mathrm{~min}$. After this, hydrazine monohydrate was added in order to produce small copper nanoparticles as a result of a fast reduction. This reactant can also affect $\mathrm{ZnO}$ nanorods if it is added in excess, deforming the nanorods after completing the reduction of copper. For this reason, the amount of hydrazine was adjusted to find a proportion (hydrazine: 
copper chloride) that managed to keep $\mathrm{ZnO}$ nanorods with a high amount of copper nanoparticles deposited onto. After this, the composite was washed three times with isopropanol, centrifuged during 10 minutes at 6000rpm and isolated from the mixture.

\subsection{Synthesis and impregnation of silica aerogels}

The silica gels were synthetized following the method used by Sanz-Moral et al $(2014)^{18}$. The precursors used were tetramethyl orthosilicate (TMOS), methanol, water and ammonia in a $1: 2.3: 3.84: 0.12$ molar ratio. The amount of ammonia was adjusted previously to get the right gelation time in order to avoid precipitation of the catalyst.

First, methanol was added to the catalyst nanoparticles under sonication for one hour to create a colloidal suspension. After this, the colloidal suspension was mixed with TMOS in a small pot and stirred for $15 \mathrm{~min}$. At the same time, a second solution with water and ammonia was prepared in a different beaker and also stirred for $10 \mathrm{~min}$. Both pots were closed to avoid TMOS and ammonia evaporation during the process. Then, both solution were mixed and the gelation process started. The mixture remained in a liquid state for almost one minute. In this time the liquid gel was impregnated inside the glass microreactors using a syringe. When the gelation process finished, the hydrogel with the catalyst nanoparticles inside was correctly synthetized showing great adherence to the walls of the microchannels.

The silica aerogel was distributed homogeneously through the entire length of the reactor (15 min) avoiding empty spaces or air bubbles (Figure 3.2). 


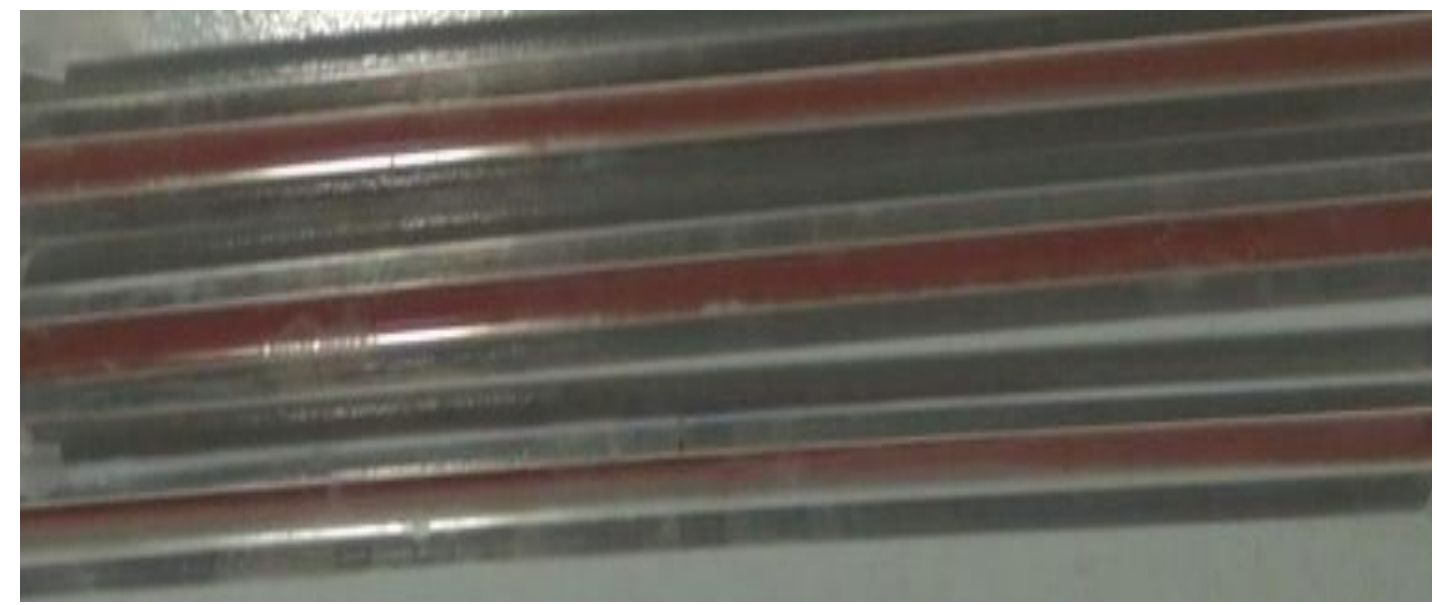

Figure 3.2. Catalyst impregnation inside glass microchannels.

After that, the hydrogel was aged to remove water from the structure. In this step, the microreactors were placed in a vessel filled with methanol for a week, renewing the methanol twice during the week. Aging enhances the strength and stiffness of the wet gel and is critical to prevent the pore collapse of gels ${ }^{19}$.

Finally, aerogels were synthesized drying these alcogels with supercritical carbon dioxide. With this purpose, the microreactors containing the alcogels were placed in a high pressure vessel and filled with methanol. The system was heated over the critical temperature of $\mathrm{CO}_{2}\left(31.1^{\circ} \mathrm{C}\right)$ and pressurized above the critical pressure (73.8 bar). In the drying process supercritical conditions must be kept during the complete experience, because only $\mathrm{SC} \mathrm{CO}_{2}$ can dry the methanol from the silica structure without breaking $\mathrm{it}^{18}$. Because of it, the conditions were stablished in $45^{\circ} \mathrm{C}$ and 120 bar in order not to be close to lose the supercritical conditions. During the process, drying was performed in cycles where the $\mathrm{CO}_{2}$ was inside the high pressure vessel for one hour, and renewed between each cycle with fresh SC $\mathrm{CO}_{2}$. After 5 cycles no more methanol remained in the system and the silica 
aerogels with the catalyst inside kept great adherence to the walls of the microchannels.

\subsection{Reaction experimental plant}

An experimental setup to perform the carbon dioxide hydrogenation has been built up. This experimental plant was used previously with good results ${ }^{13}$.

The experimental plant consisted on three differenced parts. In the first part, both gases were mixed in a $3: 1$ proportion, using $1 \mathrm{ml} / \mathrm{min}$ of $\mathrm{H}_{2}$ and $0.33 \mathrm{ml} / \mathrm{min}$ of $\mathrm{CO}_{2}$ during the experiments. Gas flows were controlled by two different flow mass controllers (EL-Flow F-200, Bronkhorst) with ranges up to $1 \mathrm{ml} / \mathrm{min}$.

After the flows were correctly adjusted, the gas mixture was driven to the second part of the experimental setup. In this point, both gases were heated in an oven up to $50{ }^{\circ} \mathrm{C}$ before starting the reaction. Pressure was controlled by a pressure controller (EL-Press series, Bronkhorst). The microreactor (Schott Duran, USA) consisted on a glass capillary with an internal diameter of $0.5 \mathrm{~mm}$ and external diameter of $5 \mathrm{~mm}$. A system with 36 LEDs was designed to wrap the entire microreactor with the aim of illuminating the catalyst in a completely homogeneous form.

Finally, the last part of the setup was used to analyze the outlet gases. A Micro Gas Chromatograph (CP-4900, Varian) was used with this purpose. In order to work with this equipment, the gas stream was depressurized to use 3 bar as injection pressure for the microGC. A filter (Genie filter 170) was also placed to remove water generated in the reaction before the analysis. Two different columns were used to measure the gas stream: a poraplot $10 \mathrm{~m}$ and a $5 \mathrm{~A}$ molsieve. 


\subsection{Catalyst characterization}

Transmission Electron Microscopy was performed with a JEOL JEM-2100F UHR system. Light absorbance of the catalyst was studied using a UV-Vis Spectrophotometer (Shimadzu UV 2550). Fourier Transform Infrared Spectroscopy was carried out in a FTIR model TENSOR from Bruker. BET surface area and the nitrogen isothermal adsorption - desorption curve were calculated with an Accelerated Surface Area and Porosimetry System (ASAP 2020).

\section{Results and discussion}

\subsection{Catalyst synthesis and characterization}

The influence of hydrazine on the synthesis method was studied, testing if it could improve the $\mathrm{Cu}$ nanoparticles deposition and how it affected the $\mathrm{ZnO}$ nanorods formed previously. Firstly, a molar relation 10:1 hydrazine to copper chloride was tested at various $\mathrm{Zn}$ to $\mathrm{Cu}$ feed ratios. Light absorption of this bimetallic catalyst was checked by UV-Vis Spectrophotometry in order to analyse if copper nanoparticles created were absorbing light correctly (Figure 3.3).

In this figure, it can be seen that copper nanoparticles showed a peak around 600 $\mathrm{nm}$, and the area of this peak was expanded when the amount of copper was increased. 


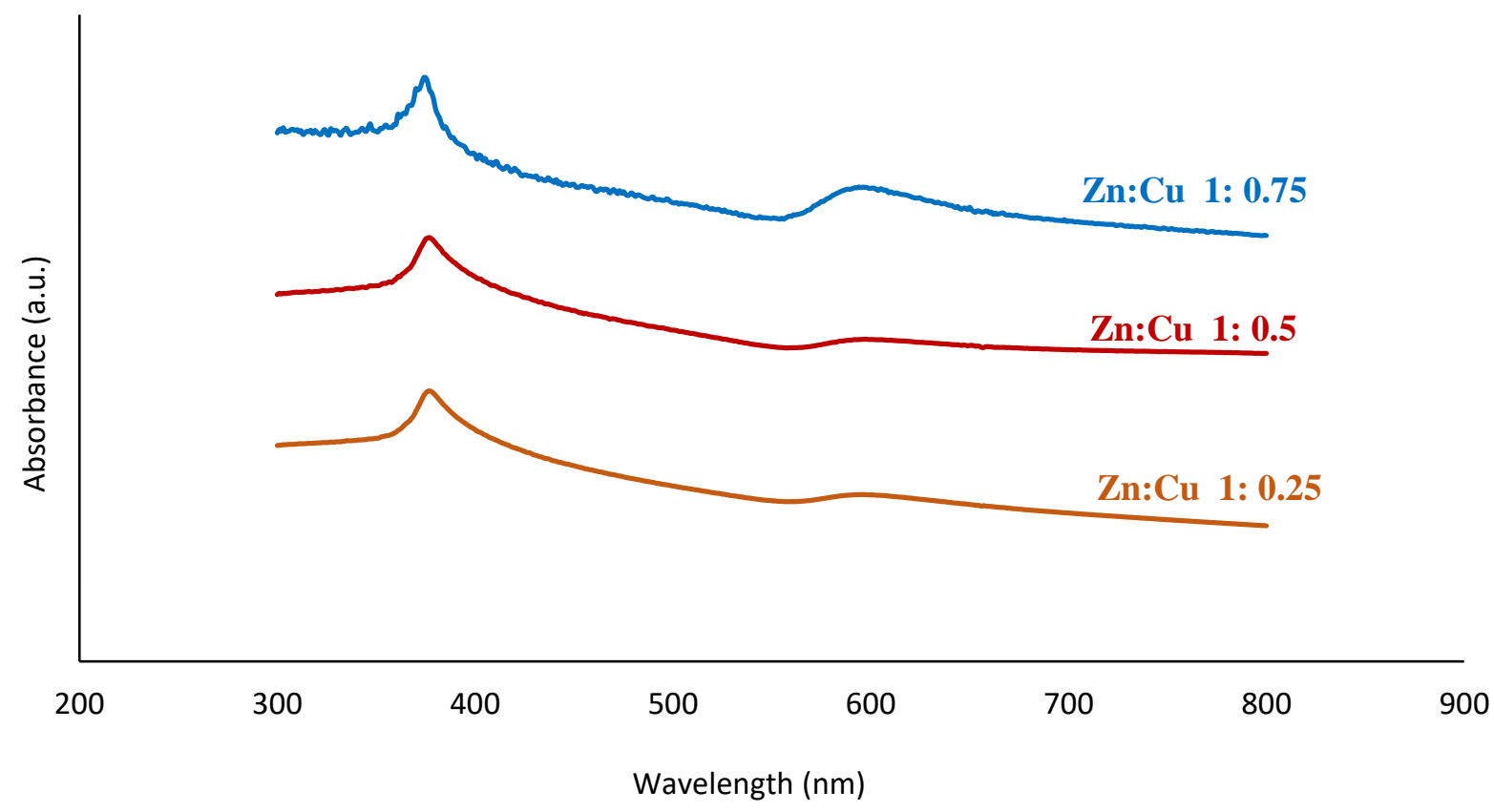

Figure 3.3. UV-Vis absorption spectra of $\mathrm{ZnO} / \mathrm{Cu}$ catalyst for different $\mathrm{Zn}$ to $\mathrm{Cu}$ feed ratios.

However, when Transmission Electron Microscopy was used to check the correct formation of $\mathrm{ZnO}$ nanorods (Figure 3.4), the results were not as expected.
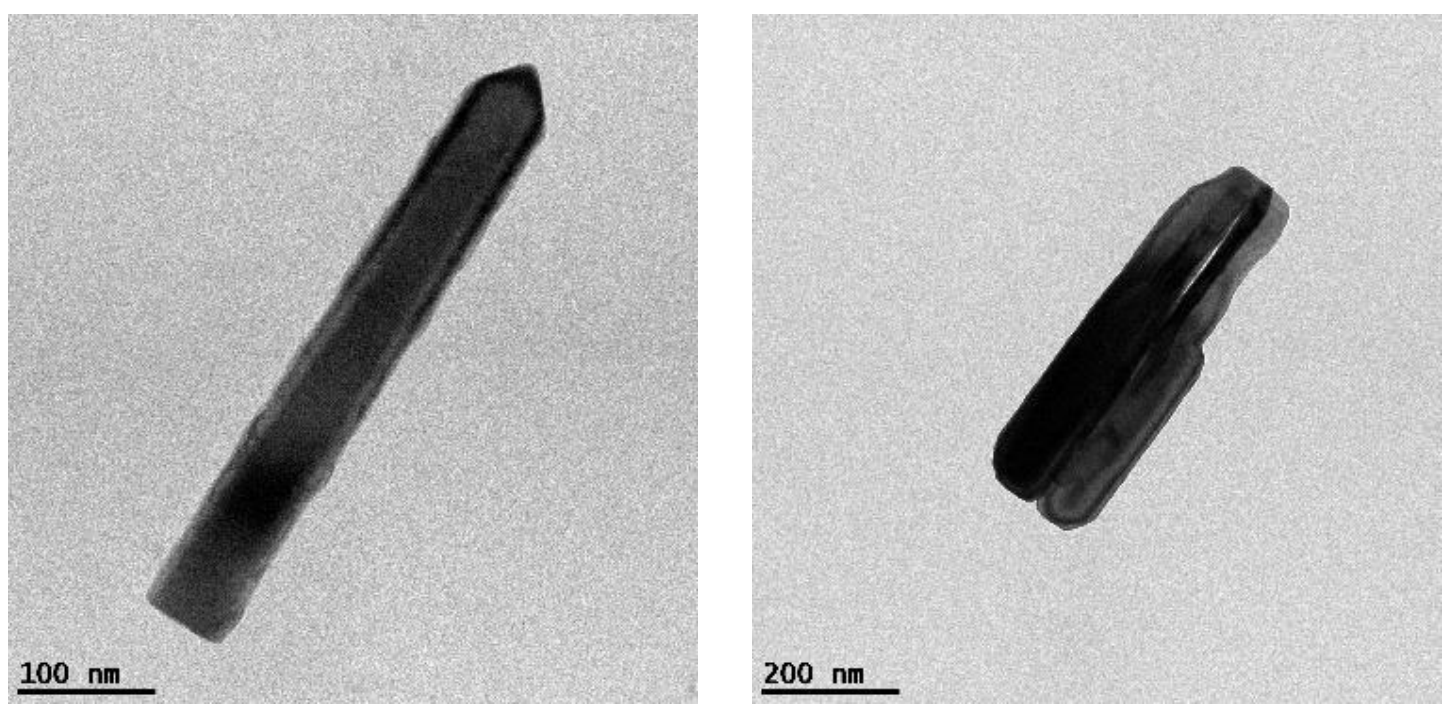

Figure 3.4. TEM images of $\mathrm{ZnO}$ nanorods before hydrazine treatment (left) and after hydrazine (right).

$\mathrm{ZnO}$ nanoparticles before using hydrazine showed appropriate rod shape as it was the aim of the synthesis. On the other hand, after hydrazine treatment this shape was deformed, 
disappearing the regular form of their planes. Moreover, no copper nanoparticles were found on the surface of the $\mathrm{ZnO}$ structure. Copper nanoparticles were correctly reduced with the use of hydrazine, absorbing light as it was desired. However, they were not found in the vicinity of the $\mathrm{ZnO}$ structures, which made it impossible to use this catalyst for carbon dioxide hydrogenation, as there were no intersection between zinc oxide and copper nanoparticles where it should be performed the reaction ${ }^{11}$.

Only for the lowest relation $\mathrm{Zn}: \mathrm{Cu}(1: 0.25)$ some $\mathrm{ZnO}$ nanoparticles were found keeping a nanorod shape. Lowest amount of copper corresponded with the lowest amount of hydrazine used in the process. This fact demonstrated that hydrazine could be used without deforming $\mathrm{ZnO}$ nanorods, but the amount should be adjusted in order to reduce copper nanoparticles avoiding the attack on $\mathrm{ZnO}$ structures. With this purpose several experiments were performed, and the optimal hydrazine amount was established for a 3:1 proportion (hydrazine to copper chloride). The structures produced were studied again by TEM analysis (Figure 3.5).
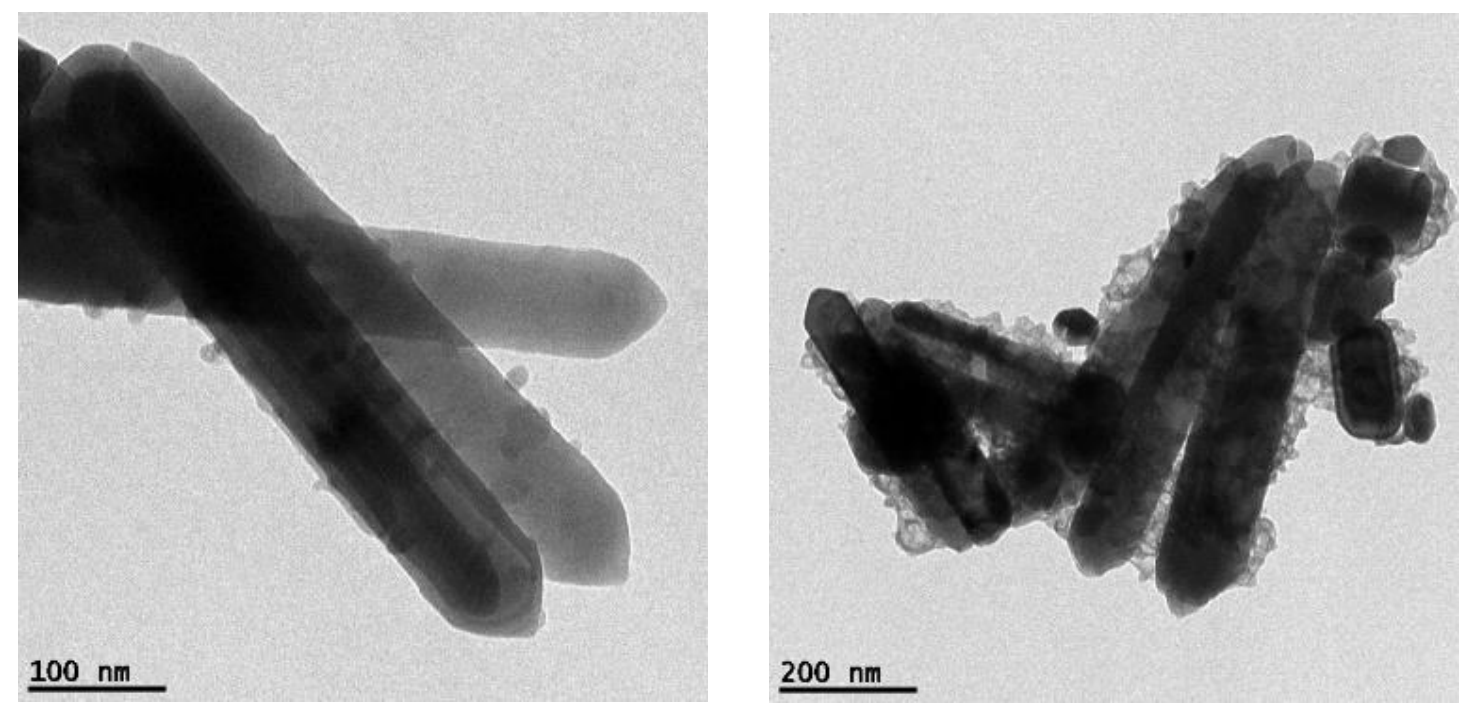

Figure 3.5. TEM images of copper nanoparticles deposited onto $\mathrm{ZnO}$ nanorods in previous work (left) and with the use of hydrazine (right). 
This analysis showed that $\mathrm{ZnO}$ nanorods kept their shape after the use of hydrazine. At the same time, this amount of hydrazine was enough to reduce copper nanoparticles that were correctly deposited around the $\mathrm{ZnO}$ structure. It can be clearly seen that the amount of copper deposited raised in a considerable way, increasing the efficiency of the synthesis method and creating a bimetallic catalyst with many more active sites to perform the carbon dioxide hydrogenation. Light absorption of the new bimetallic catalyst was also studied to test if copper nanoparticles increased their light absorption (Figure 3.6).

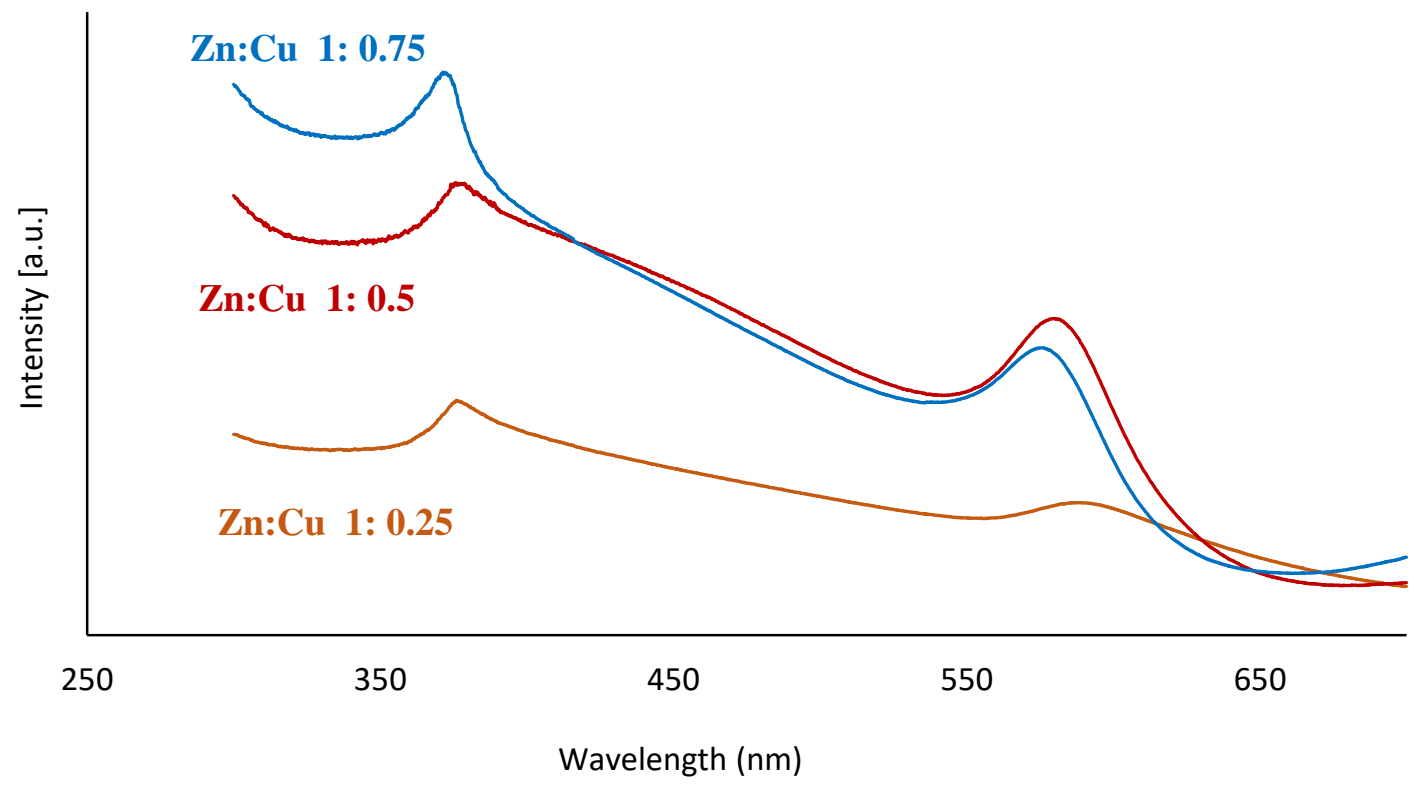

Figure 3.6. UV-Vis absorption spectra of bimetallic catalyst for a 3:1 proportion (Hydrazine: $\mathrm{Cu}$ ).

It can be seen that light absorption of copper nanoparticles has been increased, achieving the best results for 1:0.5 and 1:0.75 $\mathrm{Zn}$ to $\mathrm{Cu}$ feed ratios. $\mathrm{ZnO}$ peak remained constant at $370 \mathrm{~nm}$, and $\mathrm{Cu}$ nanoparticles exhibited a peak around 600 $\mathrm{nm}$ that was slightly shifted to the left when the amount of copper was increased. As the highest light absorption of copper nanoparticles was obtained for the 1:0.5 
$\mathrm{Zn}$ to $\mathrm{Cu}$ feed ratio, this was selected as the optimum in order to perform the carbon dioxide hydrogenation.

The bimetallic catalyst characterization was completed by using-Ray Diffraction analysis (Figure 3.7).

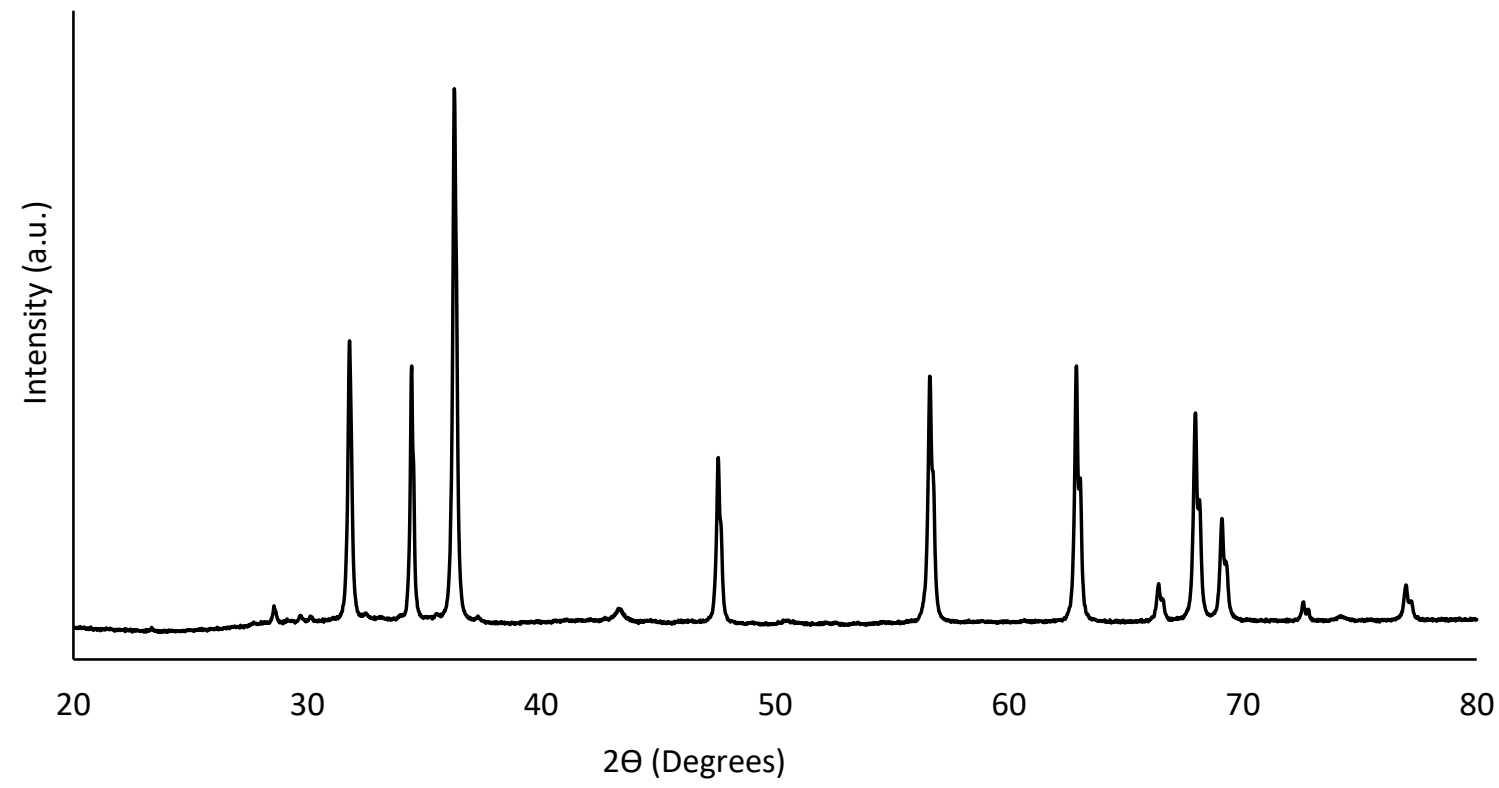

Figure 3.7. XRD pattern of the bimetallic catalyst.

In this analysis $\mathrm{ZnO}$ planes were clearly identified at $2 \theta=31.7^{\circ}(100), 2 \theta=34.4^{\circ}$ (002), $2 \theta=36.3^{\circ}(101), 2 \theta=47.6^{\circ}(102), 2 \theta=56.6^{\circ}(110), 2 \theta=62.8^{\circ}(103)$ and $2 \theta=68^{\circ}(112)^{20}$. Furthermore, copper main plane (111) could be observed at $44^{\circ 21}$. When the bimetallic catalyst was impregnated inside the silica aerogel, XRD analysis was repeated to observe if these planes could also be identified (Figure 3.8). 


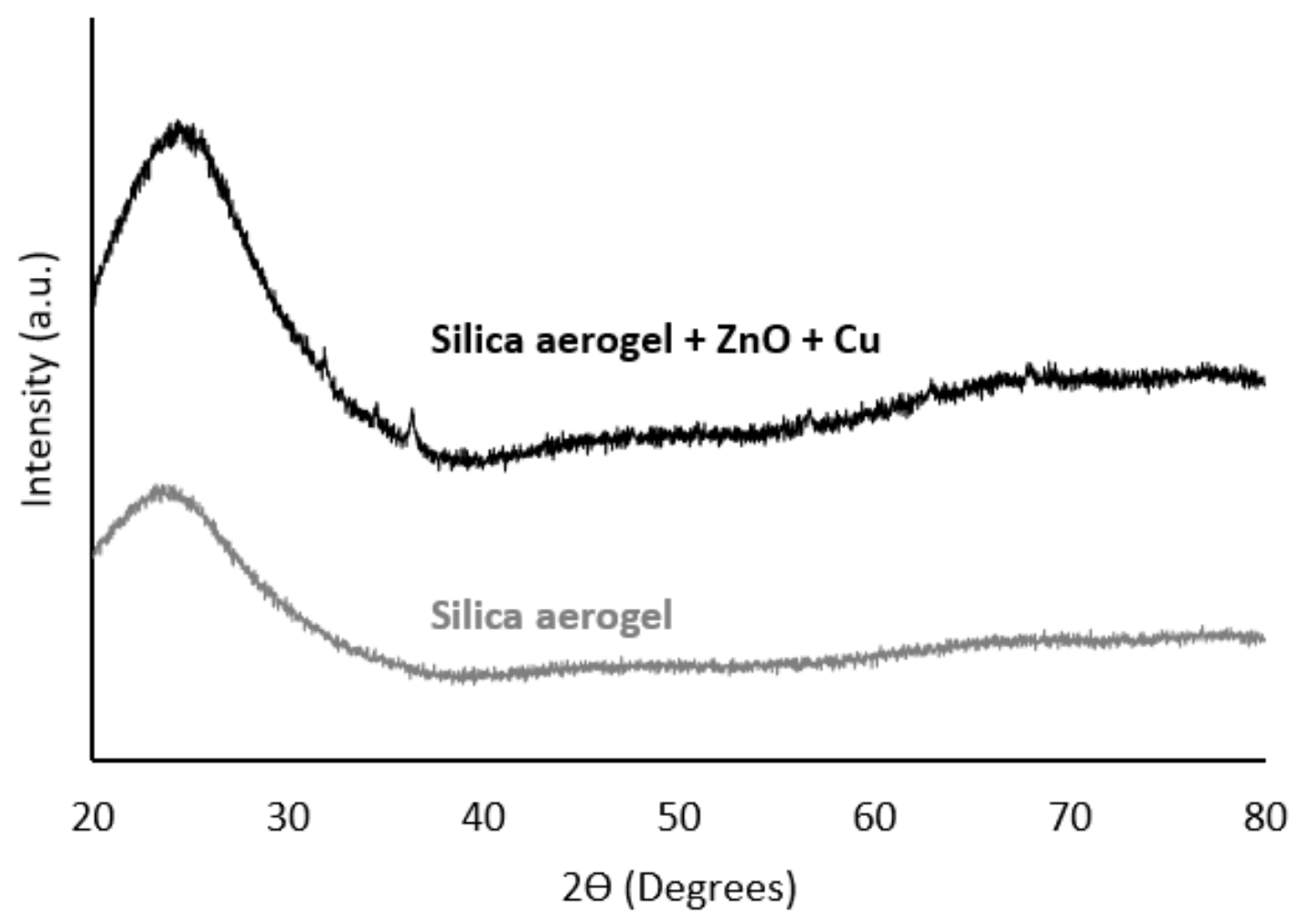

Figure 3.8. XRD pattern of silica aerogel and silica aerogel with the bimetallic catalyst impregnated.

Silica aerogel exhibited just one amorphous peak around $2 \theta=25^{\circ}$, while adding the bimetallic catalyst to the structure did not have a big influence due to the low proportion in the structure. Even so, some of the planes of $\mathrm{ZnO}$ could be observed, such as plane 101 at $2 \theta=36.3^{\circ}$.

In order to complete the nanocomposite characterization, Fourier Transform Infrared Spectroscopy and BET analysis were performed to study the mesoporous structure. First, the nitrogen isotherm adsorption - desorption was used to determine the surface area and pore volume (Figure 3.9). 


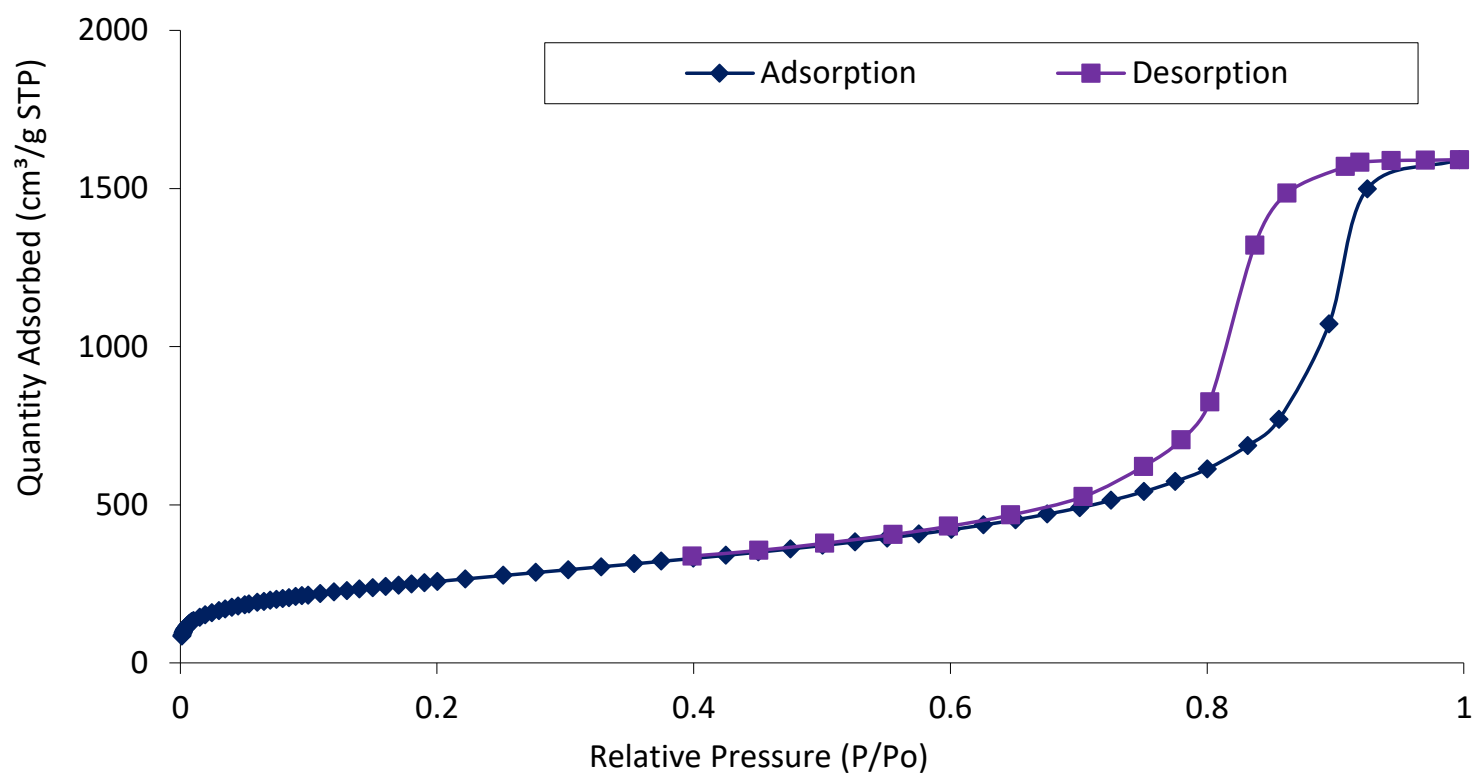

Figure 3.9. Isotherm adsorption - desorption for silica aerogels.

An isotherm curve type IV was obtained, that is common for mesoporous silica aerogels. The BET surface area for a $10 \%$ catalyst load in the aerogel was 821.1 $\mathrm{m}^{2} / \mathrm{g}$, what means a little decrease from silica aerogels without catalyst $(845.3$ $\left.\mathrm{m}^{2} / \mathrm{g}\right)$. The BJH pore volume was $2.31 \mathrm{~cm}^{3} / \mathrm{g}$.

FTIR analysis was also performed to ensure the correct formation of silica structure bonds (Figure 3.10). With a $10 \%$ catalyst load, the FTIR figure obtained was the general spectra for silica mesoporous structures ${ }^{18}$, where most important chemical bonds have been identified in the image. 


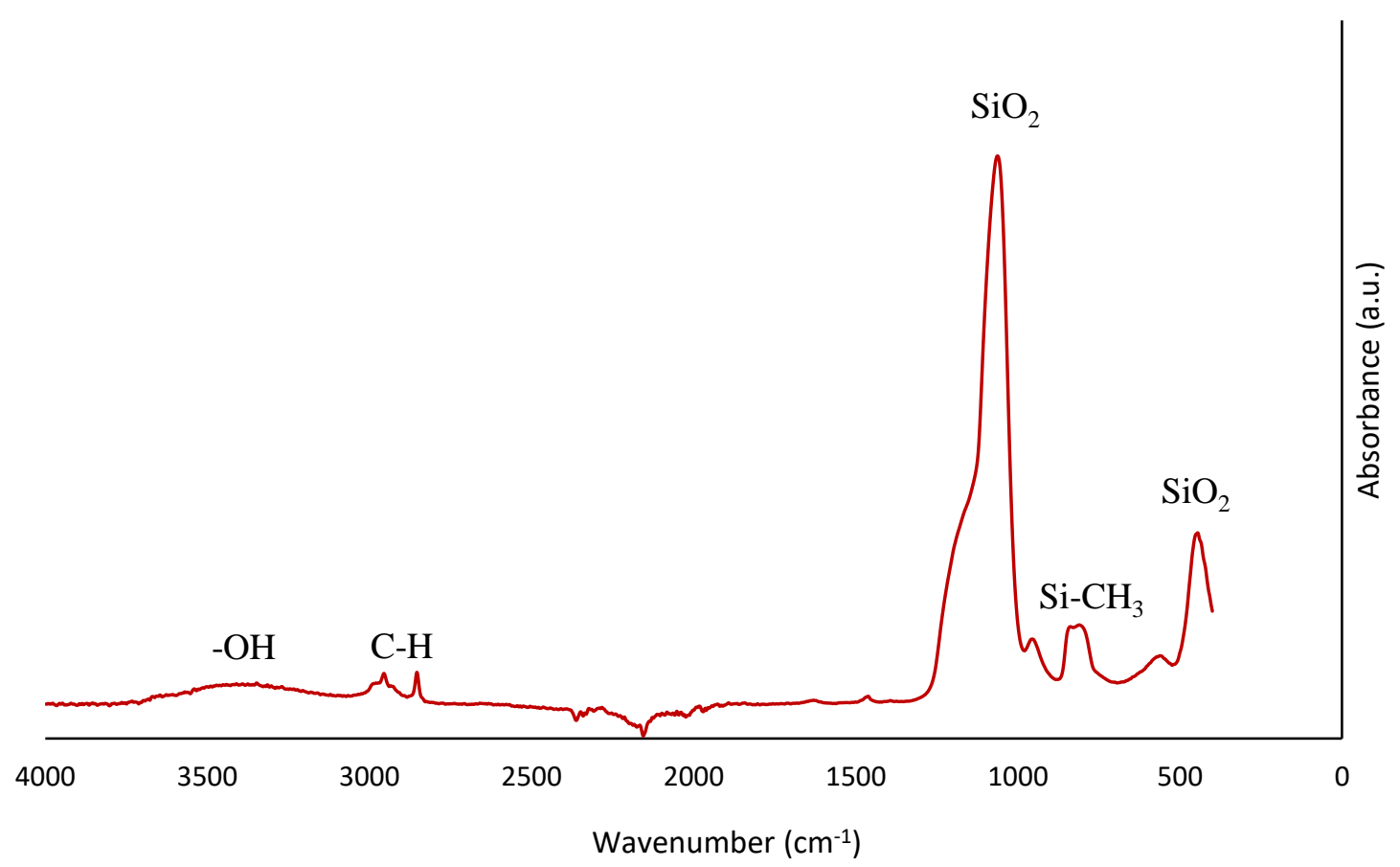

Figure 3.10. FTIR spectra of silica aerogels with catalyst loaded.

\subsection{Reaction results}

After the first proof of concept done ${ }^{13}$, and several experiments performed to study which parameters could have influence in the reaction, the pressure was identified as the key parameter to enhance the $\mathrm{CO}_{2}$ conversion rate.

With the new catalyst synthesized, it has been studied how pressure could improve the reaction. With this purpose, experiments at 20,30 and 50 bar were performed. For all the experiences the temperature was $50{ }^{\circ} \mathrm{C}$, the catalyst loaded in the aerogel was $10 \%$ in mass, and the gas flows were $1 \mathrm{ml} / \mathrm{min}$ and $0.33 \mathrm{ml} / \mathrm{min}$ for hydrogen and carbon dioxide, respectively. First, gas flows were stabilized, and when they were constant they were driven to the microreactor to begin the reaction. Outlet gas stream was analyzed every $10 \mathrm{~min}$ in order to measure the $\mathrm{CO}_{2}$ conversion rates (Figure 3.11). 


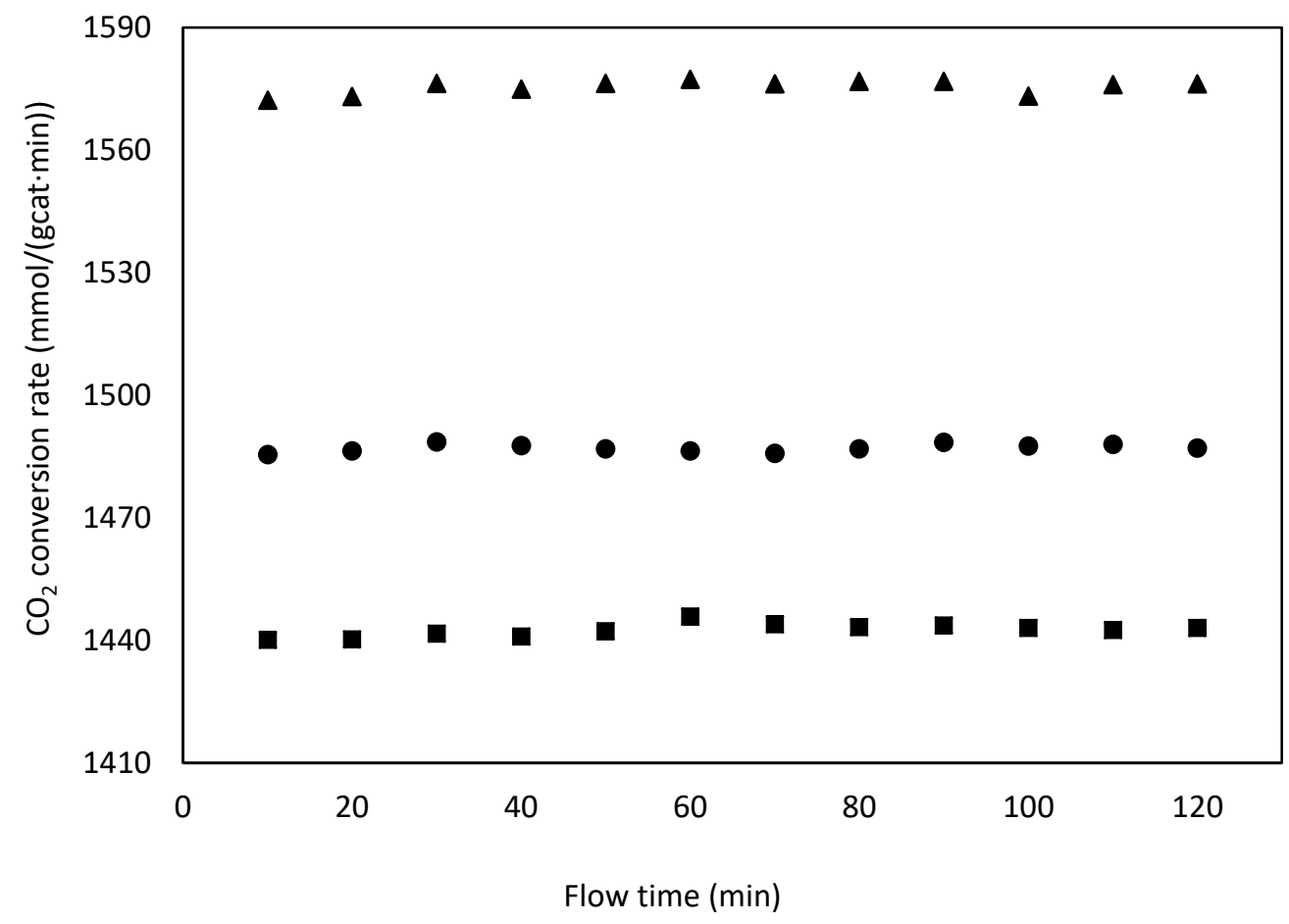

Figure 3.11. Influence of pressure in the reaction (20 bar $\boldsymbol{\varpi}, 30$ bar $\bullet, 50$ bar $\mathbf{\Delta}$ ).

It can be observed that best results were achieved for the highest pressure. The improvement obtained was almost constant among different pressures, increasing the $\mathrm{CO}_{2}$ conversion rate around $45 \mathrm{mmol} / \mathrm{g}_{\mathrm{cat}} \cdot \mathrm{min}$ every $10 \mathrm{bar}$. An increment of the pressure benefits the transformation of carbon dioxide because it moves the equilibrium to the formation of reaction products ${ }^{22}$. This linear increase was expected to continue for higher pressures, although the $\mathrm{CO}_{2}$ flow controller used in the system only allowed to work at pressures up to 50 bar.

In order to work at higher pressures a new carbon dioxide flow controller (CoriFlow, Bronkhorst) was installed in the system to work with $\mathrm{CO}_{2}$ also in supercritical conditions. A piston pump was also required to pressurize $\mathrm{CO}_{2}$ up to 100 bar and study the influence of the supercritical phase in the reaction (Figure 3.12). Other variables remained constant as previous experiments. 


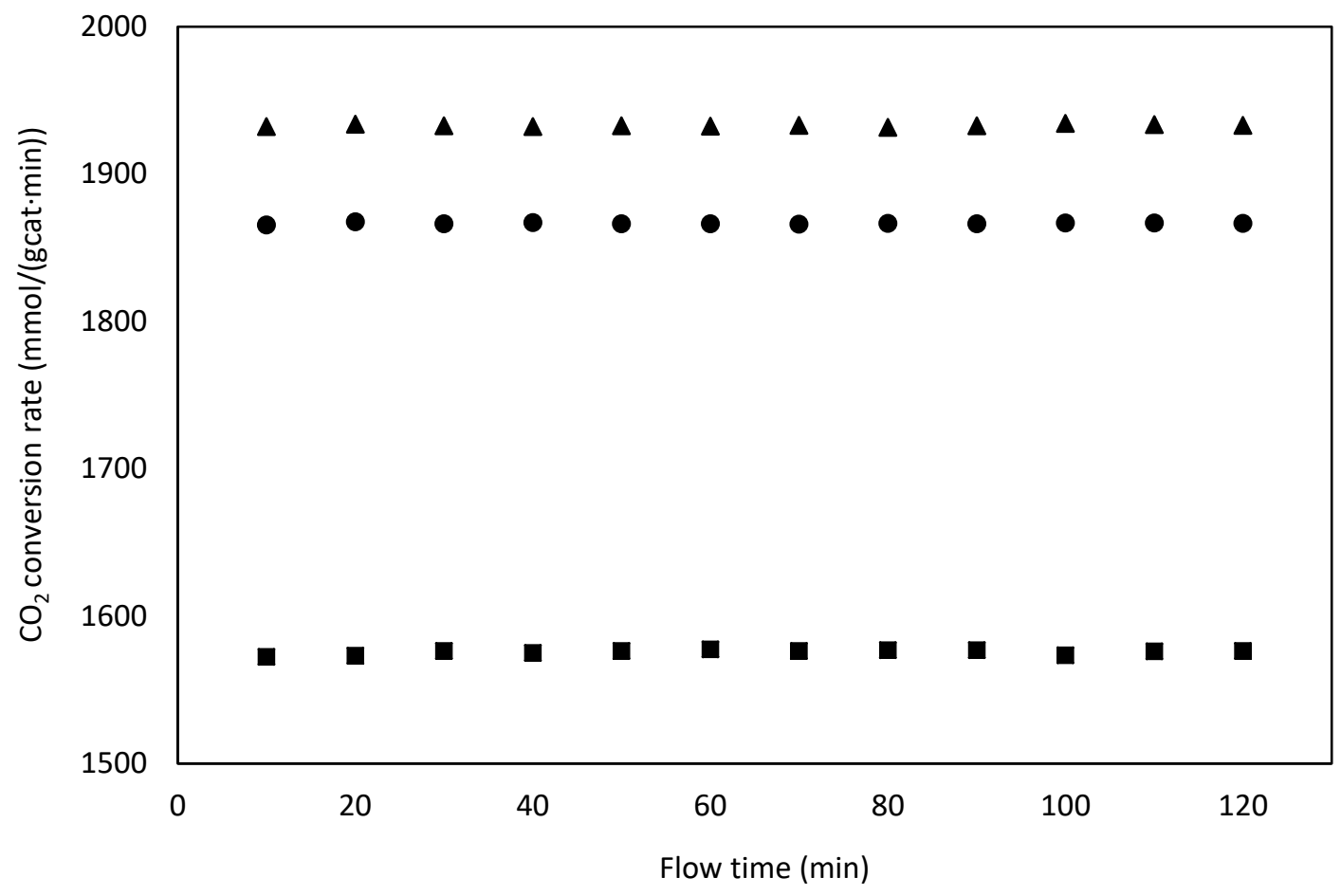

Figure 3.12. $\mathrm{CO}_{2}$ hydrogenation at high pressures ( 50 bar $\mathbf{\bullet}, 80$ bar $\bullet, 100$ bar $\boldsymbol{\Delta}$ ).

It is shown that $\mathrm{CO}_{2}$ conversion rates continued improving when the pressure was increased above the critical point. However, this improvement was limited when pressure continued raising in supercritical conditions, not generating a large benefit working at 100 bar compared with the results obtained at 80 bar. As a result, increasing pressure always represented a benefit for the reaction, although this increment was not too important after coming across the critical point.

\section{Conclusions}

A bimetallic catalyst has been synthetized using hydrazine to deposit copper nanoparticles onto zinc oxide nanorods. Hydrazine amount has been optimized in order to reduce all the copper avoiding damage in the $\mathrm{ZnO}$ nanorods.

The catalyst synthesized has been characterized to test its light absorption spectra. Copper has been proved to absorb higher amount of light at $580 \mathrm{~nm}$. $\mathrm{ZnO}$ nanorods 
maintain their peak absorption at $370 \mathrm{~nm}$. The bimetallic catalyst has been loaded in hydrophilic silica aerogels to allow their use in the carbon dioxide hydrogenation. The silica composite has also been characterized and impregnated in $0.5 \mathrm{~mm}$ ID glass microreactors with good adherence to the walls of the microchannels.

Carbon dioxide hydrogenation has been performed in an experimental plant to study the influence of the pressure in the reaction. Pressure has been shown to enhance the $\mathrm{CO}_{2}$ conversion rates, particularly working at supercritical conditions when the results were improved four-fold compared to the $\mathrm{CO}_{2}$ conversion rate obtained in Chapter II.

\section{References}

1. Le Quéré, C., et al., Global Carbon Budget 2017, Earth System Science Data, 2018, 10(1), 405-448.

2. Reid, P. C., et al., Impacts of the oceans on climate change. Advances in Marine Biology, 2010, 56.

3. Fernandez - Dacosta, C., Stojcheva, V., Ramirez, A., Closing carbon cycles: Evaluating the performance of multi-product $\mathrm{CO}_{2}$ utilisation and storage configurations in a refinery. Journal of $\mathrm{CO}_{2}$ Utilization, 2018, 23, $128-142$.

4. Albo, J., Preface (Editorial). Carbon Dioxide Capture: Processes, Technology and Environmental Implications, 2016, 277 - 300.

5. Centi, G., Quadrelli, E. A., Perathoner, S., Catalysis for $\mathrm{CO}_{2}$ conversion: A key technology for rapid introduction of renewable energy in the value chain of chemical industries. Energy \& Environmental Science, 2013, 6, 1711-1731.

6. Ganesh, I., Conversion of carbon dioxide into several potential chemical commodities following different pathways - A review. Materials Science Forum, 2013, 764, 1 - 82. 
7. Wang, W., et al., Recent advances in catalytic hydrogenation of carbon dioxide. Chemical Society Reviews, 2011, 40, 3703 - 3727.

8. Jadhav, S. G., et al., Catalytic carbon dioxide hydrogenation to methanol: A review of recent studies. Chemical Engineering Research and Design, 2014, 92(11), 2557 - 2567.

9. Koh, M. K., et al., Carbon dioxide hydrogenation to methanol over multi-functional catalyst: Effects of reactants adsorption and metal-oxide(s) interfacial area. Journal of Industrial and Engineering Chemistry, 2018, 62, 156 - 165.

10. Chan, G. H., et al., Plasmonic properties of copper nanoparticles fabricated by nanosphere lithography. Nano Letters, 2007, 7, 1947 -1952.

11. Tisseraud, $\mathrm{C}$., et al., The $\mathrm{Cu}-\mathrm{ZnO}$ synergy in methanol synthesis from $\mathrm{CO}_{2}$, Part 2: Origin of the methanol and $\mathrm{CO}$ selectivities explained by experimental studies and a sphere contact quantification model in randomly packed binary mixtures on $\mathrm{Cu}-\mathrm{ZnO}$ coprecipitate catalysts. Journal of Catalysis, 2015, 330, 533-544.

12. Tan, Z. Y., et al., Nanostructured $\mathrm{Cu} / \mathrm{ZnO}$ coupled composites: Toward tunable $\mathrm{Cu}$ nanoparticle sizes and plasmon absorption. The Journal of Physical Chemistry C, 2013, 117, 10780-10787.

13. Navarrete, et al., Novel windows for "solar commodities": A device for $\mathrm{CO}_{2}$ reduction using plasmonic catalyst activation. Faraday Discussions, 2015, 183, 249-259.

14. Nielsen, M. G., et al., A generic model for photocatalytic activity as a function of catalyst thickness. Journal of Catalysis, 2012, 289, 62 - 72.

15. Slosarczyk, A., Recent advances in research on the synthetic fiber based silica aerogel nanocomposites. Nanomaterials, 2017, 7(2), 44.

16. Das, S., Srivastava, V.C., Microfluidic-based photocatalytic microreactor for environmental application: A review of fabrication substrates and techniques, and operating parameters. Photochemical and Photobiological Sciences, 2016, 15, 714-730.

17. Zhang, Z., et al., Shape-controlled synthesis of zinc oxide: A simple method for the preparation of metal oxide nanocrystals in non-aqueous medium. Chemistry $-A$ European Journal, 2007, 13(2), 632-638. 
18. Sanz-Moral, L. M., et al., View cell investigation of silica aerogels during supercritical drying: Analysis of size variation and mass transfer mechanisms. The Journal of Supercritical Fluids, 2014, 92, 24-30.

19. Iswar, S., et al., Effect of aging on silica aerogel properties. Microporous and Mesoporous Materials, 2017, 241, 293 - 302.

20. Vanalakar S. A., et al., Controlled growth of $\mathrm{ZnO}$ nanorod arrays via wet chemical route for $\mathrm{NO}_{2}$ gas sensor applications. Sensors and Actuators, B: Chemical, 2015, 221, $1195-1201$.

21. Sanches, S. G., Flores, J. H., da Silva, M. I. P., Cu/ZnO and $\mathrm{Cu} / \mathrm{ZnO} / \mathrm{ZrO}_{2}$ catalysts used for methanol steam reforming. Molecular Catalysis, 2018, 454, 55-62.

22. Gaikwad, R., Bansode, A., Urakawa, A., High-pressure advantages in stoichiometric hydrogenation of carbon dioxide to methanol. Journal of Catalysis, 2016, 343, 127-132. 



\section{CONCLUSIONS}



This research is a contribution to fight against greenhouse effect and climate change generated by the increase of carbon dioxide emissions. The hydrogenation of carbon dioxide by means of light energy has been proposed as a solution to transform this gas avoiding sending it to the atmosphere.

The novel concept to perform this transformation has been explained in this thesis. The most important innovation was the design of a plasmonic microreactor device that integrated plasmon catalyst and reactor as one entity with a sole response to light. It has been the first time that the bimetallic catalyst $\mathrm{Cu} / \mathrm{ZnO}$ commonly used for the production of methanol has been integrated using surface plasmon resonance to perform the reaction in glass microreactors. Light transmission and composite activation were the fundamental aspects in the development of the thesis.

This work has been divided in three chapters where the development of this device and the optimization of the process have been carried out. The main conclusions obtained are summarized below:

- A catalyst that absorbs light in the visible and ultraviolet band has been synthetized. This catalyst consisted on discrete copper nanoparticles deposited onto zinc oxide nanorods. The light absorption of this material has been studied by UV-Vis spectrophotometry. However, it has been impossible to characterize the catalyst after the reaction, which would be important to understand the mechanism of the reaction and the role of the catalyst. The main problem was the low amount of catalyst used in each reaction that was not enough to use conventional characterization techniques. Other alternatives such as synchrotron or in situ Raman spectroscopy were proposed, although they were not technically viable to be used in this work. 
- The bimetallic catalyst synthetized has been loaded in mesoporous silica aerogels achieving a maximum of $13 \%$ load in mass. Silica aerogels were selected as a support due to their high transparency to light and their high surface that allow the load of high amounts of catalyst. The nanocomposite developed has been characterized using techniques such as Transmission Electron Microscopy, Fourier Transform Infrared Spectroscopy and BET surface area analysis.

- The impregnation of the catalyst inside glass microreactors with $0.5 \mathrm{~mm}$ of internal diameter has been achieved by taking advantage of the properties of the hydrogels. The impregnation technique allowed to distribute the catalyst homogeneously through the entire length of the microchannels $(15 \mathrm{~cm})$ and ensured their complete filling avoiding empty spaces or air bubbles. After the drying process, the aerogels showed great adherence to the walls of the microchannels. The use of microreactors allowed to increase the efficiency of the illumination process.

- An experimental setup has been designed and built up to perform the reaction. This experimental plant ensured a precise control of the inlet gases and allowed to work at different pressures and temperatures to study their influence on the conversion of carbon dioxide. The light was provided by LEDs that surrounded the microreactor in order to provide the light in the most homogeneous way and illuminate the entire reactor. The experimental setup allowed to work at pressures up to 100 bar, which represents an improvement compared with 20 bar that is the maximum pressure used by other authors that work in photocatalytic transformation of carbon dioxide. This research has been the first time that supercritical conditions for carbon dioxide were reached working with a microreactor for the continuous transformation of carbon dioxide using a plasmonic catalyst. 
- On the other hand, the microGC showed problems to measure the methanol production due to the sensitivity of the equipment. The global production of methanol was in concordance with the amount of carbon dioxide transformed, although methanol was not measured in a continuous way and appeared in pulses.

- The first proof of concept showed that carbon dioxide hydrogenation by means of light energy was performed with good results. It was the first time that a transparent structure was used to perform the photocatalytic transformation of carbon dioxide in a continuous microreactor. It demonstrated that the idea proposed was technically viable and opened the possibility to improve the results obtained.

- The optimization of the process has been done in two different directions:

- The influence of the reaction parameters was studied in order to enhance the carbon dioxide conversion rates. Changes in temperature and gases flow did not affect $\mathrm{CO}_{2}$ conversion rates, not being useful to improve the process. However, the improvement in the efficiency of the developed process allowed to work at temperatures of $50{ }^{\circ} \mathrm{C}$, which represented a benefit compared with higher temperatures used at conventional methanol production.

An increase in the amount of catalyst was negative for the goal of improving the $\mathrm{CO}_{2}$ conversion rate, achieving better results for the smallest amount of catalyst. The key parameter to enhance the results was proved to be the pressure. Increasing pressure up to 50 bar improved $\mathrm{CO}_{2}$ conversion rate considerably, even though overpassing the critical point multiplied the benefit for the $\mathrm{CO}_{2}$ conversion rate. While other parameters provided a slight improvement, pressure improved up to $30 \%$ the $\mathrm{CO}_{2}$ conversion rate obtained. 
- A new method to reduce copper nanoparticles and deposit them onto zinc oxide nanorods has been developed. Hydrazine was selected as the reducing agent, controlling the amount added in order to reduce completely copper and avoiding damaging zinc oxide nanorods. The new catalyst synthetized was characterized by UV-Vis spectrophotometry and it showed an improvement in the light absorbed by copper nanoparticles around $580 \mathrm{~nm}$. The bimetallic catalyst was again loaded in mesoporous silica aerogels and impregnated in glass microreactors to perform the carbon dioxide hydrogenation. Pressure continued enhancing the $\mathrm{CO} 2$ conversion rates, particularly working at supercritical conditions. 


\section{RESUMEN}



La temperatura global del planeta ha ido aumentando en los últimos años debido a un fenómeno conocido como cambio climático. Una de las principales causas del cambio climático proviene de los gases de efecto invernadero que son capaces de atrapar el calor en la atmósfera. Cuando la luz solar alcanza la tierra y los océanos calentándolos, su superficie irradia energía térmica en el infrarrojo. Este calor no sale directamente del planeta, sino que es absorbido por los gases de efecto invernadero en la atmósfera y liberado gradualmente a lo largo del tiempo. El efecto invernadero es necesario para la vida en el planeta, manteniendo las condiciones de temperatura evitando la congelación. Sin embargo, el enorme aumento de la concentración de estos gases en la atmósfera ha roto el equilibrio natural de la temperatura en el planeta manteniendo más calor de lo necesario. Como resultado, la temperatura global ha crecido en los últimos años y la tendencia es continuar aumentando en los próximos años.

Entre los gases de efecto invernadero, el principal responsable del cambio climático es el dióxido de carbono. Desde la revolución industrial las emisiones de este gas han crecido año tras año, debido fundamentalmente a la quema de combustibles fósiles para la obtención de energía. Antes de la revolución industrial la concentración de dióxido de carbono era de 277 ppm, alcanzándose las 402 ppm hoy en día. La naturaleza no es capaz de mitigar este aumento de la concentración y el aumento de la temperatura del planeta que conlleva, por lo que hay que buscar soluciones para revertir esta tendencia.

El acuerdo conocido como COP21 alcanzado en París supone un gran avance en la lucha contra el cambio climático y va a ayudar a reducir las emisiones de dióxido de carbono. Sin embargo, es imposible eliminar las emisiones completamente ya que los combustibles fósiles van a continuar siendo la principal fuente de energía en los próximos años. Es por ello que se están desarrollando nuevas tecnologías que puedan ayudar a que ese dióxido 
de carbono producido no llegue a la atmósfera. Para ello se han propuesto dos posibilidades: la captura y el almacenamiento o su uso en diferentes procesos industriales (Figura 1). Dentro de los procesos en los que el dióxido de carbono puede ser utilizado, destaca su transformación en otras sustancias químicas o en combustibles porque le dan un valor añadido al proceso, ayudando así a que la transformación pueda ser económicamente viable.

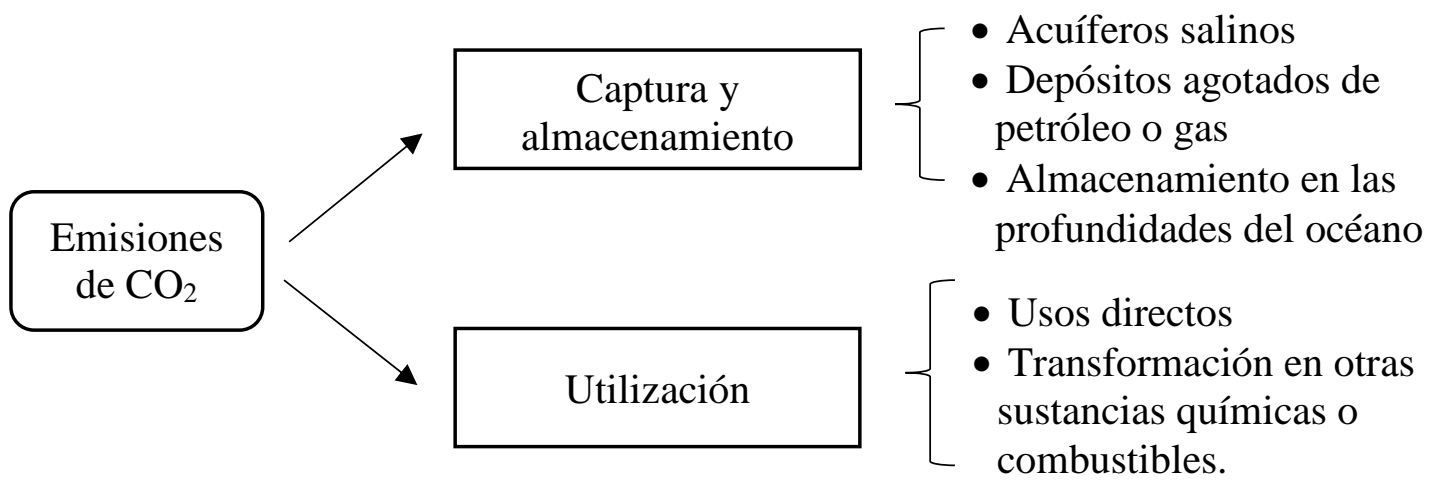

Figura 1. Posibilidades para reducir las emisiones de dióxido de carbono a la atmósfera.

Entre las diferentes posibilidades en las que el dióxido de carbono puede ser transformado, su conversión para dar lugar a combustibles ha atraído mucha atención en los últimos años. Los combustibles fósiles van a seguir siendo la principal fuente de energía en los próximos años, pero las reservas son limitadas y acabarán por agotarse.

Diferentes vías para la producción de combustibles a partir del dióxido de carbono han comenzado a ser estudiadas, como el uso de microalgas o la reducción electroquímica. Sin embargo, el método más común continúa siendo la hidrogenación del dióxido de carbono. Dependiendo del catalizador usado y las condiciones de presión y temperatura los productos obtenidos pueden variar (Figura 2). 


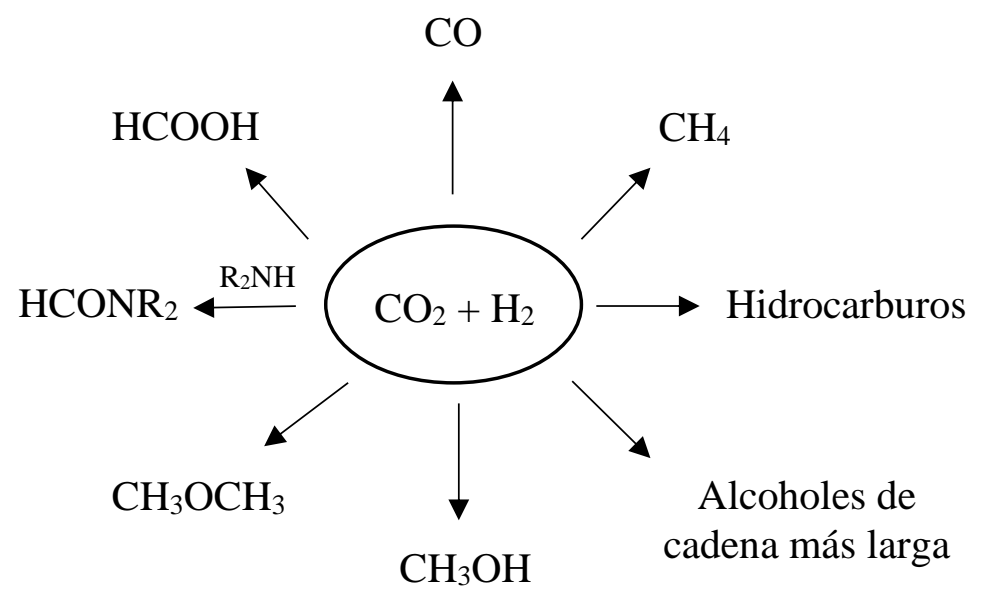

Figura 2. Diferentes productos obtenidos en la hidrogenación del $\mathrm{CO}_{2}$ (Wang et al., Chemical Society Reviews, 2011).

Entre estos productos se encuentra el metanol que puede ser usado como combustible. Para su producción destaca el uso de catalizadores basados en cobre, especialmente la combinación con óxido de zinc debido a la sinergia que se produce y que permite una gran selectividad hacia la producción de metanol. Una vez que estos catalizadores están muy estudiados y su aplicación en la industria es común, el objetivo pendiente sigue siendo poder realizar la reacción usando energías renovables para evitar producir más $\mathrm{CO}_{2}$ al quemar combustibles fósiles para obtener la energía necesaria para la reacción.

Entre las energías renovables, muchos estudios sugieren que la energía solar puede ser la mejor opción para realizar la reacción. El mayor problema en los procesos fotocatalíticos se debe a sus bajas eficiencias derivadas del insuficiente uso que se hace de la luz solar. Por ello, actualmente se trabaja en el diseño de nuevos catalizadores que amplíen el espectro de la luz utilizado absorbiendo así mayor energía y mejorando la eficiencia del proceso. La resonancia superficial de plasmones es un fenómeno que permite ampliar la energía absorbida de la luz por parte de las nanopartículas de algunos metales, entre los 
que se encuentran la plata y el oro como los más estudiados. Sin embargo, el cobre también muestra este efecto, y dado que es un catalizador comúnmente empleado en la hidrogenación del dióxido de carbono, la resonancia de plasmones puede ser utilizada para activar también este catalizador y aumentar la eficiencia de la transformación fotocatalítica del dióxido de carbono.

\section{Objetivos}

Muchos procesos han sido propuestos para realizar la transformación del dióxido de carbono y dar lugar a diferentes productos ayudando así a reducir las emisiones de dióxido de carbono a la atmósfera y mitigar el efecto del cambio climático. De entre todos estos procesos, la transformación en combustibles aporta un valor añadido al proceso, abriendo la posibilidad de producir está transformación de forma viable desde el punto de vista económico. La hidrogenación del dióxido de carbono produce metanol, el cuál es considerado como un combustible con una alta demanda a nivel mundial.

En este trabajo de investigación la luz es propuesta como única fuente de energía para llevar a cabo la reacción evitando así el uso de combustibles fósiles que producirían más dióxido de carbono al ser quemados para obtener energía. En el campo de la fotocatálisis se han estudiado diferentes catalizadores, aunque las eficiencias obtenidas continúan siendo bajas. Algunas tecnologías se han enfocado en mejorar la absorción de luz por parte del catalizador, y la resonancia superficial de plasmones ha demostrado que puede ser una alternativa útil para incrementar la energía absorbida por el catalizador en la franja del visible. 
El objetivo general de este trabajo es realizar la hidrogenación del dióxido de carbono activada mediante luz. Para lograr este objetivo general es necesario desarrollar varios objetivos más específicos:

- Síntesis de catalizadores y soportes que sean capaces de aumentar la conversión del dióxido de carbono mediante energía lumínica. Este objetivo conlleva el desarrollo de un sistema catalítico compuesto de nanopartículas metálicas capaces de exhibir el efecto de resonancia superficial de plasmones, y de un soporte transparente con gran área superficial que permita a la luz llegar hasta las nanopartículas en su interior y activar al catalizador.

- Diseño y montaje de una planta experimental para poder realizar la reacción química, permitiendo un control muy preciso de los parámetros de operación (desde los caudales de entrada de los gases a la presión y la temperatura), y un método para analizar los gases de salida directamente en línea. Se pondrá un especial énfasis en la parte del diseño del reactor, desarrollando un procedimiento para impregnar microreactores de vidrio homogéneamente con el catalizador sintetizado previamente, además de construir un sistema para integrar un conjunto de luces LED que sea capaz de iluminar el reactor completamente, aportando la luz de la forma más homogénea posible.

- Realización de una prueba de concepto con el objetivo de demostrar que la idea propuesta es viable desde el punto de vista técnico y que la hidrogenación del dióxido de carbono activada mediante luz puede ser llevada a cabo con buenos resultados. Tras ello, se trabajará en la optimización del proceso investigando en dos direcciones: mejorar la absorción de la luz del catalizador sintetizado y estudiar la influencia de las variables de reacción en la transformación del dióxido de carbono. 


\section{Resultados y discusión}

Esta tesis doctoral se ha dividido en 3 capítulos diferenciados. En el Capítulo I, titulado "A device for $\mathrm{CO}_{2}$ reduction using plasmonic catalyst activation", se introdujo el novedoso concepto en el que se fundamentó la investigación. El objetivo fue llevar a cabo una primera prueba de concepto en la que se demostrara que la idea era técnicamente viable.

La transformación del dióxido de carbono en metanol fue propuesta como solución a dos problemas simultáneamente: contribuir a reducir las emisiones de este gas contaminante a la atmósfera, y a la vez poder guardar la energía del sol en forma de combustible (metanol) para poder ser usada cuando se necesite y evitar la intermitencia que suele estar asociada a las energías renovables.

La producción de metanol a partir del $\mathrm{CO}_{2}$ involucra a las siguientes reacciones:

$$
\begin{aligned}
& \mathrm{CO}_{2}+\mathrm{H}_{2} \Leftrightarrow \mathrm{CO}+\mathrm{H}_{2} \mathrm{O} ; \Delta \mathrm{H}^{0}=+41.19 \mathrm{~kJ} / \mathrm{mol} \\
& \mathrm{CO}+2 \mathrm{H}_{2} \Leftrightarrow \mathrm{CH}_{3} \mathrm{OH} ; \Delta H^{0}=-90.70 \mathrm{~kJ} / \mathrm{mol} \\
& \mathrm{CO}_{2}+3 \mathrm{H}_{2} \Leftrightarrow \mathrm{CH}_{3} \mathrm{OH}+\mathrm{H}_{2} \mathrm{O} ; \Delta \mathrm{H}^{0}=-49.51 \mathrm{~kJ} / \mathrm{mol}
\end{aligned}
$$

La eficiencia de las reacciones químicas no depende únicamente del catalizador empleado, sino que hay una gran influencia de la configuración del reactor empleada y de la transferencia de masa y energía que se produce. Es por ello que muchas veces estructuras catalíticas muy prometedoras fracasan en su aplicación debido a que no son integradas debidamente con el reactor. 
En este trabajo se propuso utilizar un microreactor plasmónico en el que el reactor y el catalizador quedaran integrados como una sola unidad con una respuesta común a la luz. Para lograr este objetivo fueron necesarios varios pasos en los que hubo que decidir el método de síntesis para producir el catalizador basado en cobre activado mediante luz, el mejor soporte para el catalizador que garantizara que la luz llegue al catalizador para activarlo, y el reactor idóneo para que la reacción se produzca.

En primer lugar, un catalizador bimetálico $\mathrm{Cu} / \mathrm{ZnO}$ fue sintetizado siguiendo el método propuesto por Tan et al. (2013). Este método permitió sintetizar nanopartículas de cobre de tamaño controlado, y depositarlas sobre la superficie de nanorods de óxido de zinc. La absorción de luz por el catalizador fue estudiada mediante espectrofotometría ultravioleta - visible (Figura 3).
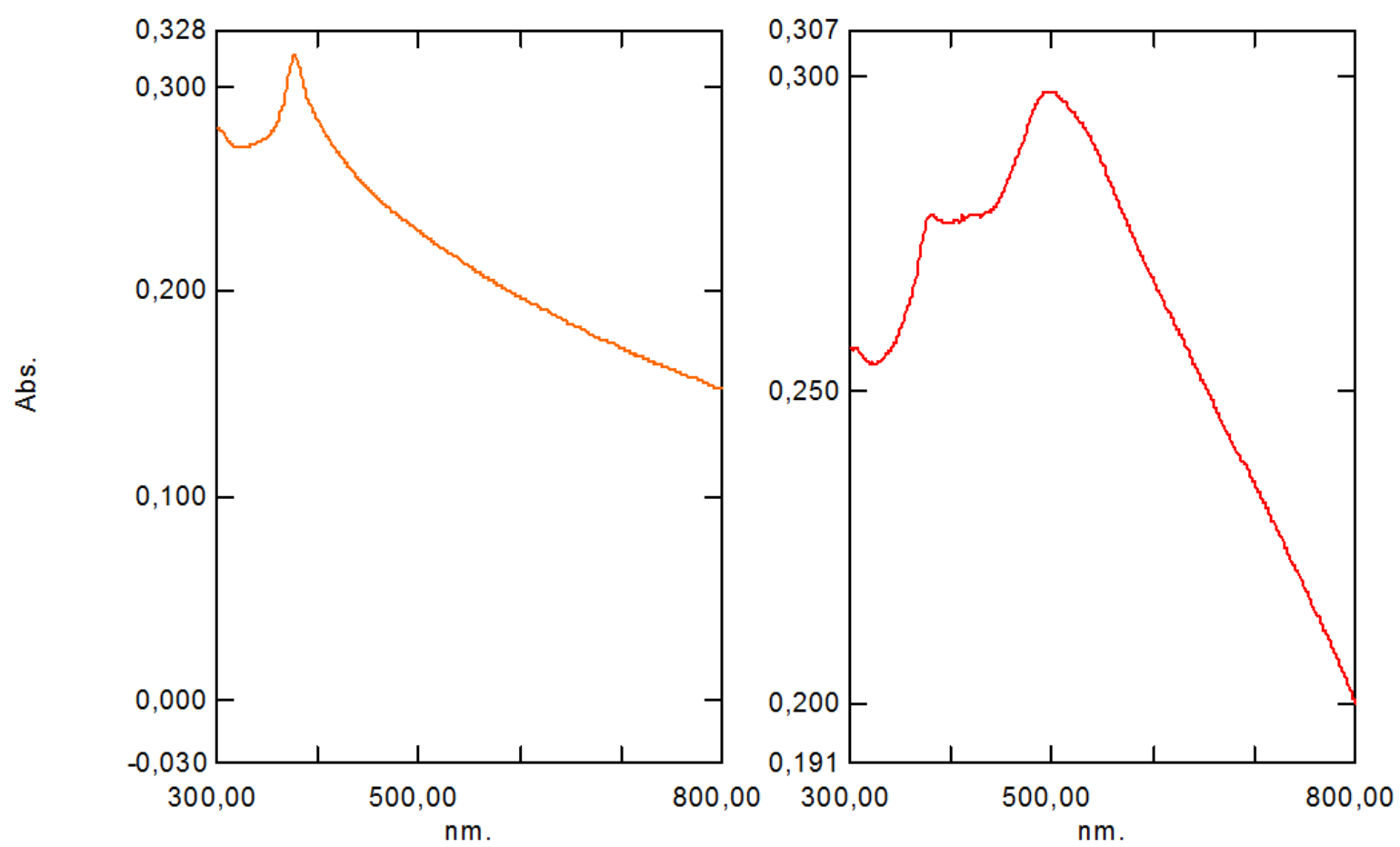

Figura 3. Espectro UV-Vis del catalizador $\mathrm{Cu} / \mathrm{ZnO}$. 
Se observó que el catalizador bimetálico mostró un pico a $370 \mathrm{~nm}$ que corresponde al óxido de zinc, y otro pico alrededor de los $500 \mathrm{~nm}$ debido a las nanopartículas de cobre y que se corresponde a la absorción en un color próximo al verde.

El siguiente paso fue la elección de un soporte para las nanopartículas metálicas que permitiera a la luz llegar hasta el catalizador, además de garantizar que se pudiera cargar una gran cantidad de catalizador en su interior. Con este fin se seleccionaron los aerogeles de sílice, ya que son materiales mesoporosos transparentes a la luz y que poseen grandes áreas superficiales. Los aerogeles fueron sintetizados siguiendo el método propuesto por Sanz-Moral et al. (2014). En este método se siguió la ruta del sol-gel en la que el precursor de sílice empleado fue el tetrametil ortosilicato (TMOS). Se utilizó una relación molar TMOS: $\mathrm{CH}_{3} \mathrm{OH}: \mathrm{H}_{2} \mathrm{O}: \mathrm{NH}_{4}$, de $1: 2.3: 3.84: 0.012$. El catalizador fue previamente dispersado en el metanol con ayuda de ultrasonidos, y después mezclado con el resto de reactivos para dar lugar al aerogel con el catalizador en su interior (Figura 4).
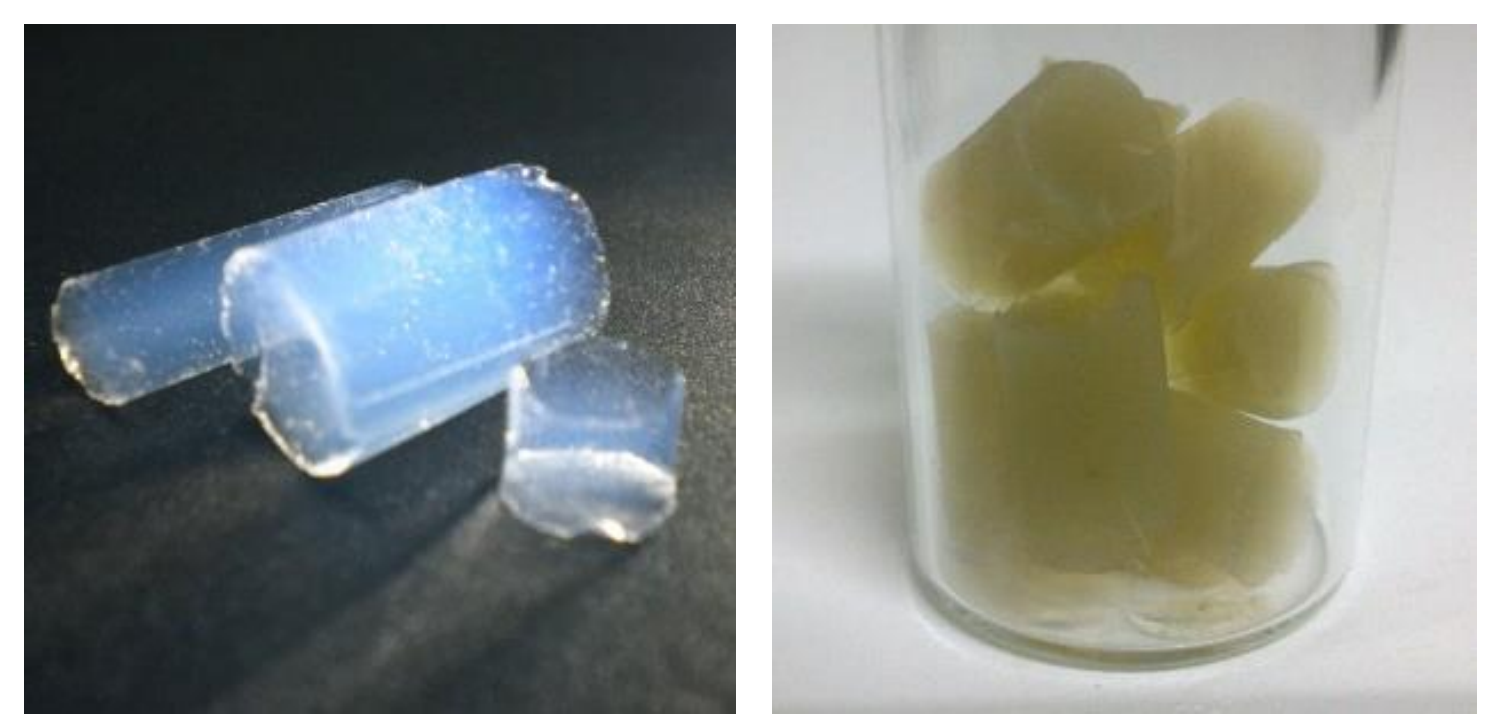

Figura 4. Aerogeles de sílice (izquierda) y aerogeles cargados con el catalizador (derecha). 
Para llevar a cabo la reacción, se decidió que la mejor opción eran microreactores de vidrio que presentaban diferentes ventajas para ser aplicadas en este trabajo. Al estar hechos de vidrio permitieron su aplicación en reacciones fotocatalíticas, y al ser microreactores mejoraron la eficiencia de la transferencia de energía y de masa, además de ser fácilmente escalables, permitir trabajar en continuo y aportar beneficios para la seguridad al usar cantidades pequeñas de reactivos.

La impregnación del soporte con las nanopartículas en los microreactores fue realizada aprovechando las propiedades de los aerogeles. En su síntesis, la primera etapa da lugar a un hidrogel que permanece en forma líquida durante un tiempo breve que puede ser ajustada con la cantidad de amonio empleada. Este tiempo fue aprovechado para utilizar una jeringa con la que llenar el microreactor con el hidrogel líquido (Figura 5), y que tras unos segundos comenzó a gelificar en el interior del microreactor adhiriéndose a las paredes del microcanal.

Tras ser impregnados en el interior del reactor, los aerogeles fueron envejecidos durante 24 horas calentado a $50{ }^{\circ} \mathrm{C}$ en un recipiente con metanol para eliminar el agua de su estructura. El último paso fue el secado con $\mathrm{CO}_{2}$ supercrítico para dar lugar a los aerogeles. Para ello, los microreactores fueron colocados en un recipiente de alta presión lleno de metanol, y se introdujo $\mathrm{CO}_{2}$ a 100 bar y $40{ }^{\circ} \mathrm{C}$, por encima del punto crítico. Se realizaron 3 ciclos de 45 minutos, renovando el $\mathrm{CO}_{2}$ entre ciclo y ciclo para eliminar completamente el metanol. 


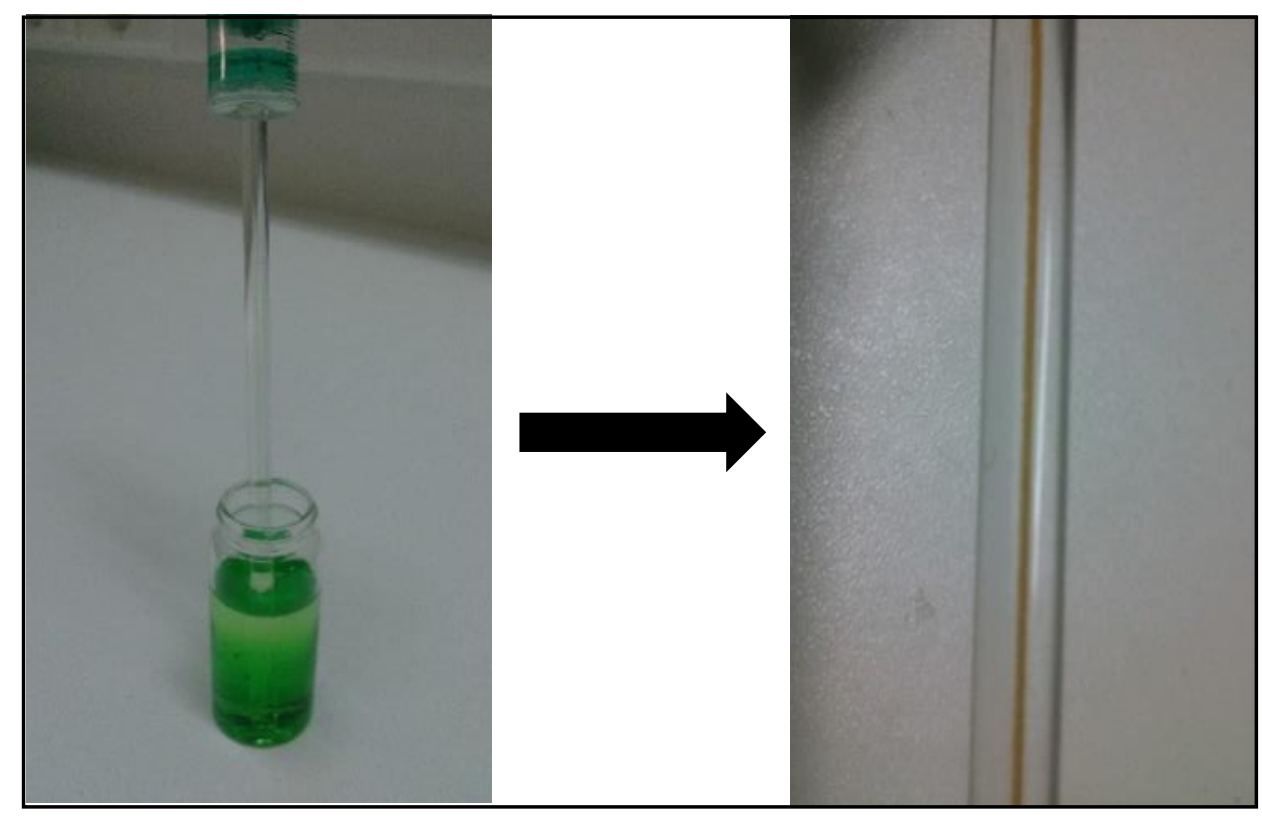

Figura 5. Impregnación del catalizador en los microreactores.

Una vez que el catalizador y el reactor estaban listos, se diseñó y construyó la planta experimental para llevar a cabo la reacción de hidrogenación del dióxido de carbono (Figura 6).

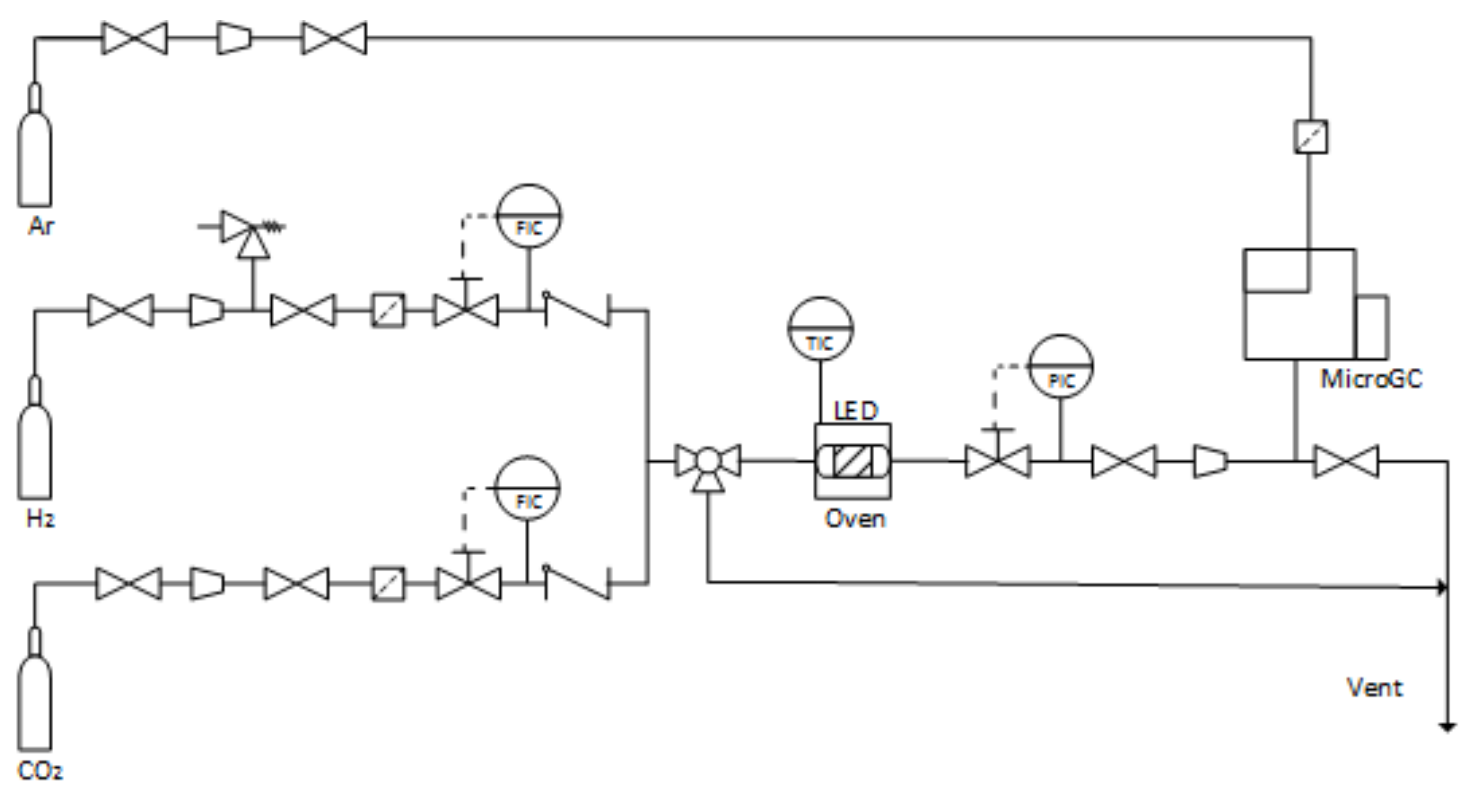

Figura 6. Esquema de la planta experimental para la hidrogenación del dióxido de carbono. 
En esta planta experimental, el hidrógeno y el dióxido de carbono fueron mezclados en una proporción 3:1 en volumen y calentados en un horno antes de llegar al microreactor, que consistió en un capilar de vidrio de medio milímetro de diámetro interno y $5 \mathrm{~mm}$ de diámetro externo. A la salida del microreactor se colocó un controlador de presión para trabajar a 20 bar. La luz fue aportada por un sistema de 36 LEDs que fueron colocadas rodeando al microreactor como se muestra en la Figura 7, con una potencia de $9780 \mathrm{~W} / \mathrm{m}^{2}$ de luz blanca.
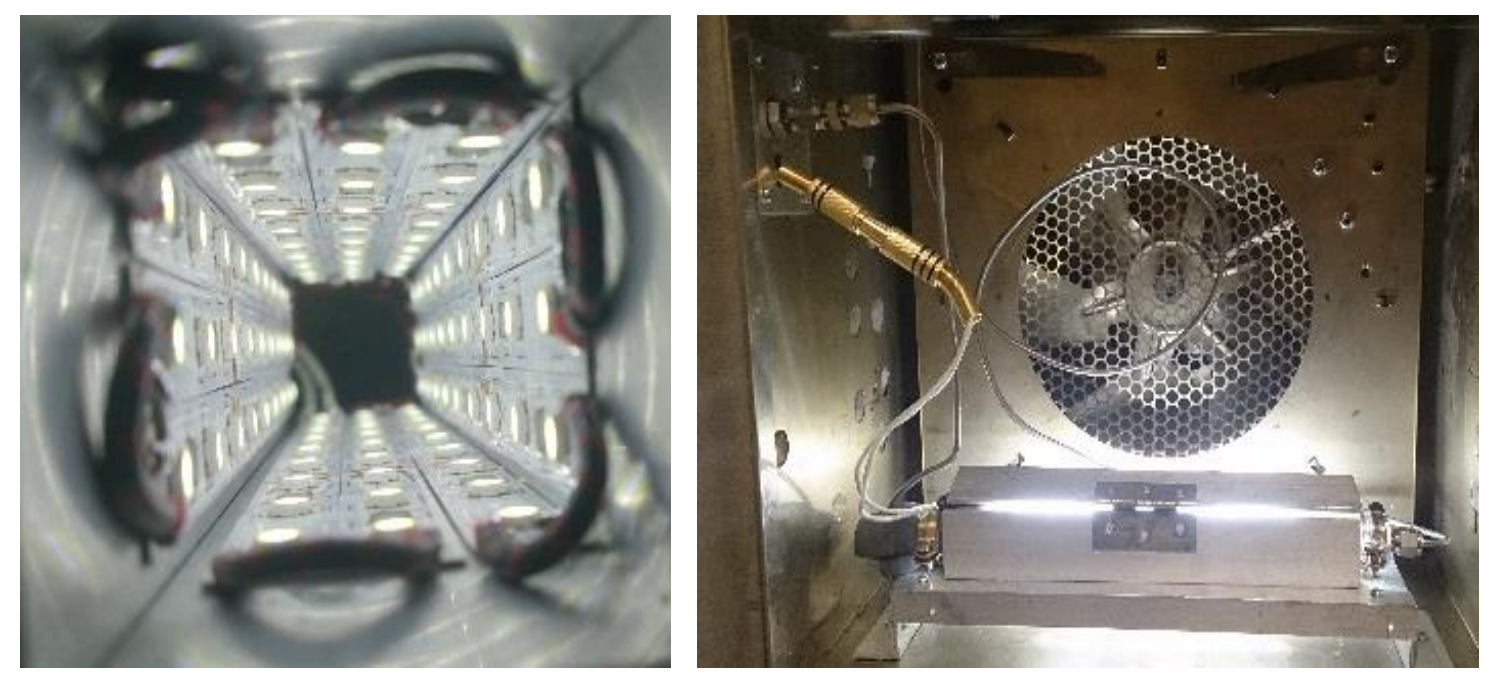

Figura 7. Configuración de las luces LED. Vista del interior del dispositivo donde se integraron las 36 LED (izquierda). Microreactor colocado en el interior del horno rodeado del dispositivo de LED (derecha).

Para llevar a cabo la reacción, se conectaron las luces LED y se hicieron pruebas cambiando el flujo de gas y la temperatura de operación, trabajando siempre a 20 bar. Se pudo observar que los resultados fueron estables a $50{ }^{\circ} \mathrm{C}$ durante más de 100 minutos. Después se aumentó la temperatura hasta $70{ }^{\circ} \mathrm{C}$ durante el mismo periodo de tiempo. Finalmente, el flujo de gas se redujo a la mitad de las condiciones iniciales. En total, durante los 300 minutos de reacción no se observaron cambios importantes en la velocidad de conversión de $\mathrm{CO}_{2}$, manteniéndose estable alrededor de los 381,05 
$\mathrm{mmol} / \mathrm{g}_{\mathrm{cat}} \cdot \mathrm{min}$. Estos resultados obtenidos fueron similares a otros trabajos que usaron catalizadores plasmónicos pero trabajando a mayores temperaturas. Esto se pudo deber a la mejora en la transmisión de la luz hasta el catalizador y la síntesis de un material mejor integrado con el reactor para producir la reacción.

En el Capítulo II, titulado "Study of the influence of the reaction variables", se realizó un completo estudio de la influencia de las diferentes variables que intervienen en la reacción con el objetivo de maximizar la velocidad de conversión del $\mathrm{CO}_{2}$. Como variables a analizar se seleccionaron la temperatura, la carga de catalizador, la proporción de mezcla de los reactivos y la presión.

Antes de realizar este estudio, se completó la caracterización del catalizador por medio de la Microscopía de Trasmisión Electrónica para comprobar que las nanopartículas de cobre se encontraban correctamente depositadas sobre la superficie de los nanorods de óxido de zinc (Figura 8).
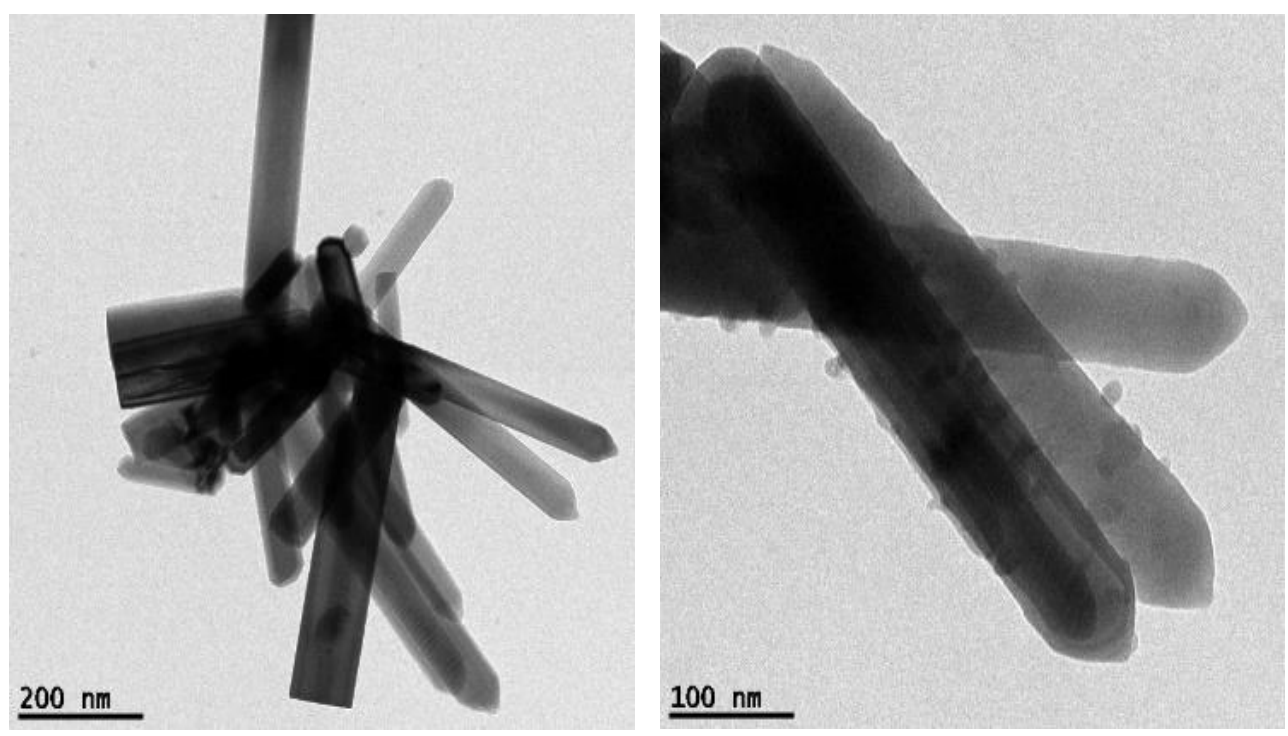

Figura 8. Imágenes TEM de los nanorods de $\mathrm{ZnO}$ (izquierda) y de las nanopartículas de cobre depositadas en la superficie de los nanorods (derecha). 
Se observó que los nanorods de óxido de zinc se encontraban correctamente formados y que las nanopartículas de cobre se habían depositado evitando aglomeraciones como era el objetivo. Además, utilizando la misma técnica se analizó la impregnación del catalizador bimetálico en la estructura de sílice del aerogel para asegurar que se había cargado correctamente (Figura 9).
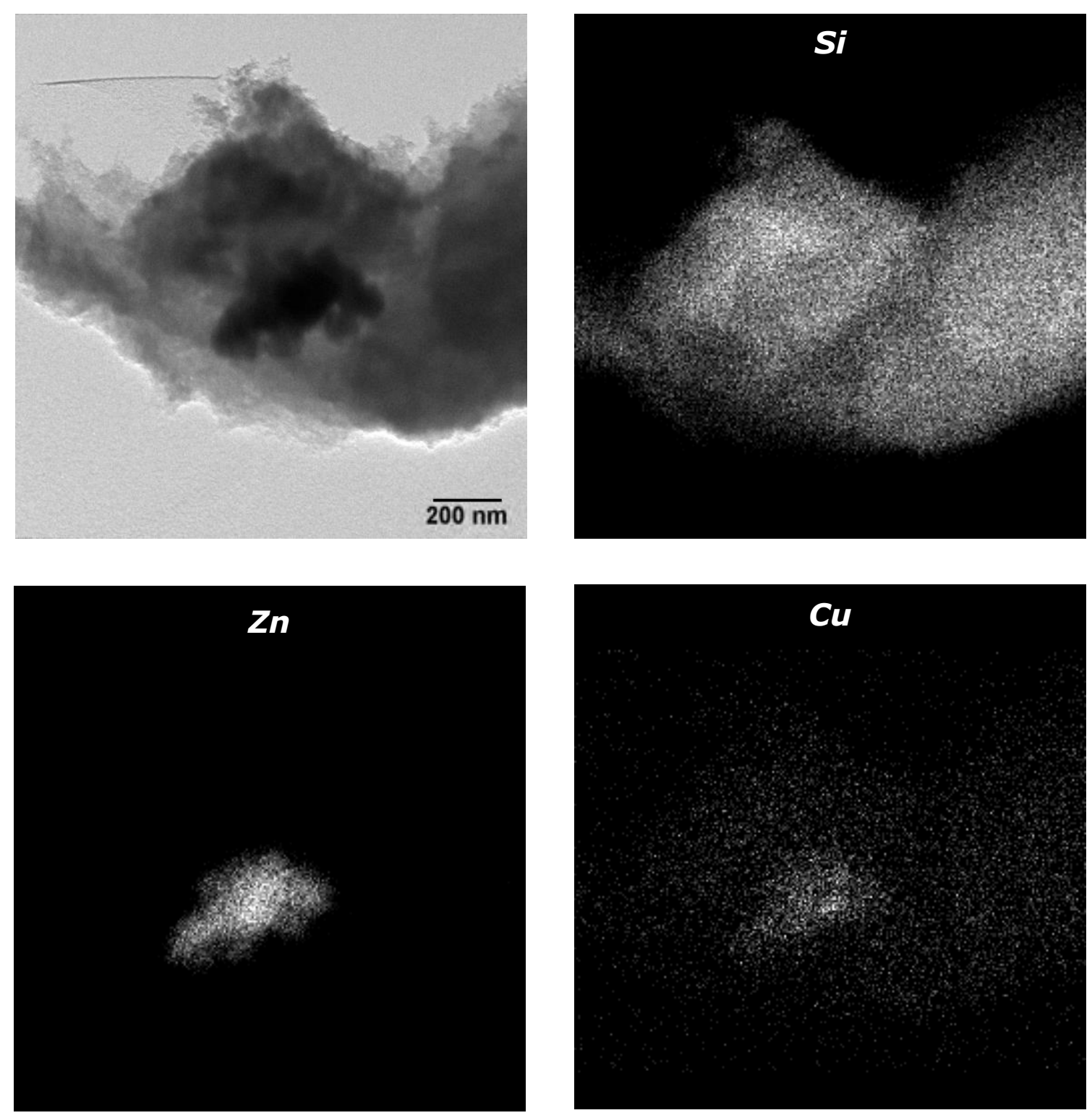

Figura 9. Imágenes TEM del aerogel de sílice con el catalizador en su interior y distribución de la sílice, el zinc y el cobre usando la técnica de campo oscuro. 
Usando la técnica de campo oscuro se identificó a la sílice como el componente mayoritario presente a lo largo de toda la estructura, mientras que los nanorods de óxido de zinc se encontraron juntos en la misma zona del aerogel. En cuanto al cobre, gran parte se identificó en la misma zona que el óxido de zinc lo cual indica que continúan depositadas en su superficie. Sin embargo, una importante cantidad de partículas fue hallada lejos de los nanorods por lo que no fueron correctamente depositadas.

Tras completar la caracterización del material sintetizado, se comenzó a estudiar la influencia de las distintas variables en la reacción. En primer lugar, para analizar la influencia de la temperatura se realizaron experimentos trabajando siempre a 20 bar, carga de catalizador del $10 \%$ en peso en el aerogel, y flujos de 1 y $0,33 \mathrm{ml} / \mathrm{min}$ de $\mathrm{H}_{2}$ y $\mathrm{CO}_{2}$ respectivamente (Figura 10).

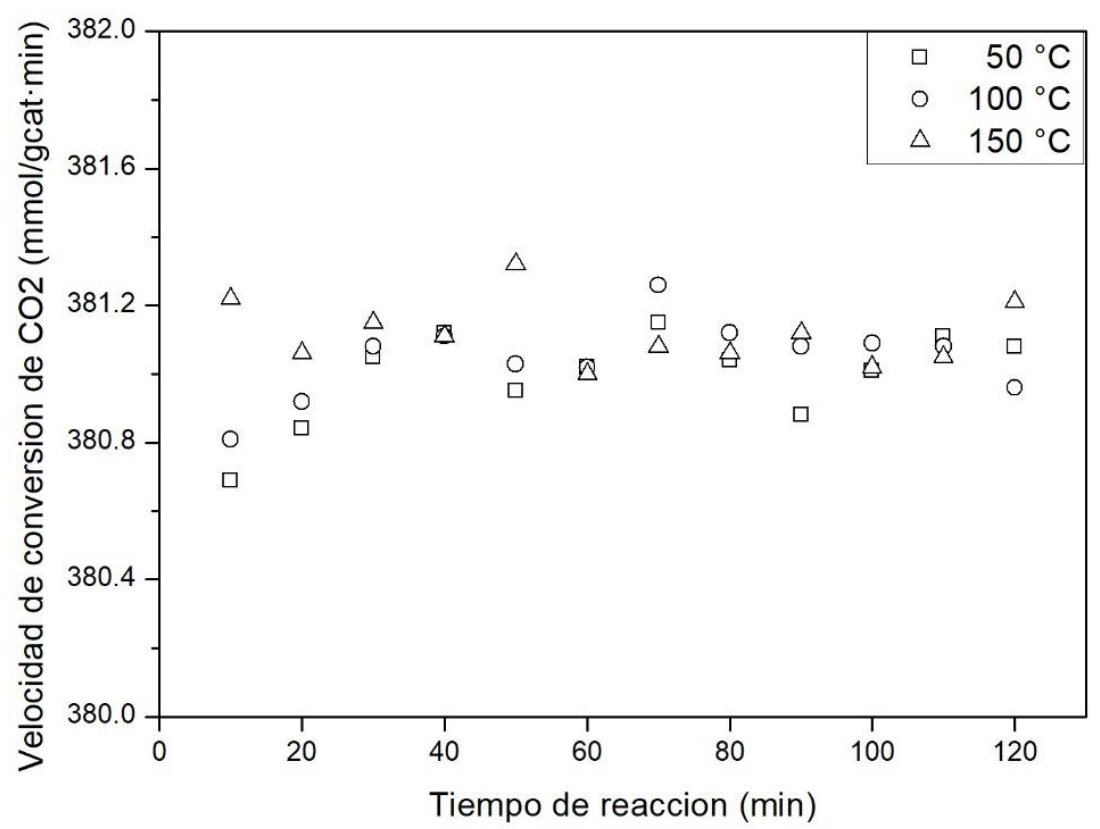

Figura 10. Influencia de la temperatura de precalentamiento en la reacción.

$\mathrm{Al}$ no haber cambios en la conversión del $\mathrm{CO}_{2}$ obtenida, se decidió trabajar siempre a 50 ${ }^{\circ} \mathrm{C}$ en los siguientes experimentos. Para estudiar la influencia de la carga de catalizador, 
se hicieron pruebas para 7, 10 y $13 \%$ de catalizador cargado en el aerogel en peso, manteniendo el resto de condiciones igual que en el caso anterior (Figura 11).

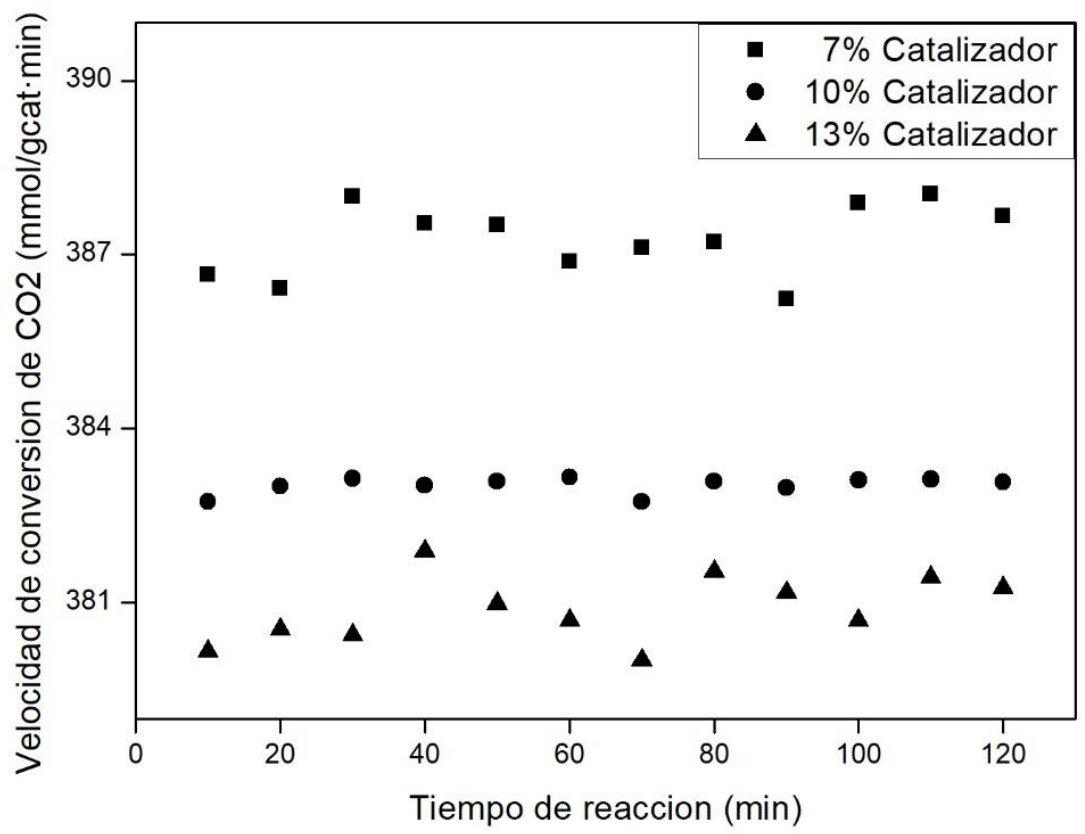

Figura 11. Influencia de la cantidad de catalizador en la reacción.

Con estos resultados se mostró que aumentar la cantidad de catalizador en el aerogel no sirvió para mejorar la velocidad de conversión del $\mathrm{CO}_{2}$, sino que por el contrario los mejores resultados se obtuvieron para la menor cantidad de catalizador utilizada. En cuanto a la proporción en que los gases de entrada fueron mezclados, se realizaron experimentos a 20 bar, $50{ }^{\circ} \mathrm{C}$ y $10 \%$ de carga de catalizador para analizar su influencia (Figura 12). 


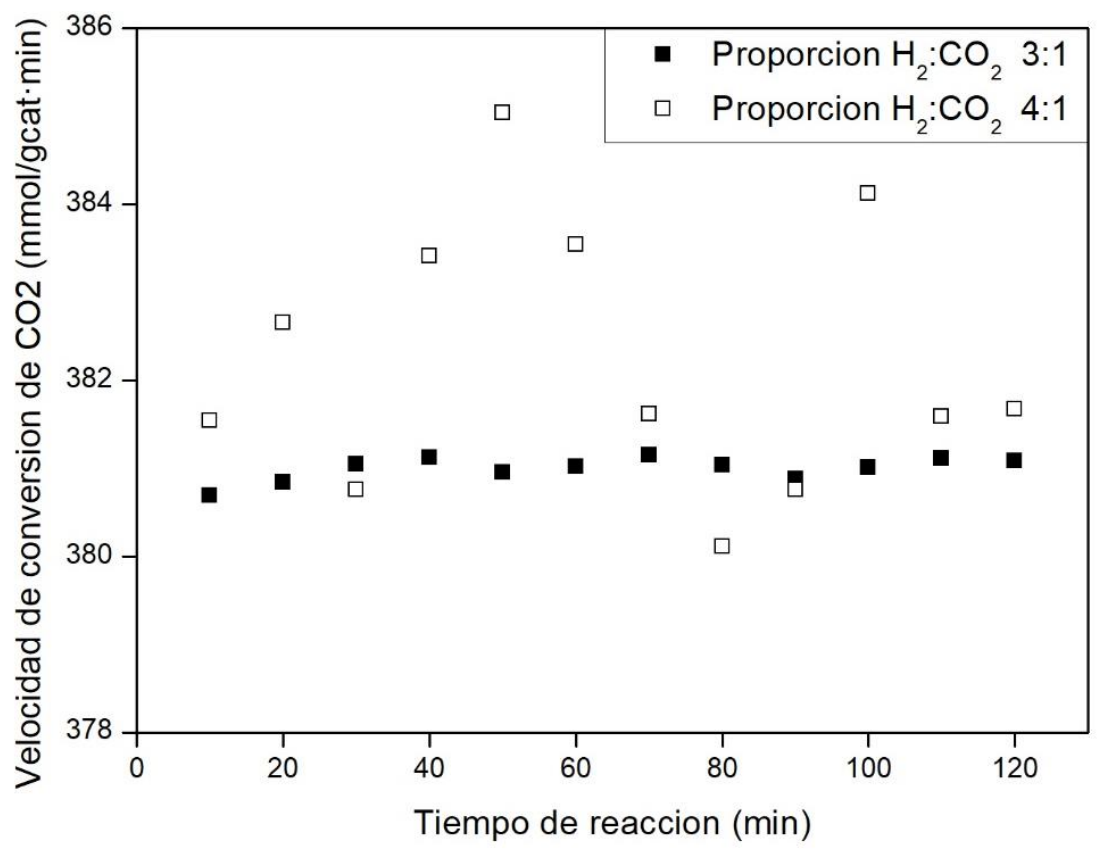

Figura 12. Influencia de la proporción $\mathrm{H}_{2}: \mathrm{CO}_{2}$ en la reacción.

En esta gráfica se pudo observar que un aumento en la proporción de hidrógeno no supuso una mejora apreciable, por lo que se descartó trabajar con mayor cantidad de $\mathrm{H}_{2}$ debido al mayor gasto que supone sin mejorar los resultados. Finalmente, la presión fue la última variable analizada (Figura 13).

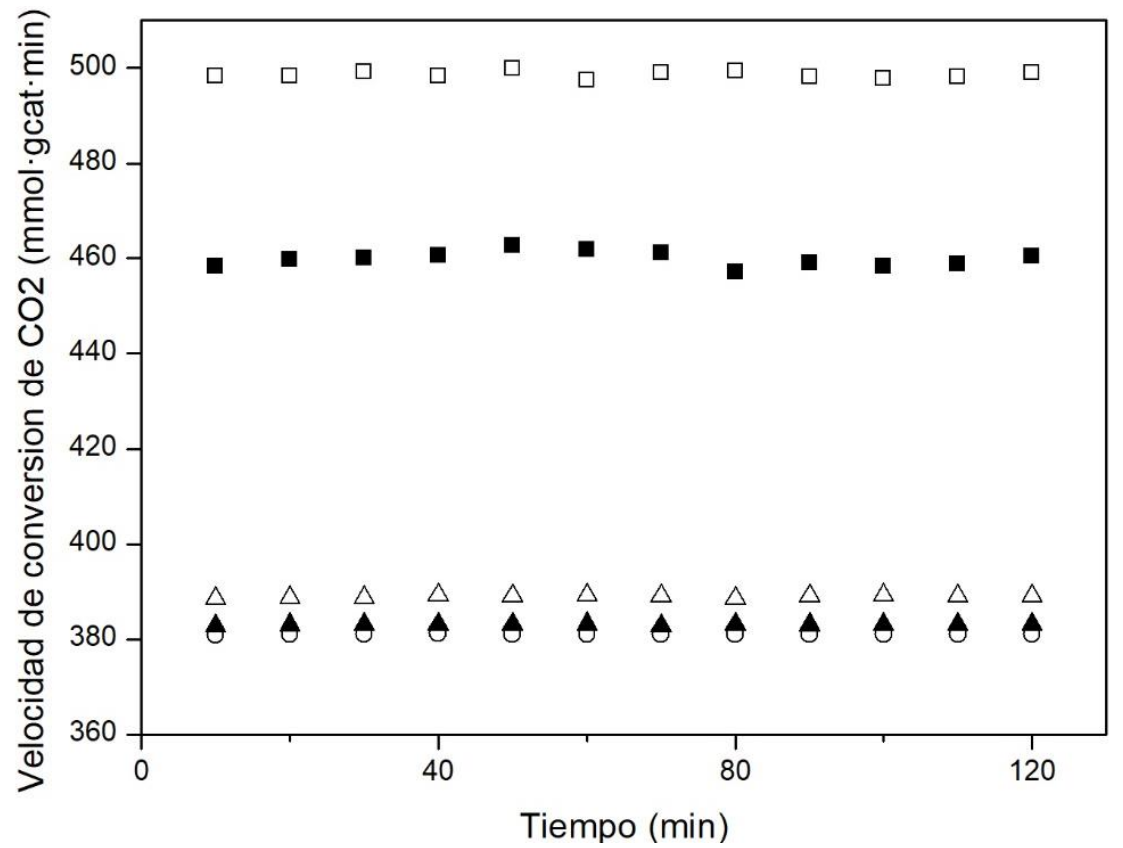

Figura 13. Influencia de la presión en la reacción ( 20 bar $\circ, 30$ bar $\mathbf{\Lambda}, 50$ bar $\Delta, 80$ bar $\mathbf{\square}, 100$ bar $\square$ ). 
De estos resultados se pudo concluir que aumentar la presión conllevó una gran mejora de las velocidades de conversión del $\mathrm{CO}_{2}$ obtenidas. Esta mejora fue en aumento cuanto mayor fue la presión de trabajo, especialmente tras pasar el punto crítico del $\mathrm{CO}_{2}$. Para la mayor presión de trabajo, 100 bar, los resultados obtenidos mejoraron en un $31 \%$ respecto a los resultados iniciales. Por lo tanto, la conclusión de este estudio ha sido que la presión es el parámetro clave para maximizar la velocidad de conversión del dióxido de carbono, fundamentalmente debido al principio de Le Châtelier que favorece la transformación del $\mathrm{CO}_{2}$ a altas presiones.

En el Capítulo III, titulado "Enhanced light activation of the catalyst", se estudió la optimización de los resultados desde el punto de vista de la absorción de luz del catalizador. La síntesis de un catalizador que aumente la cantidad de luz absorbida en la franja del visible mejoraría la eficiencia del proceso fotocatalítico y la transformación del dióxido de carbono.

Para la síntesis del nuevo catalizador, el objetivo fue mejorar la deposición de las nanopartículas de cobre sobre la superficie de los nanorods de óxido de zinc, aumentando así la zona de contacto entre ambos materiales que es el centro activo para la hidrogenación del $\mathrm{CO}_{2}$. La síntesis de los nanorods de óxido de zinc se realizó del mismo modo que anteriormente, y se introdujo la hidracina como agente reductor para el cobre y mejorar su deposición. El principal punto del diseño del nuevo catalizador fue la cantidad de hidracina añadida, ya que se requería suficiente volumen para reducir completamente al cobre sin dañar los nanorods previamente sintetizados. 
Tras varios experimentos, se determinó que la cantidad idónea de hidracina correspondía a una proporción 3:1 de hidracina respecto al precursor de cobre utilizado (cloruro de cobre). Para esta cantidad, se analizó mediante Microscopía de Transmisión Electrónica el catalizador sintetizado (Figura 14).

En esta imagen se pudo comprobar que la cantidad de cobre depositada sobre la superficie de los nanorods de óxido de zinc fue considerablemente mayor que la lograda en el capítulo II, por lo que el primer objetivo a desarrollar fue cumplido.

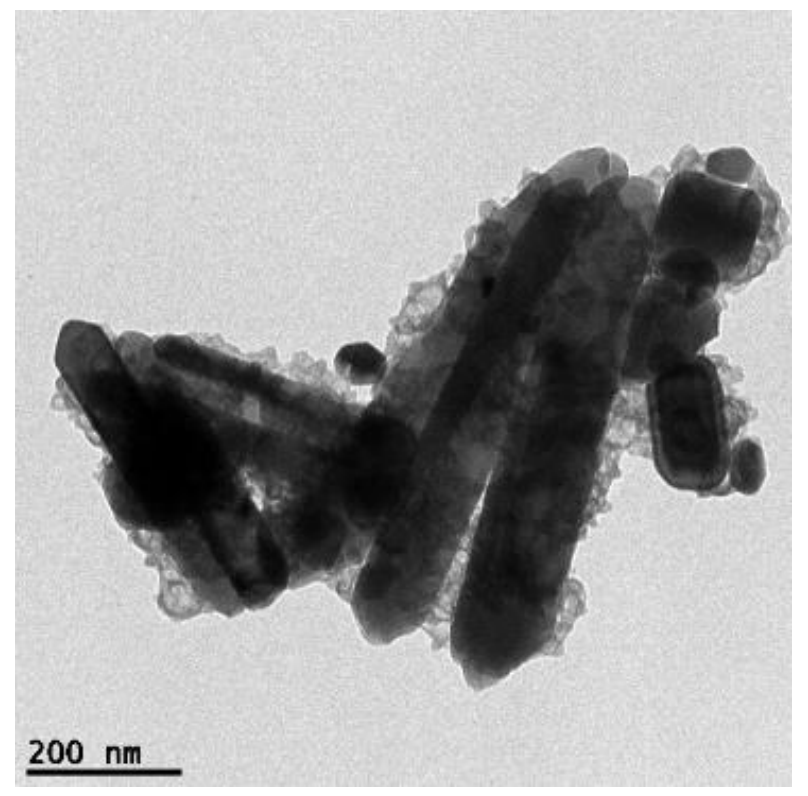

Figura 14. Imagen TEM del nuevo catalizador bimetálico $\mathrm{Cu} / \mathrm{ZnO}$ sintetizado.

Para comprobar que esta mayor cantidad de cobre depositada se correspondió con una mayor absorción de luz del catalizador, se utilizó la Espectrofotometría Ultravioleta - Visible (Figura 15). 


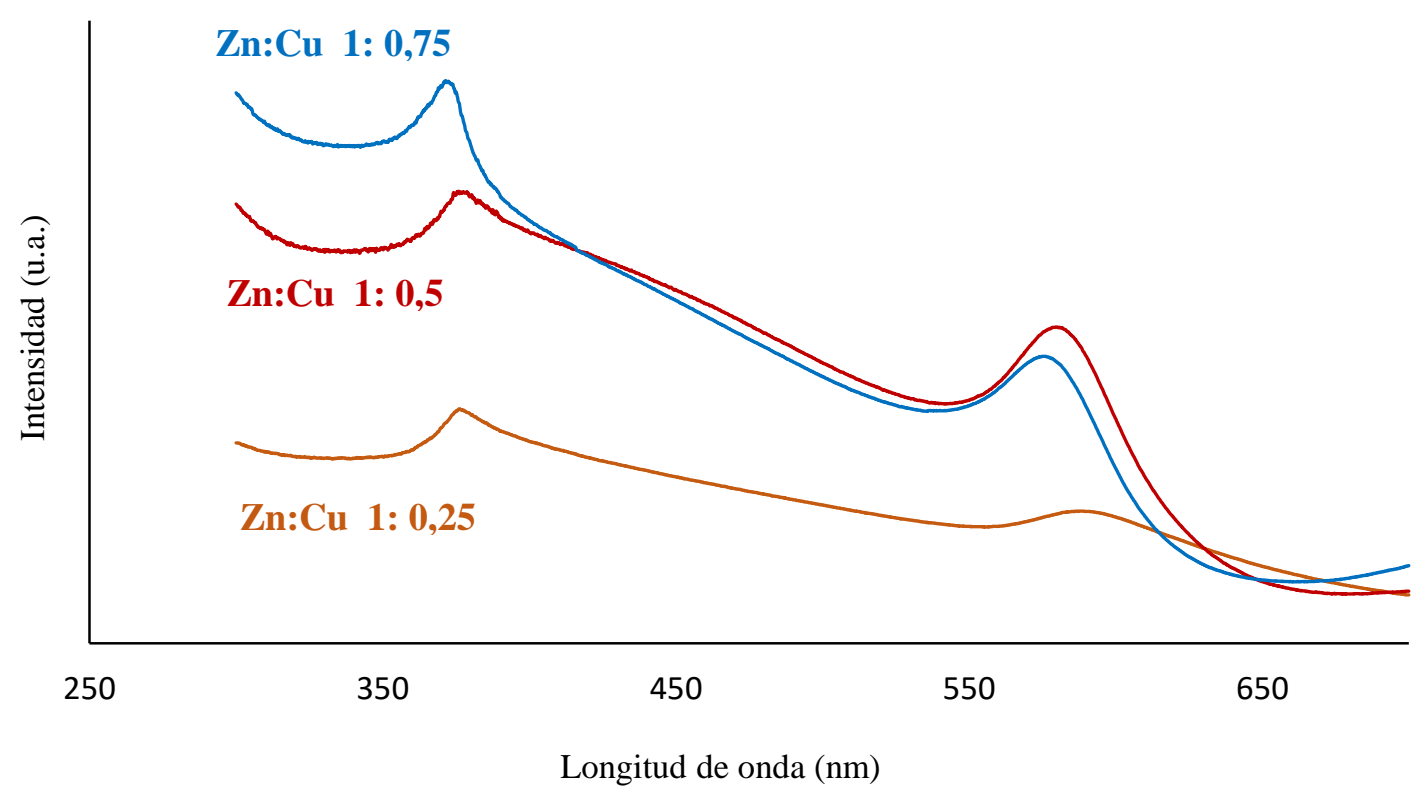

Figura 15. Espectro de absorción UV-Vis del catalizador bimetálico para una proporción 3:1 (Hidracina : Cobre).

En esta figura se apreció que la absorción de luz por parte del catalizador bimetálico se incrementó considerablemente, obteniéndose los mejores resultados para las proporciones 1:0,5 y 1:0,75 de zinc respecto al cobre añadido. Como la absorción de luz en el visible de las nanopartículas de cobre fue mayor para la proporción 1:0,5, ésta fue seleccionada como la relación óptima para sintetizar el nuevo catalizador y realizar la reacción de hidrogenación del dióxido de carbono con él.

Con el nuevo catalizador sintetizado se volvió a estudiar la influencia de los parámetros de operación en la conversión del $\mathrm{CO}_{2}$. Debido a que la presión fue identificada en el capítulo II como la variable clave para optimizar el proceso, se decidió estudiar solamente como influía esta variable con el nuevo catalizador. Con este propósito, experimentos a presiones de entre 20 y 100 bar fueron llevados a cabo. Para todas las experiencias la temperatura de trabajo fue $50{ }^{\circ} \mathrm{C}$, la cantidad de catalizador cargada en el aerogel fue de un $10 \%$ en peso, y el caudal de los gases 
de entrada fue de $1 \mathrm{ml} / \mathrm{min}$ para el $\mathrm{H}_{2}$ y $0,33 \mathrm{ml} / \mathrm{min}$ para el $\mathrm{CO}_{2}$. La corriente de salida fue analizada cada 10 min con el microcromatógrafo de gases para estudiar la transformación del $\mathrm{CO}_{2}$ (Figura 16).

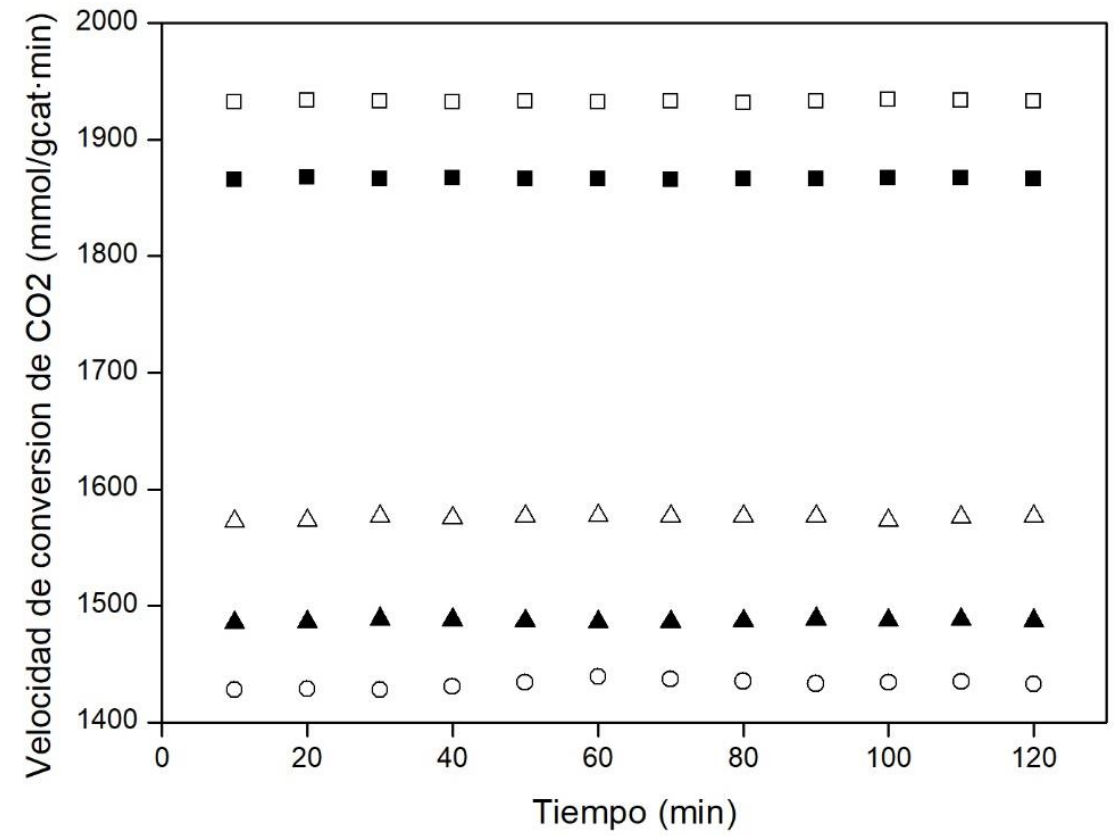

Figura 16. Influencia de la presión en la reacción $(20$ bar $\bigcirc, 30$ bar $\boldsymbol{\Lambda}$, 50 bar $\Delta$, 80 bar $\mathbf{m}$, 100 bar $\square)$.

Se pudo observar que la presión continuó aumentando la velocidad de conversión del $\mathrm{CO}_{2}$ también para el nuevo catalizador. Antes de alcanzar el punto crítico los resultados mejoraron $45 \mathrm{mmol} / \mathrm{g}_{\mathrm{cat}} \cdot \mathrm{min}$ cada $10 \mathrm{bar}$. Tras alcanzar condiciones supercríticas los resultados siguieron mejorando aunque el beneficio para la velocidad de conversión fue menor que en los casos anteriores. La mayor velocidad de conversión, obtenida para una presión de trabajo de 100 bar, permitió multiplicar por cuatro las velocidades obtenidas en el capítulo II.

\section{Conclusiones}

Esta investigación es una contribución a la lucha contra el efecto invernadero y el cambio climático generados por el aumento de las emisiones de dióxido de carbono. La 
hidrogenación de dióxido de carbono mediante energía lumínica ha sido propuesta como solución para transformar este gas evitando emitirlo a la atmósfera.

El novedoso concepto para realizar esta transformación ha sido explicado en esta tesis. La innovación más importante ha sido el diseño de un microreactor plasmónico que integra a la vez al catalizador y reactor como una sola entidad con una única respuesta a la luz. Ha sido la primera vez que un catalizador bimetálico de cobre y zinc comúnmente usado para la producción de metanol ha sido integrado en microreactores de vidrio usando la resonancia superficial de plasmones. La transmisión de la luz y la activación del nanocompuesto sintetizado han sido los aspectos fundamentales en el desarrollo de esta tesis.

Este trabajo ha sido dividido en tres capítulos en los que el desarrollo del dispositivo y la optimización del proceso han sido realizados. Las principales conclusiones obtenidas se muestran a continuación:

- Un catalizador capaz de absorber la luz en las bandas del visible y el ultravioleta ha sido sintetizado. Este catalizador consistió en nanopartículas de cobre depositadas sobre nanorods de óxido de zinc. La absorción de luz de este material ha sido estudiada mediante espectrofotometría ultravioleta-visible. Sin embargo, ha sido imposible caracterizar el catalizador tras producirse la reacción, lo que sería importante para poder entender el mecanismo de reacción y el papel que tiene el catalizador. Esto se debió fundamentalmente a la pequeña cantidad de catalizador usada en cada reacción, la cual no es suficiente para poder ser analizada mediante las técnicas de caracterización convencionales. Otras alternativas como el uso de un sincrotrón o la espectroscopia 
Raman in situ fueron estudiadas, aunque no fueron técnicamente viables para ser implementadas en este trabajo.

- El catalizador bimetálico sintetizado ha sido cargado en aerogeles de sílice mesoporosos alcanzando una carga máxima del $13 \%$ en masa. Los aerogeles de sílice fueron seleccionados como soporte debido a su alta transparencia y a las elevadas áreas superficiales que poseen y que permiten cargar gran cantidad de catalizador. El nanocompuesto desarrollado ha sido caracterizado mediante diferentes técnicas como la Microscopía de Transmisión Electrónica, la Espectroscopia Infrarroja por Transformadas de Fourier o el análisis BET de área superficial.

- La impregnación del catalizador en el interior de microreactores de vidrio con 0,5 mm de diámetro interno ha sido lograda aprovechando las propiedades de los hidrogeles. La técnica de impregnación desarrollada permitió distribuir el catalizador de forma homogénea a lo largo de toda la longitud del reactor $(15 \mathrm{~cm})$ y aseguró su llenado completo evitando espacios vacíos o burbujas de aire. Después del proceso de secado los aerogeles mostraron una gran adherencia a las paredes de los microcanales. El uso de microreactores permitió aumentar la eficiencia del proceso de iluminación.

- Una instalación experimental ha sido diseñada y construida para llevar a cabo la reacción. Esta planta experimental aseguró un control preciso de los gases de entrada y permitió trabajar a diferentes presiones y temperaturas para poder estudiar su influencia en la conversión del dióxido de carbono. La luz fue aportada por un conjunto de luces LED que fueron colocadas rodeando completamente al microreactor logrando así la mejor distribución de luz a lo largo de toda su longitud. Esta planta experimental permitió trabajar a presiones de hasta 100 bar, lo que representa una gran mejora si se compara con 
los 20 bar que es la presión máxima a la que trabajan otros autores que investigan la transformación fotocatalítica del dióxido de carbono. En este trabajo de investigación se alcanzaron por primera vez condiciones supercríticas para el dióxido de carbono trabajando con microreactores para la transformación en continuo del dióxido de carbono usando un catalizador plasmónico.

- Sin embargo, el microGC mostró problemas para medir la producción en continuo de metanol debido a la sensibilidad del equipo. La producción global de metanol obtenida estuvo en concordancia con la cantidad de dióxido de carbono transformada, aunque el metanol no fue medido de una forma continua y apareció en forma de pulsos periódicamente.

- La primera prueba de concepto realizada mostró que la hidrogenación de dióxido de carbono activada mediante luz pudo ser llevada a cabo con buenos resultados. Por primera vez se utilizó una estructura transparente para la transformación fotocatalítica del dióxido de carbono en un microreactor en continuo. Con esta prueba de concepto se demostró que la idea inicial propuesta era técnicamente viable y se abrió la posibilidad de continuar mejorando los resultados mediante la optimización del proceso.

- La optimización del proceso ha sido estudiada en dos direcciones diferentes:

- La influencia de los parámetros de reacción fue analizada con el objetivo de mejorar la velocidad de conversión del dióxido de carbono. Modificar la temperatura o la proporción de los gases de entrada no se tradujo en una mejora de la velocidad de conversión del dióxido de carbono, no siendo útiles para mejorar los resultados. Sin embargo, la mejora de la eficiencia del proceso desarrollado 
permitió trabajar a temperaturas de $50{ }^{\circ} \mathrm{C}$, lo cual supuso un beneficio comparado con las mayores temperaturas usadas en la producción convencional de metanol.

Aumentar la cantidad de catalizador fue negativa para el objetivo de mejorar la velocidad de conversión del dióxido de carbono, lográndose los mejores resultados para la menor cantidad de catalizador. Se ha demostrado que el parámetro clave para mejorar los resultados fue la presión. Aumentar la presión hasta 50 bar aumentó la velocidad de conversión considerablemente, aunque fue el paso a condiciones supercríticas del $\mathrm{CO}_{2}$ lo que multiplicó los beneficios en la velocidad de conversión obtenida Mientras que otros parámetros mejoraron ligeramente los resultados, la presión aumentó hasta en un 30\% la velocidad de conversión.

- Un nuevo método para reducir las nanoparticulas de cobre y depositarlas en los nanorods de óxido de zinc fue desarrollado. La hidracina fue seleccionada como agente redactor, controlándose la cantidad añadida con la finalidad de reducir completamente el cobre sin dañar los nanorods de óxido de zinc previamente sintetizados. El nuevo catalizador producido fue caracterizado mediante espectrofotometría ultravioleta - visible donde se observó un aumento de la luz absorbida por las nanopartículas de cobre alrededor de los $580 \mathrm{~nm}$. Este catalizador bimetálico fue cargado nuevamente en los aerogeles de sílice mesoporosos e impregnado en microreactores de vidrio para realizar la hidrogenación del dióxido de carbono. Un aumento de la presión continuó mejorando las velocidades de conversión obtenidas, especialmente trabajando en condiciones supercríticas. 


\section{ACKNOWLEDGMENTS}



Me gustaría comenzar los agradecimientos de esta tesis por María José Cocero que confió en mí y me dio la oportunidad de realizar este trabajo en el Grupo de Procesos a Alta Presión de la Universidad de Valladolid. Pero no quiero que sea un agradecimiento por compromiso, ya que además de haber decidido darme la oportunidad siempre ha estado disponible para ayudarme a pesar de no ser la directora de esta tesis. Siempre ha resuelto todas mis dudas en todos los temas administrativos (que se acercan a la mitad del trabajo de un doctorando) y siempre se ha mostrado preocupada con toda mi investigación y dispuesta a ayudarme siempre que lo necesitara. No tengo palabras para describir lo importante que ha sido para mí durante todo este tiempo y lo agradecido que le estoy por todo lo que ha hecho por mí.

En segundo lugar quería agradecer al ideólogo de esta tesis, Alexander Navarrete, que es quién tiene el mérito de haber pensado en la idea y de además haberse arriesgado a intentar llevarla a cabo. Ojalá hubiera más personas igual de comprometidas con la investigación como él. Gracias por todas las ideas proporcionadas, por toda la colaboración en el desarrollo de la investigación y por la disponibilidad para todas las consultas tanto aquí en Valladolid como posteriormente a distancia. Todo esto no habría sido posible sin ti. Y quería extender este agradecimiento a Ángel Martín, que también ha terminado realizando las labores de segundo director, ayudando en la corrección y estando igualmente disponible para colaborar. Gracias a los dos.

Igualmente importantes para este trabajo, quería acordarme de las personas que me dieron la oportunidad de acudir a sus centros de investigación para realizar parte de mi trabajo. En primer lugar, a Roland Dittmeyer que me abrió las puertas del Karlsruhe Institute of Technology y puso a mi disposición todos los recursos de su departamento; y a Jürgen J. Bradner por haber sido mi tutor en mis tres meses allí colaborando en mi trabajo. Y quiero agradecer a mis compañeros de departamento en aquellos meses, en especial a Felix y 
Kay por su cálida acogida y por todos los buenos momentos que pasamos en aquel tiempo. Sigo conservando un gran recuerdo de aquellos días. Y en segundo lugar, a Marek Grzelczak por haber querido colaborar con esta investigación y haberme dado la oportunidad de haber estado en el CICbiomagune de San Sebastián. Allí aprendí muchas cosas que han sido básicas para poder terminar esta investigación, todo ello gracias a Ana Sánchez Iglesias que tanto me enseñó y que tan duro trabajó conmigo para sacar todos los resultados posibles en tan poco tiempo. Gracias Ana por haber trabajado tanto por ayudarme.

El agradecimiento más importante de la tesis quiero que sea para la MacGyver del laboratorio, que con un chicle sería capaz de arreglar una fuga a más de 100 bar. Siempre con la actitud más colaborativa que yo haya visto en nadie, siempre aportando ideas y siempre dispuesta a hacer todo lo necesario para que todo funcione. Sabe de todo, puede con todo, y no hay nada imposible para ella y para su imaginación. Desde el momento en el que llegó al laboratorio se notó como todo iba a mejor, y desde entonces es imprescindible su presencia para que todo funcione como debe. Gracias Isa por haber hecho tanto por mí, y haberlo hecho siempre con una sonrisa y con la mejor disposición. Te estaré eternamente agradecido, ojalá algún día vuelva a tener algún compañero de trabajo como tú. No quiero olvidarme de sus subordinados, Sergio y Alvar, que en diferentes momentos también han contribuido a esta tesis mostrándose igualmente siempre dispuestos para ayudar y realizando un gran trabajo. Quiero extender este agradecimiento a otros técnicos del departamento que también me han ayudado como Dani, Miguel Ángel y Enrique. Gracias a todos.

A continuación, el siguiente agradecimiento es para mi mentor en el mundo de los aerogeles y que tantas cosas me enseñó en mis comienzos en el laboratorio. Gracias al Doctor Jefe Empresario Luis Miguel Sanz por todos los conocimientos que me transmitió, 
por todas las ideas que siempre ha aportado para esta tesis y por su generosa colaboración. Menos mal que lo necesité antes de que estuviera todo el día recibiendo premios, no sé si después habría tenido tiempo para mí.

Después, quiero agradecer a Celia toda su colaboración y todo su tiempo en los comienzos de la tesis. Tener una persona a mi lado que se preocupara siempre por mis problemas y que se sentara conmigo a analizar las cosas fue muy importante para mí, aunque fuera de un tema de investigación totalmente diferente al suyo. Gracias por haber contribuido durante mucho tiempo y por haberte preocupado sinceramente de que me fuera lo mejor posible.

El siguiente agradecimiento quiero que sea compartido, porque sé que a ellos les gusta ir siempre juntos incluso en los agradecimientos. Quiero agradecer a Alberto y a Marta su ayuda en todo el trabajo de laboratorio y sus consejos e ideas para llevar a cabo la tesis. Además de todos los momentos vividos juntos, su experiencia previa en el laboratorio me ha servido mucho y les estoy muy agradecido. Alberto siempre me ha ayudado con los temas de catálisis con la mejor de las actitudes, y Marta, aunque con su carácter de Valladolid, también ha colaborado y me ha ayudado mucho.

Y por último, dentro de los agradecimientos personalizados, quiero agradecer a Vito por toda su paciencia en todo este tiempo final de escritura, por todos sus consejos y correcciones para que esta redacción haya quedado lo mejor posible. Has sido muy importante para mí dentro y fuera del trabajo, y lo mejor y más especial que me ha dado mi vida en Valladolid. Gracias por ser la mejor compañía y por todos los buenos momentos a tu lado. 
También quiero agradecer a muchas más personas que han sido importantes en mi vida y trabajo en Valladolid y que son algo maravilloso que me llevo de todo este tiempo. Quiero agradecer primero a Gyuri, básicamente porque si no lo nombro el primero sé que se va a enfadar. Y porque fue mi primer amigo aquí y cada vez que nos reencontramos es una alegría enorme para mí. A Reinal y a Adri por todos los momentos de desconexión de la tesis y los buenos recuerdos juntos. A María y Tijuana por compartir mis últimos tiempos de la tesis y haberme ayudado a sobrellevarla. Y al resto de mis compañeros del grupo de procesos a alta presión y a Diego, que durante una temporada molestó mucho pero también ha contribuido a este trabajo. Y aunque no sean del mismo grupo, a mis amigas Judit y Ana que sé que también se alegran de que haya llegado hasta aquí.

Y aunque haya compartido menos tiempo con ellos, lo bueno de la tesis es que conoces a muchísimas personas que aunque vengan por periodos reducidos, a veces es suficiente para que dejen huella en ti. Por eso me quiero acordar también de María José, Inés y Vanessa, porque las sigo recordando con mucho cariño y haber estado en sus ciudades o incluso bodas después de mucho tiempo sin vernos muestra lo importantes que siguen siendo para mí. Me quiero acordar también de Gerardo, Agostinho y Sebastiano que tampoco estuvieron mucho tiempo pero que igualmente son amigos y espero que podamos reencontrarnos muchas veces en el futuro.

Y fuera de las personas que he conocido en Valladolid, quiero agradecer por supuesto a mi familia que son la base para que yo pueda estar hoy aquí. Tanto mis padres como mi hermana son fundamentales y su apoyo siempre ha sido necesario para poder conseguir este objetivo. Espero que puedan sentirse orgullosos de que haya llegado a ser doctor. Al igual que el resto de mi familia y de todos mis amigos que sé que hoy están contentos de que haya llegado hasta aquí. Gracias a todos. 
ABOUT THE AUTHOR 



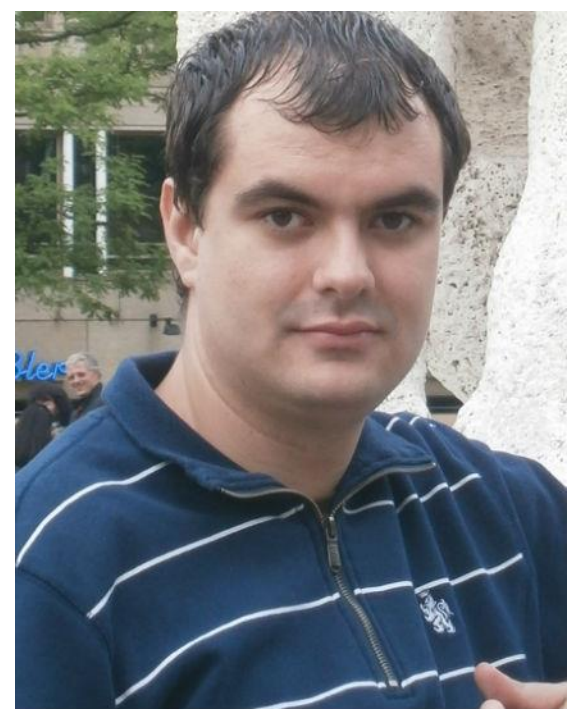

Sergio Muñoz Palacios was born in Ciudad Real in 1988. He studied Chemical Engineering at University of Castilla -La Mancha and finished his studies in 2011. In 2010 he made an internship at Repsol's refinery in Puertollano. In 2012, he obtained a Master's degree in Business Administration and Engineering of the Organization and started to work at Empresa Municipal de Transportes de Madrid.

He also worked at UNED and a logistic company in Madrid before starting to work at University of Valladolid in 2013. During his first year, he began a Master's degree on Research in Fluid Thermodynamics Engineering and started to work at the High Pressure Processes Group from University of Valladolid. In 2014, he started his PhD studies in the same group, under the supervision of Alexander Navarrete and Ángel Martín.

His research has been focused on the photocatalytic transformation of carbon dioxide by means of renewable energies, working in the development of new materials that can be activated by light energy. His $\mathrm{PhD}$ thesis is called "Carbon dioxide hydrogenation by means of plasmonic resonance activation". 


\section{$\underline{\text { List of publications and communications }}$}

\section{Publications}

- $\quad$ Navarrete, A., Munoz, S., Sanz-Moral, L.M., Brandner, J., Pfiefer, P., Martín, A., Dittmeyer, R., Cocero, M.J., Novel windows for "solar commodities": a device for $\mathrm{CO}_{2}$ reduction using plasmonic catalyst activation. Faraday Discussions, 2015, Vol. 183, p. 249.

- Muñoz, S., Navarrete, A., Sanz-Moral, L.M., Brandner, J., Pfiefer, P., Martín, A., Dittmeyer, R., Cocero, M.J., Carbon dioxide hydrogenation by means of plasmonic resonance activation. 22nd International Congress of Chemical and Process Engineering, CHISA 2016 and 19th Conference on Process Integration, Modelling and Optimisation for Energy Saving and Pollution Reduction, PRES 2016. Vol. 2, pp. 891-892.

- Muñoz, S., Navarrete, A., Martín, A., Cocero, M.J., Carbon dioxide hydrogenation by means of plasmonic resonance activation in Silica Aerogel Media (Submitted).

- Muñoz, S., Navarrete, A., Grzelczak, M., Sánchez-Iglesias, A., Martín, A., Cocero, M.J., Enhanced light activation of copper / zinc oxide catalysts impregnated in silica aerogels to perform carbon dioxide hydrogenation (Submitted).

\section{Communications}

- Nanosciences Ile-de-France, organized by the Centre National de la Recherche Scientifique (CNRS). Poster communication. June 2015, Paris, France.

- VIII Reunión de Expertos en Tecnologías de Fluidos Comprimidos. Poster communication: "Conversion of carbon dioxide into solar fuels by means of plasmonic catalyst activation”. September 2015, Cádiz, Spain. 
- II Encuentro de Jóvenes Investigadores de la Sociedad Española de Catálisis. Oral and poster communication "Hidrogenación de dióxido de carbono mediante activación por resonancia de plasmones”. June 2016, Ciudad Real, Spain.

- 22th International Congress of Chemical and Process Engineering CHISA 2016. Oral presentation "Carbon dioxide hydrogenation by means of plasmonic resonance activation”. August 2016, Prague, Czech Republic.

- 16th European Meeting on Supercritical Fluids, organized by the International Society for Advancement of Supercritical Fluids. Oral presentation "Carbon Dioxide Hydrogenation by Means of Plasmonic Resonance Activation”. April 2017, Lisbon, Portugal.

- Congreso "Aportando valor al $\mathrm{CO}_{2}$ ", organized by Plataforma Tecnológica Española del $\mathrm{CO}_{2}$ y SusChem-España. Poster communication. May 2017, Tarragona, Spain.

\section{Predoctoral stays}

- 3 months research stay at Institut für Mikroverfahrenstechnik (IMVT) from Karlsruhe Institut of Technology (Karlsruhe, Germany). September - December 2015.

- Short stay at CIC biomagune, Research Center located in San Sebastián, País Vasco. November 2016.

\section{PhD Grants}

- Contrato Predoctoral de la Universidad de Valladolid, convocatoria del año 2016 (Cofinanciados por el Banco Santander). 
- Ayuda para estancias breves en el desarrollo de tesis doctorales, convocatoria año 2015, concedida por la Universidad de Valladolid.

- Ayudas para la asistencia a cursos, congresos y jornadas relevantes para el desarrollo de tesis doctorales, convocatorias de los años 2016 y 2017, concedidas por la Universidad de Valladolid. 

